\title{
Introduction: A Guide to Sade's Grand Tour of Italy and the Road to Infamy
}

In the summer of 1775, Donatien Alphonse François, Marquis de Sade (1740-1814), having just turned thirty-five, set off for Italy. It could not be said that, at the time of this trip, Sade's reputation was one of a wholesome paragon of aristocratic virtue, though he had not yet set his quill to those depictions of obscene excess and bloody debauchery that were to make his name a byword for pleasure in malice. Instead, our marquis was imagining for himself a legitimate career as a man of letters. This was a dream Sade nourished early on and never fully relinquished, as witnessed, above all, by his numerous theatrical pieces comedies, tragedies, and the mixed form that went simply by the name drame - penned starting around 1770 and through his final years. Most of these works went unperformed, except for Sade's three-act drama Le Comte Oxtiern, ou Les Dangers du libertinage (Count Oxtiern, or the dangers of libertinism), which did enjoy limited success in 1791 at the Théâtre de Molière. ${ }^{1}$ Stage pretensions aside, Sade determined, pretty much from the start of his trip to Italy, to pursue his literary aspirations by producing a guidebook for others travelling to that country, whether actually or virtually via the printed word, and he put an astonishing amount of effort into this endeavour. It did not, however, make it to the presses in his lifetime. Sade's Italian project appeared in print only more than a hundred and fifty years after his death, with the 1967 publication of his Voyage d'Italie, edited by Gilbert Lely and Georges Daumas. A second, more comprehensive transcription, edited by Maurice Lever, was published in $1995 .{ }^{2}$ Journey to Italy is the first-ever appearance in English of Sade's entire Italian project. This work is a fascinating window on attitudes to travel, tourism, science, art (especially painting and architecture), culture, politics, religion, sex, and just about anything else in late eighteenth-century Europe. Emphatically, Sade's Journey to Italy is essential to understanding the author's path to his lasting notoriety.

A major landmark on that route is often dated to 1785 , or some ten years after the Italian trip, when Sade penned the first and truly shocking work of his clandestine oeuvre: Les 120 journées de Sodome (The 120 Days of Sodom). He wrote this while in his cell in the Bastille, that famous prison where the French kings incarcerated personages accused of various, sometimes egregious and sometimes apparently innocuous offences. ${ }^{3}$ Sade would lose track of this manuscript when, to keep him from stirring up trouble, he was abruptly transferred to the mental asylum at Charenton. A few days later, on the afternoon of 14 July 
1789, a crowd of Parisians famously stormed the Bastille, thus marking the beginning of the French Revolution. Written on a makeshift scroll in a miniscule hand, the manuscript somehow survived, though Sade would die unaware of its fate. Like Sade's Italian project, this tale, in which four repugnant libertines orchestrate and enact a panoply of passions classed as simple, complex, criminal, and murderous - would not be published until the twentieth century. In the twenty-first, this scroll on which Sade penned Les 120 journées de Sodome would be declared an unlikely "national treasure." ${ }^{4}$ Explicit, repeated descriptions of rape and coprophagy do not usually qualify as content for such an honour.

While in the Bastille, in 1787, Sade also drafted the manuscript for Les Infortunes de la vertu (The Misfortunes of Virtue), ${ }^{5}$ the story of a young woman, orphaned and forced on a picaresque voyage during which she is betrayed and brutalized at every turn. It was the kernel of Sade's first libertine novel that would see publication (anonymously, of course) and one that immediately gained a scandalous reputation: Justine, ou les Malheurs de la vertu (Justine, or the Misfortunes of Virtue). ${ }^{6}$ This was in 1791, not long after now citizen Sade was released from more than a decade of incarceration. He had been held at the behest of the présidente de Montreuil - Sade's mother-in-law - by a lettre de cachet, a device by which the monarch could order detention without trial. If French revolutionaries often had little patience for $c i$-devant aristocrats, they had less love still for this despised abuse by the Ancien Régime. In his days of freedom, Sade expanded his narrative once again, including episodes in Italy, in his unimaginatively titled La Nouvelle Justine (The new Justine). In a sequel, L'Histoire de Juliette, ou les Prosperités du vice (The story of Juliette, or the boons of vice) (1797-1801), the perpetual victim's lubricious, wicked sister flourishes while cutting a swath of destruction across Europe. ${ }^{7}$ A substantial portion of this sequel, too, takes place in Italy, with the eponymous heroine largely following the route that Sade had taken over twenty years before. That his trip to Italy and the writing project associated with it were somehow formative for Sade and his clandestine literary career would seem to be beyond doubt. Exactly how is less obvious, though this introduction should go some way in providing a detailed answer.

On the face of it, there was nothing unusual about Sade's Italian journey, which lasted from July of 1775 into the following June, or nearly a year. Sade was a relatively young man at the time, from a titled, well-established, and respectable Provençal family. ${ }^{8}$ Making such a trip would have been almost expected of him. The so-called grand tour developed in the seventeenth century as a rite of passage for aristocratic men. It was, to be sure, an expensive and time-consuming operation, undertaken by coach and usually with an entourage including a tutor and valets, at a minimum. ${ }^{9}$ The average rate of progress, leaving some time for sightseeing, was about ten leagues, or thirty miles in a day, slower in mountainous regions and depending on the weather. ${ }^{10}$ Costs included not only lodging and meals but also frequent tolls and customs. Brigandage could be a problem in some areas. In addition to money and caution, to come off smoothly the grand tour required letters of recommendation. These would open the doors of private houses, help provide access to luminaries, and ease entry into foreign upper-class society. Travel was intended to cultivate a gentleman's taste in the fine arts, instil a deeper appreciation of history, enable encounters with eminent minds, and develop a cosmopolitan spirit. The grand tour was a British practice at the outset, but it did not take long for the French aristocracy to follow suit. Further, while the tour was originally broadly Continental, the focus of grand tourists soon became Italy. Not a nation in political terms but rather a congeries of states at this point, Italy was nonetheless deemed a cultural whole. Italy was the very heart of what was understood to be 
the restoration in Europe of the arts and knowledge more broadly after the fall of Constantinople to the Ottomans and the definitive end of the Byzantine Empire in the mid-fifteenth century. In Italy remnants of Antiquity could be found in profusion: mementos of republican virtue, monuments of Imperial glory, and ruins that silently, solemnly announced the inevitability of decline and decay. There were operas, too, along with gaming, masked balls, and intrigues. Not all grand tourists fulfilled in practice the lofty goals that motivated their travel in theory: binge drinking, vandalism, and sex tourism are hardly recent inventions. The Marquis de Sade's comportment en route was not impeccable, but it was also fairly typical. His curiosity and engagement appear to have been sincere, notwithstanding his frequent scepticism about perceived Italian zealotry.

Like many before and after him, Sade found in Italy ample evidence of praiseworthy achievements as well as historical episodes and contemporary customs ripe for cynical asides and supercilious ridicule. Unlike others, Sade could also claim an unusual family connection to the region: Laura de Noves (1310-1348), the muse of Francesco Petrarch's Canzoniere, was the wife of his ancestor Hugues de Sade. This, at least according to the case made by Donatien's uncle and childhood instructor, Jacques-François Paul Aldonse de Sade, and not without evidence and logic, in his three-volume biography of the poet entitled Mémoires pour la vie de François Pétrarque (Memoirs on the life of Francesco Petrarch) of 1764 . Who Laura really was - or whether she was simply an ideal to which the poet had put a name - is altogether another matter. ${ }^{11}$ Sade's uncle, in any case, was a high-ranking cleric of Epicurean bent, and whether he cultivated his nephew's nascent libertinism has long been a matter of speculation. He would certainly have taught his charge the importance of this family connection to the peninsula. Yet we must bear in mind that neither Sade's purported link to the most celebrated woman in Italian literary history, barring Dante's Beatrice, nor even a broader interest in Italian art, history, and culture were the immediate motivations of Sade's journey: simply put, the Marquis de Sade was on the run.

By the summer of 1775 , Sade was no stranger to legal proceedings and a policing apparatus increasingly interested in cases of aristocratic malfeasance that previously would have elicited a shrug. In his twenties, the marquis had drawn the attention of the authorities through, among other things, violent behaviour directed at prostitutes. The first significant incident came more than a decade earlier (in 1763), when Sade engaged Jeanne Testard, a fan maker and occasional prostitute, for a session of blasphemous readings and activities. The latter included Sade masturbating on a figure of Christ. Testard apparently refused to whip or be whipped, turned down an enema, would not trample a crucifix, and rejected Sade's sodomitical advances. She also immediately went to Antoine de Sartine, lieutenant general of the Paris police from 1759 to 1774, and reported her experience. The case that followed introduced Sade to a certain Inspector Louis Marais, in charge of the Paris vice squad and taxed with keeping tabs on wayward nobles. It also led to Sade's first short stint (several days) in prison. Thanks to his family connections, reports of the case were muted and his punishment mitigated. Such was not to be five years later, when the next scandal erupted. On 3 April 1768, Sade secured the services of a woman named Rose Keller. The exact terms of her employment remain unclear, though the young man's general intent is easy enough to divine. Keller was Alsatian, thirty-six years old, recently widowed, and of humble means at the best of times. That Easter Sunday when Sade encountered her in Paris, she was begging, soliciting, or perhaps both. He took Keller to the suburb of Arcueil, where he kept a petite maison. Literally, a "small house," these were common among aristocratic men. They were used for entertainment and enabled concealment. We will never know 
precisely what happened in that petite maison in Arcueil, but the likeliest scenario is that Sade restrained Keller and whipped her until she bled. She claimed more insidious treatment still, involving deliberate incisions and hot wax dripped on her wounds. Sade claimed he applied an unguent. Keller managed to escape and alert the authorities. An already lurid affair grew in the retelling, with Sade eventually portrayed as attempting human vivisection out of inhuman curiosity. ${ }^{12}$ This was surely nonsense. Be that as it may, Sade did discover that paying off his victim and aristocratic privilege were now insufficient guarantees of freedom. He was to spend several months imprisoned in the Château de Pierre Encise, a fortress near Lyon.

The subsequent major scandal was in 1772 and more sordid still. In Marseilles, on the morning of 27 June, Sade engaged four prostitutes. ${ }^{13}$ According to testimony from the eventual legal case against him, the women were first encouraged to consume some anise candies. These likely contained Spanish fly or cantharides, derived from blister beetles. Of long repute as an aphrodisiac for men, cantharides stimulates the urethra when excreted. It is also dangerously toxic. Latour, Sade's valet, provided the women with the rather odd explanation that these confections would produce flatulence and that his master would "take the wind in his mouth." 14 Only one of the prostitutes, a Marianne Laverne, consumed the candies. She quickly became ill, although not before whipping the willing Sade on the backside with both a parchment scroll studded with nails and a heather broom. She rejected the proposal, accompanied by monetary incentive, that either he or Latour sodomize her. With Marianne indisposed, Sade turned his attentions to Mariette Borelly. He thrashed her with the broom, and she returned the treatment. He then engaged in intercourse with her while masturbating his valet, who subsequently sodomized him. After this episode, Sade moved on to Rose Coste. The broom was put to work again, while master and servant engaged in manual stimulation. Rose refused a louis d'or to allow either man to sodomize her. Next came Marianne Laugier, known as Mariannette. When the marquis announced his intention to lash her, she noticed the bloodied parchment with nails. She tried to flee but was detained. The other Marianne was then brought into the room. Both women were again offered the pastilles. Laverne, suffering from her initial ingestion, demurred. Marianette initially capitulated, but she spat the candies out immediately. Sade whipped both women with the heather broom. He threw Laverne on the bed, exposed her buttocks, and placed his nose to her rear. The other woman was ordered to approach and to observe. Finally, Sade lay on Laverne's backside, perhaps sodomizing her, while Latour sodomized him. These were approximately the morning's activities. Later that evening, Sade engaged another prostitute. Her name was Marguerite Coste. He fed her several of the pastilles, performed anilingus on her, ordered her to break wind in his mouth, and proposed to take her from behind and in a variety of other ways. She consented only to treatment in accordance with "natural laws." ${ }^{15}$ She also became seriously ill and was treated for poisoning. It was Marguerite Coste who would set in motion the minions of the law, thus bringing to light the business of that entire June day.

Sade fled Marseilles for La Coste, his chateau in the nearby Ventoux. It soon became clear that he was no longer safe in France. He escaped to Italy, travelling as the Count of Mazan, one of his hereditary titles. After a police investigation, Sade was tried in absentia and convicted of poisoning and sodomy. The sentence handed down by the High Court of Provence, on 11 September 1772, was that Sade and his accommodating valet would first make an amende honorable or public act of contrition before the Cathedral of SainteMarie-Majeure in Marseilles: begging pardon of "God, the King, and justice" on their 
knees, wearing nothing but long shirts, barefoot and bare-headed, yellow-wax torches in each hand, and led by the executioner with a rope around their necks. The marquis was condemned to be beheaded; Latour to be hanged and strangled. The two would then both be burned, a traditional punishment recalling the fiery destruction of Sodom, and their ashes "thrown to the wind." ${ }^{16}$ Bathetically, both men were also fined. In the end, the executions took place in effigy in a public square in Aix.

It seems that the biggest miscalculation that Sade made was less what transpired in Marseilles - as an aristocrat he was an unlikely candidate for actual execution even given the more stringent policing - but rather, further alienating his in-laws, who were growing understandably tired of having their reputation besmirched. His choice of travelling companions for the impromptu Italian holiday only made matters worse, for he took with him his sister-in-law Anne-Prospère de Launay, a canoness at the time. ${ }^{17}$ Although Sade's wife, Renée-Pélagie de Montreuil, seems to have eventually forgiven him this and various other transgressions, he had, unsurprisingly, managed to gain the unwavering enmity of his mother-in-law. The details of Sade's movements at this point in Italy are not entirely clear, although he would later refer in his correspondence to his journey to Venice in the company of Mademoiselle Launay. At some point, the pair split up, apparently not amicably. The sister-in-law returned to La Coste. Sade took a boat from Genoa to Marseilles, where he collected some cash, moved on to Turin, and then to Chambéry, capital of the Duchy of Savoy, at the time part of the Kingdom of Sardinia. He had settled close to the city, but having unwisely revealed to his mother-in-law his whereabouts, he was ambushed by order of the king, whom Madame de Montreuil had urged to action. He was imprisoned in the nearby Fortress of Miolans, managed to escape, and spent the next several years as a fugitive.

For much of this time, our marquis was not in hiding but enjoying the comforts of La Coste, his chateau. Occasionally, he did have to take evasive action. This included a second trip to Italy, begun in March of 1774, cut short when he thought himself recognized by the French consul in Florence. ${ }^{18}$ He was back in France by June. Finally, it was Sade's insistence on holding orgies at La Coste involving jeunes filles or "young girls" from the vicinity that reignited the interest of the authorities and precipitated Sade's third, and final flight to Italy, in 1775. Again, he adopted his semi-incognito title, but now the Count of Mazan was accompanied not by a comely in-law but only by a valet named Carteron, known as La Jeunesse, and by Louis Charvin, the postmaster of Courthézon in the Vaucluse. Moreover, he now formulated his plan to write a book based on his tour. Sade would continue to work on this project after he had returned to France and was apprehended once again, in 1777, and locked up in the Château de Vincennes, a prison in the Parisian suburbs. He briefly escaped in 1784, was reapprehended, and then placed in the Bastille. There he would stay until the French Revolution temporarily secured his liberty. In late 1793, Sade was incarcerated as a moderate, but released a year later. In 1801, however, Napoleon ordered him detained once more, ostensibly for his libertine writings. Donatien Alphonse François, Marquis de Sade, would remain a prisoner until his death in 1814.

At the time of Sade's final journey to Italy, he was clearly a libertine in lifestyle. He was committed to sexual licence and considered morality to be, at best, polite convention. We should perhaps bear in mind, however, that Sade's views and much of his behaviour did not set him apart from fellow aristocratic debauchees and adherents of studied hedonism in his day. Erotic flagellation was a standard part of the libertine repertoire. The titillating effects of the whip had long been remarked, and they featured in seventeenth-century obscene writings such as Aloisiae Sigaeae, Toletanae, Satyra sotadica de arcanis Amoris et Veneris 
(Luisa Sigea of Toledo's sotadical satire on the secrets of love and venery) (1660) by Nicolas Chorier (1612-1692) and (at times loosely) translated into French as L'Académie des dames (The ladies' academy; 1680), as well as the pseudonymous abbé du Prat's Vénus dans le cloitre (1683) (Venus in the Cloister). ${ }^{19}$ An early English translation of the latter explains the contrary effect of punishing a certain nun: "She found by Experience, that these Whippings and Flagellations of her Posteriors, rather augmented than diminished her Fire; a rather silly and ineffectual Remedy then against Concupiscence." 20 That the person doing the whipping might also experience a certain frisson in inflicting pain was not lost on these writers either. Flagellation was common in the sex trade, and brothels were well stocked with implements meant to kindle languishing libidos. ${ }^{21}$ Sade does appear to have pushed the purported pleasures of giving and receiving the whip or similar instrument into dangerous territory. Acts of violence committed against prostitutes were, however, frequent. Finally, while the pleasures of sodomy, especially male penetration of women, are frequently praised in the radical reaches of licentious literature, significant penal risks discouraged (albeit by no means entirely curtailed) participation. Nevertheless, Sade's obsession with things anal in excess of intercourse certainly appears markedly strange. A hallmark of his mature libertine writings, this obsession was evidently already with him at the time of his evening with Jeanne Testard and later the affaire de Marseilles.

Still, to label Sade a sadist at the time that he departed for his last and most comprehensive Italian voyage is somewhat misleading, and not merely qua anachronism. We would have to emphasize the psychologically essential aspects of that category to which (in the twentieth century) he eventually lent his name. But in its original instance sadism, if you will, is not only or not simply a psychological profile and accompanying set of practices. Taking a socio-historical perspective, in eighteenth-century France libertinism was a lifestyle that one could - and Sade most certainly did - choose to follow. By his day, libertinism was informed by philosophical materialism and atheism. Finally, it was also an established genre of satirical and erotic writing. Sade married lifestyle, philosophy, and literary genre to his idiosyncratic personality and to his experiences, and we might say that sadism in its historical particularity names Sade's libertine writings, encompassing the works penned in the Bastille and afterwards. To reach that point, however, we must pass through Italy, all the while being mindful of why Sade was there in the first place, what he encountered, and what he was reading both during and after his trip, as he continued to work on his Italian manuscript. This manuscript drew extensively on myriad literary, historical, and experiential influences, and it was these that Sade would eventually weaponize in forging a libertine oeuvre at once both sui generis and traceable in its components. Those components are by and large present in the Journey to Italy: they are to be found in the portions of the work that Sade considered more or less complete and also in his various plans and sketches that were never finished or integrated into a work that, with apparent reluctance, Sade eventually abandoned. This is not to suggest some necessity or teleology. On the contrary, to follow Sade's route through Italy is to witness an accumulation of contingencies that, interacting and conditioned by both internal and external forces, would one day coalesce and congeal.

\section{On the Road}

The Marquis de Sade's grand tour started with a passage through the Alps at Mongenèvre, into the Piedmont and the territory of the Kingdom of Sardinia. The first city of consequence that he reached but spent little time in was Turin, a city that he would tersely 
characterize in Juliette as "the most regularly laid out and the most boring" in all of Italy. ${ }^{22}$ The Count of Mazan would likewise hurry through Asti, Piacenza, Parma, Modena, and Bologna on his way to Florence, capital of the Grand Duchy of Tuscany, where he arrived in early August 1775, and where he would remain for some two and a half months. Sade's main contact and guide in Florence would be Barthélemy Mesny, a Frenchman resident in the city, physician to the court, and deeply learned in natural history. As for Sade's principal misbehaviour during his Italian sojourn, it was seducing one of Mesny's daughters, Chiara Moldetti. Signora Moldetti was thirty years old, a mother of five, and pregnant at the time of Sade's visit. She would give birth to a daughter in late December or early January 1776. Sade seems to have charmed the whole family and was even chosen to be the baby's godfather. He missed the christening, however, and bypassed Florence on his return trip, presumably to avoid a rencontre with the mother. Letters from an increasingly distraught Moldetti, realizing she had been abandoned, as well as from her apparently unsuspecting father, are among the correspondence related to Sade's Italian journey, gathered in the last chapter of this volume. ${ }^{23}$

In Florence, Sade would also make the acquaintance of another French compatriot resident in Italy: the well-travelled and prolific hack writer Pierre Ange Goudar (1708-1791). ${ }^{24}$ Goudar was an erstwhile companion of Giacomo Girolamo Casanova (1725-1798), recently resettled in his home town of Venice after many peripatetic years. Like Sade, Casanova drew the attention of the authorities, spent time in prison, in his case for debt and for irreligion, a charge related to his favourite activities. In 1756, he famously escaped from his cell in the Piombi, a prison in the Doge's Palace in Venice. ${ }^{25}$ Goudar and Casanova had consorted in London, where the latter had his eyes on a young Irish barwoman named Sarah. In this instance, Casanova failed the seduction thanks to his companion, who had plans of his own for her. Sarah, also found as Sara (dates uncertain), became Goudar's wife, either legally or in name, and followed him to the Continent for various adventures and misadventures. These included, among others, a precipitous expulsion from Naples in 1774, ostensibly on the grounds of Ange Goudar's critical assessment in his book Naples: Ce qu'il faut faire pour rendre ce royaume florissant (Naples, what must be done to make this kingdom flourish), published some five years earlier. More likely, however, it was because of Maria Carolina's jealousy over an affair that her husband, King Ferdinand, was carrying on with Madame Goudar. In any event, the circumstances remain somewhat murky. Neither the monarch nor his spouse were known for their fidelity, and Maria Carolina may, in fact, have feared that Sarah was a conduit for influencing the king politically more than she resented her apparent seduction. ${ }^{26}$ Sade made Sarah's acquaintance, too, in Florence, where she - but in actuality Ange, using her as a cover for his prolixity was busy reporting in print on the season's theatre and other entertainments. ${ }^{27}$ The two may have had a brief dalliance, and certainly both were experienced in the genre. ${ }^{28}$ In Florence, Sade would also meet Pierre-François Hugues, self-styled Baron d'Hancarville (1719-1805), another opportunist and an antiquarian with a predilection for the erotic and obscene. D'Hancarville had worked with Sir William Hamilton (1730-1803), the English envoy to the Kingdom of Naples, to catalogue and describe the latter's horde of vases and other rarities, published in 1766-1767 in four volumes, with English and French on facing pages, as Collection of Etruscan, Greek and Roman Antiquities from the Cabinet of the Honble. Wm. Hamilton. The antiquities themselves were purchased in 1772 by the British Museum, founded by an act of Parliament in 1753, and the Hamilton acquisition constituted a key part of its early collection. 
Sade left Florence on 21 October 1775 and began the descent to Rome, stopping in Siena, passing through the heart of the Tuscan wine country, and arriving in the capital of the Papal States on the morning of the 27th. Through Doctor Mesny as intermediary, he made the acquaintance in Rome of a young physician named Giuseppe Iberti. Sade called on Iberti not only to guide him around the city but also to undertake for him the role of research assistant of sorts, locating scurrilous writings from Antiquity and other epochs in the Vatican Library. After Sade had left Rome, a letter from Sade to Iberti was intercepted and drew the scrutiny of the Holy Office. Iberti was arrested and incarcerated for almost four months, from September through December of 1776, in the Castel Sant'Angelo (the Mausoleum of Hadrian, converted into a papal fortress and subsequently prison). Sending the young doctor into the grasp of the Inquisition does not seem to have bothered Sade, and he continued to prod Iberti for information from afar, and this correspondence, also to be found in the final chapter of this volume, sketches this situation as well.

Sade visited the waterfalls at Tivoli and other sights proximate to Rome, but then shifted his attention further south. He arrived in the capital of the Kingdom of Naples in early January 1776. With the discoveries and initial excavations of Herculaneum and Pompeii in the mid-eighteenth century and reports of the majestic, hitherto neglected ruins of Paestum, Campania had become a must-see stop for travellers to Italy. ${ }^{29}$ The renewed activity of Vesuvius at around the same time further piqued the interest of amateur naturalists and anyone seeking to experience a purportedly sublime landscape. The region overflowed with sights. These included the supposed tomb of Publius Vergilius Maro (70-19 BCE), better known simply as Virgil in English and Virgile in French; ancient engineering marvels such as the Grotta di Posillipo; and the island of Capri, where the emperor Tiberius (42 BCE-37 CE) is said to have finished his days in splendidly heinous debauchery. These locales together with the realm's many other attractions would be thoroughly described and sumptuously illustrated in the four volumes of Voyage pittoresque; ou, Description des royaumes de Naples et de Sicile (Picturesque journey, or description of the Kingdoms of Naples and Sicily) by the painter and engraver Jean-Claude Richard, abbé de Saint-Non (1727-1791) and published in 1777-1778, shortly after Sade was back home in France. On this part of his Italian travels, Sade's companion and cicerone was Jean-Baptiste Antoine Tierce (1737-1794), Sade's senior by less than three years and a landscape painter of minor renown, academically trained in his native Rouen and subsequently Paris. Tierce had lived in Florence, currently resided in Naples, and was Doctor Mesny's son-in-law. He would provide a handful of illustrations for Saint-Non's opus, and also numerous sketches and illustrations for what was to have been Sade's published Italian project. Overwintering in Naples, Sade left that city in May, shipping two chests of antiques and natural curiosities ahead of him to France. With the clear intention of returning home, our marquis began to ascend the peninsula once more, taking in modern and ancient Capua, the Cascata delle Marmore, ancient artificial waterfalls near Terni, and the pilgrimage town of Loreto. Along this entire stretch, the manuscript is increasingly rough and fragmentary. Forging onwards to Rome, Bologna, and Turin, eventually arriving in Grenoble in late June, Sade sent word that he would soon be at La Coste, his chateau. ${ }^{30}$ He spent the autumn months more or less free and working on his project. Then in early 1777, Sade was lured to Paris to visit his dying mother. By the time he arrived there, on 8 February, she had already passed away. A few days later, Sade was apprehended by Inspector Marais and headed for Vincennes.

Both during his Italian journey itself and afterwards, while he continued to work on the manuscript and shape the project, Sade gained insights into his subject matter not only 
through personal contacts and correspondence, but also by consulting extensive printed materials. His main general guidebook was the work by abbé Jérôme Richard (1720?c. 1800) entitled Description historique et critique de l'Italie, ou Nouveaux Mémoires sur l'état actuel de son gouvernement, des sciences, des arts, du commerce, de la population, \& de l'histoire naturelle (Historical and critical description of Italy, or new memoirs on the current state of its government, sciences, arts, commerce, population, and natural history). Verbose book titles of this sort were common in the eighteenth century, and the current instance is relatively terse. Richard's six-volume opus originally appeared in 1766 and underwent numerous republications, including in 1769,1770 , and 1773 , not long before Sade's departure for his last trip to Italy. We know from page references given in the manuscript that Sade used the first edition, with a Paris and Dijon imprint. Very frequently Sade mentions Voyage d'un françois en Italie dans les années 1765 et 1766 (A Frenchman's journey in Italy in the years 1765 and 1766) by Joseph Jérôme Le François de Lalande (1732-1807), with page references confirming that Sade's was the eight-volume edition published in Yverdon in 1769-1770. Lalande's travel writing also extended to a voyage to England, although he made his name as an astronomer and authored several works in that field. Less often cited but mentioned and clearly employed was the 1764 publication entitled Nouveaux mémoires, ou Observations sur l'Italie et les italiens, par deux gentilshommes suédois (New memoirs, or observations on Italy and the Italians, by two Swedish gentlemen) by Pierre-Jean Grosley (1718-1785). As that title implies, Grosley initially passed off this work as the collaboration of Scandinavian compatriots and translated from Swedish. It was no such thing, as later editions openly attest. Subsequently, in 1774, Grosley published the work under his own name as Observations sur l'Italie et sur les Italiens, données en 1764, sous le nom de deux Gentilshommes Suédois (Observations on Italy and on the Italians, given in 1764 under the name of two Swedish gentlemen). Perhaps he dropped the ruse in order to claim success, for in the last quarter of the eighteenth century Grosley's guidebook, along with Lalande's, would be well thumbed by both French grand tourists and those enjoying a virtual voyage at home. Finally, Sade frequently refers to Voyage d'Italie (Journey to Italy) by François Maximilien Misson (1650?-1722), which had first appeared in 1691, was regularly reissued, and dominated the French market for guidebooks to Italy for the better half of the eighteenth century. We know from page numbers that Sade's edition was from 1743 with an Amsterdam imprint.

These four were not the only general guidebooks available to Sade, but they do appear to be the primary ones that he consulted, along with apropos sections of Voyage en France, en Italie et aux îles de l'Archipel, ou lettres écrites de plusieurs endroits de l'Europe et du Levant en 1750, avec des observations de l'auteur sur les diverses productions de la nature et de l'art (Journey to France, to Italy, and to the islands of the Archipelago, or letters written from several places in Europe and the Levant in 1750, with observations by the author on various natural and artistic productions). ${ }^{31}$ This work was first published anonymously and in English. Traditionally, it has been attributed to a Dr Maihows, but it enjoyed considerably more success in Philippe-Florent de Puisieux's expanded French translation, published in Paris in 1766, than in the English original. ${ }^{32}$

Sade also took advantage of city and regional guidebooks. In Rome, Sade appears to have used the guide to the Capitoline Hill and ancient Forum attributed to Giampietro Locatelli (also found as Giovanni Pietro Lucatelli; dates uncertain) and initially published in 1750 as Museo Capitolino o sia Descrizione delle statue, busti, bassirilievi, urne sepolcrali, iscrizioni, ed altri ammirabili, ed erudite Antichità (The Capitoline Museum, or 
description of the statues, busts, bas-reliefs, urns, tombs, inscriptions, and other remarkable and erudite antiquities). Another important source for Sade was a three-volume guide to the ancient points of interest in the vicinity of Rome, and particularly the Tivoli area, by Bertrand Capmartin de Chaupy (1720-1798), entitled Découverte de la maison de campagne d'Horace (Discovery of Horace's country house) (1767-1769). Chaupy was an ordained priest who, having been proscribed in France for his polemical writings, took up residence in Rome and there fashioned himself into an expert antiquarian. His aforementioned work documented the rediscovery of Horace's Sabine villa near modern Licenza, as well as many other ancient sites in the Roman countryside. Not everyone agreed with Chaupy's assessments. The celebrated engraver of Roman vedute and fantastic capricci, Giovanni Battista (or Giambattista) Piranesi (1720-1778), for instance, made a satirical print against Chaupy that portrayed the site of the supposed villa on the cover of the Frenchman's work in the unmistakable shape of excrement. ${ }^{33}$ In the vicinity of Naples, Sade consulted Guida de'forestieri curiosi di vedere, e di riconoscere le cose più memorabili di Pozzoli, Baja, Cuma, Miseno, Gaeta (Guide for foreigners curious to see and identify the most memorable things in Pozzuoli, Baiae, Cumae, Miseno, Gaeta) by the clergyman Pompeo Sarnelli (1649-1724). It was first published in Naples in 1685 but subsequently translated into French and augmented by Antoine Bulifon. For Naples proper, Sade used Sarnelli's complementary 1688 guidebook, Guida de'forestieri, curiosi di vedere, e d'intendere le cose più notabili della regal città di Napoli (Guide for foreigners curious to see and to understand the most noteworthy things in the royal city of Naples), also translated by Bulifon. These late seventeenth-century works were still in print and much used at the time of Sade's visit to these areas. They existed in bilingual editions, with French and Italian on facing pages. This was presumably helpful for the French traveller without sufficient Italian, and we know from his correspondence that Sade himself was learning the language but frustrated with his fluency, or lack thereof. In a letter to his solicitor of 10 August 1775, our marquis writes: "It's devilishly hard to make yourself understood here; not a soul speaks French, and I am quite far from speaking Italian yet. Nonetheless, I'm working like a demon on it." ${ }^{34}$ An acquaintance tells him that he'll never attain his goal without taking an Italian mistress. Sade asserts that this is "a means that I will certainly never use." ${ }^{35} \mathrm{He}$ apparently changed his mind shortly afterwards.

Guidebooks were not only something Sade used: the aim of his project was also to provide one. This meant carving out a space in an already crowded market and distinguishing his contribution from those of his rivals. Judging from how often he mentions its deficiencies, Sade saw abbé Richard's recently published Description historique et critique as his chief competition. Richard, for his part, claimed that what was shockingly lacking and what he hoped to be offering was "a description methodical enough and extensive enough to be of real utility to the traveller," along with an "accurate idea" of Italy for those unable to make the trip. Richard condemns his predecessors in the Italy guide publishing business for their trite generalities, dressed up and presented as novelties and further tricked out with "satirical jests" and "obscure anecdotes" gleaned from cafés. ${ }^{36}$ Criticizing what he sees as the common problem of superficial and inaccurate writers on Italy, Richard does not exclude Misson, whose "work has endured for seventy years and is regarded as the most curious and most exact account of Italy that has been made." ${ }^{37}$ According to Richard, Misson seems merely to have passed through and that explains why he somehow believed it possible for a traveller to spend only five days in Naples, three in Florence, and even less time in Bologna. Sade will have similar remarks to make about his fellow travel writers 


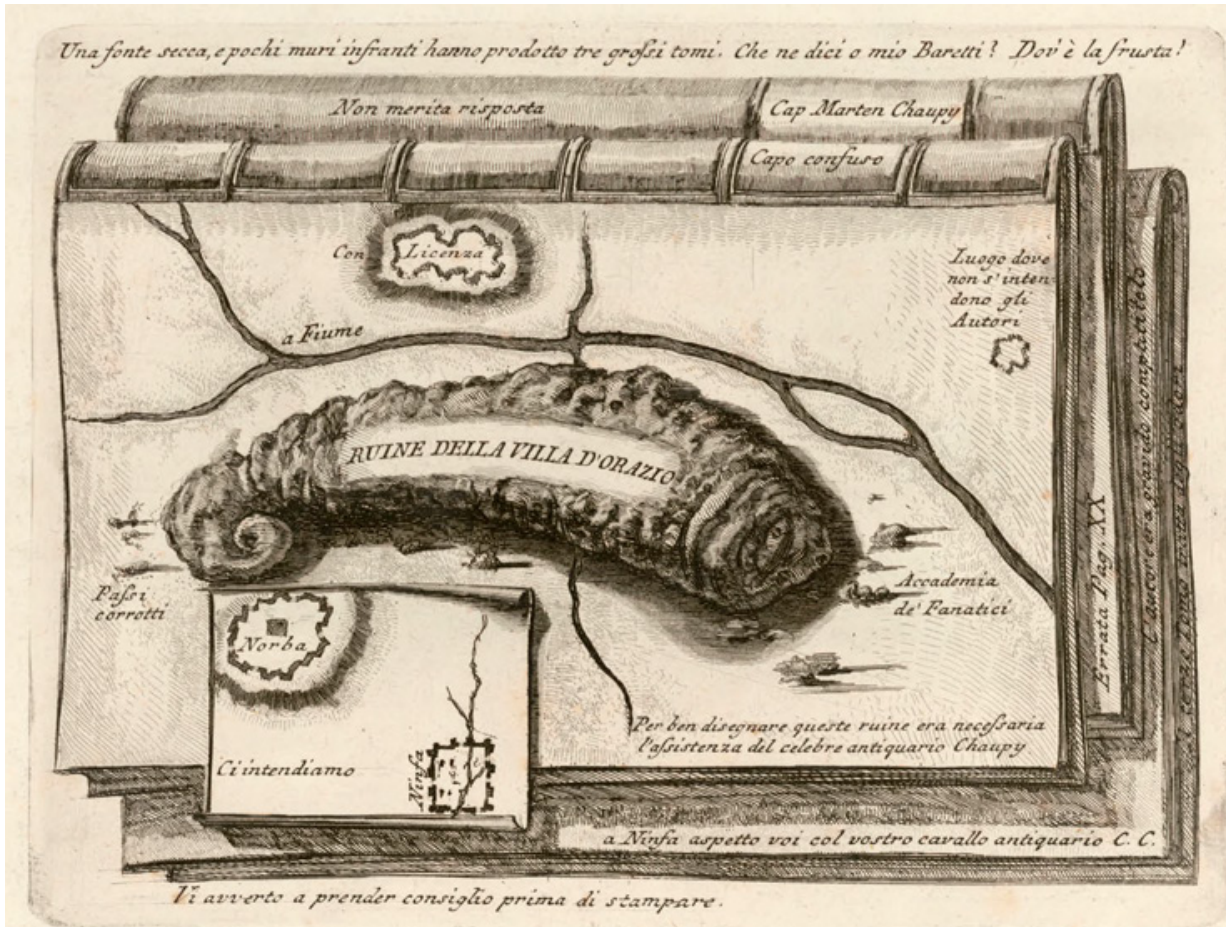

Figure 0.1. Satirical print on Chaupy's Découverte de la maison de campagne d'Horace, from Giovanni Battista Piranesi, Diverse maniere d'adornare i cammini ... (1769).

and will insist on the depth and duration of his own explorations at his principal stops in Florence, Rome, and Naples. Such depth was also meant to excuse the partialness of Sade's account, for he certainly could not claim to have seen all of Italy during his tour, and Venice, in particular, is glaringly missing from the work. Throughout his manuscript, Sade attacks his competitor on precisely the objectives Richard had claimed to fulfil: disputing the utility as well as the accuracy of the guide and complaining vociferously, sarcastically, and in the end, monotonously about the abbé's errors, omissions, and lapses in judgment. We could certainly read Sade's numerous asides as evidence of our author's tetchy disposition, but it is also fair to say that travel guides, now as then, could deserve criticism and their flaws could very well be a source of understandable irritation. Less obviously, guidebooks also reveal partisan stakes and can have a polemical flavour. Richard, a Jesuit, disapproves of Misson's tendency to "ridicule at times the Catholic religion, and almost always at the expense of the truth. ${ }^{38}$ Himself a Huguenot, Misson had no admiration for the Church of Rome. Sade occasionally jests about Richard's presumed biases, and the abbé's affiliation helps explain our author's animus. Moreover, Sade likely appreciated Misson's often satirical stance on the Church and sought to sharpen such criticisms. Indeed, what Sade ultimately hoped to provide was a philosophical vade mecum that would penetrate deeply and critically into its subject matter. His project would be a guide to Italy, but especially one worthy of the Marquis de Sade's budding ambition to join the ranks of the lettered and enlightened. 


\section{The Philosophical Informant}

On top of the triumphal column of Trajan (53-117 CE) in Rome there originally stood a statue of the emperor. This disappeared at some point after the fall of the Western Empire. In the sixteenth century, at the behest of Pope Sixtus V (1521-1590) the missing statue was replaced with one of Saint Peter. Concerning the substitution, Sade wonders "if he [Trajan] were to return to Rome, with what astonishment would he see on the monument erected to his glory the statue of a charlatan who was ten-a-penny during the reign of his predecessors?" Probing further, he asks, "With what eye does the philosopher descry this profanation, and how might he see Nero's buffoon occupy, by the most bizarre blindness, the place intended to honour and to perpetuate for all time the memory of the world's emperor, who at the time this monument to his glory was being set up, was losing his life in a war essential to the empire?" Of course, these are less hypothetical than rhetorical questions. Sade obviously identifies himself with such a philosopher and assumes that his reader will likewise take up a viewpoint that discerns in the rock upon which the Church was built a clownish huckster and in a pagan ruler an exemplar of national service and virtue. This position was important to Sade, who considered at one point titling his Italian project "The Philosophical Informant." Sade may have intended the term "philosopher" to entail broadly a critical mindset, yet by the time of his writing, philosophe in French also had a narrower, partisan sense: a philosophe, by then, was considered to be a member of the intellectual, social, and in many respects, political movement that upheld reason as the means to progress and that was highly critical of institutional religion and all that it deemed superstition..$^{39}$ The movement was multifaceted and certainly had its detractors, expressed, for example, in the anti-philosophical stance of the Jesuit-dominated Journal de Trévoux. For their part, philosophes generally reviled the Jesuits above all - their dangerously intellectual peers - and for his part, Sade, schooled at Paris's then Jesuit-run Collège Louis-leGrand, had developed a typical philosophical distaste for his former teachers.

For some time now, intellectual historians have been wary of placing the European eighteenth century under the rubric of the Enlightenment. The term itself was retroactively applied, and it captures neither the social and cultural complexities and contentions of the era nor the variety of local and regional instantiations of philosophical engagement. But while there never was such a monolith, there certainly was a social network of like-minded thinkers, communicating face to face, via correspondence, and through the medium of print. Among the roots of this movement was the early modern revival of scepticism. A key moment and a work that still informed Sade's manuscript some three-quarters of a century later was the Dictionnaire historique et critique (Critical and historical dictionary) by Pierre Bayle (1647-1706) and initially published in 1697. An exiled Huguenot, Bayle undertook arguments to undercut institutional Christianity and to emphasize the necessity of faith and the value of tolerance. ${ }^{40}$ Among eighteenth-century philosophes, such thinking was easily adapted to attacking the Catholic Church and for a general assault on credulity. From an emphasis on the irrationality of faith came rationalist defences of deism and atheism. To the sceptical position was added a good dose of cynicism: priests were not themselves deluded but, rather, hypocritical beneficiaries of lies baldly proffered to benighted believers.

The most renowned of such "philosophers" was certainly François-Marie Arouet (16941778), known by the nom de plume Voltaire, whose acid wit was often combined with a taste for ribaldry. Sade cites Voltaire occasionally in the manuscript of Journey to Italy, 
including the scurrilous satirical poem on Joan of Arc and fanaticism, La Pucelle d'Orléans (The Maid of Orleans), and he clearly knew Voltaire's vast oeuvre well. More broadly, Sade frequently speaks of religious "chimeras [chimères]" - a common philosophical term for the work of misguided imagination - and points out that a "philosophical spirit [esprit philosophique]" is not easily misled. He criticizes or simply insults key historical figures in the development of Christianity, including Jesus, "the new magician of the Jews." $\mathrm{He}$ expends both more ink and more ire on Saint Peter, "today so celebrated and so sanctified in Rome," but originally "a poor fisherman" and "one of the first idlers that the opportunist Jesus" fashioned into a follower. After the death of his leader, Peter continues the tradition of performing dubious miracles witnessed by few. He is said to have travelled to Rome, where in Nero's palace he has an "odd combat" with Simon Magus. Here was one fraud fighting against another. Sade finds no credible evidence that Peter made it to Rome at all, "satisfied with catechizing in Judea" or "perhaps in some other unknown corner of Asia." Anyone who affirms that Peter was bishop of Rome is plain wrong, and later popes who claimed him as "the first pontiff and the first head of the Church" merely took advantage of a "fortunate pun" in which Peter became the foundational rock. His real name was Simon anyway.

As for the rank and file of early Christians, Sade mentions the satirist and historian Lucian of Samosata (c. 125-after 180), who describes them as "an assembly of ragged tramps with feral miens, maniacal comportment, sighing, contorting themselves, swearing by the son who had come from the father, predicting a thousand misfortunes for the empire, blaspheming against the emperor and against anyone who did not think like they." 41

To Sade's philosophical eye, little had changed.

Sade did not consider Christianity an entirely foreign imposition on Rome but rather an exacerbation of indigenous tendencies and all-too-human susceptibilities. Romulus thus exploited religious gullibility to found Rome and become its first king. For this argument, Sade drew from Histoire des révolutions arrivées dans le gouvernment de la République romaine (History of the upheavals undergone by the government of the Roman republic), which discusses the growth of superstition in early Rome and, first published in 1719, was by the clergyman and historian René Aubert de Vertot (1655-1735). Writing of Numa Pompilius (traditionally 753-673 BCE), Rome's legendary second king, Vertot argues that the ruler instilled fear of the gods and used augurs and haruspices for political ends: "The veneration for these superior Beings, all the more redoubtable to the extent that they were unknown, was a consequence of these prejudices. Rome insensibly filled with superstitions; politics adopted them and put them to pragmatic use to keep a still ferocious people in submission." 42 Vertot was a Premonstratensian and a priest. It made sense that he would treat pagans as prone to false worship. Sade's philosophical gambit was to blur these lines. He posited that the Church and Christianity as they developed in Europe, and above all in Italy, was an amalgam of endogenous pagan beliefs and exotic oriental credulity. There from the outset, at least for a while, these servile roots competed with more admirable republican values and muscular virtues. Sade reserves particular disdain for the emperor Constantine (c. 272-337), who replaying the "first imposture" to historically disastrous effect, "betrayed his conscience for the sake of politics." We have Constantine to thank for the "current status" of the "Christian error." In his mould, modern popes are nothing but corrupt emperors of the Papal States and of greater Christendom. Although Sade will express occasional appreciation for popes as patrons of the arts, on the whole, he offers few good words about the office or its holders. The papal delusion is summed up in Sixtus V's 
farcical substitution on Trajan's column. Sade would also note the pagan roots of modern Christian customs such as the Jubilee years that popes occasionally declare. These become an occasion for "debauchery and libertinism," since all is forgiven in advance and criminal justice is put on hiatus, with even executions suspended for the duration of the celebration. Still, Sade the hedonist must admit that such pontifically sanctioned "moderation" - euphemistic for licence - is "in truth quite praiseworthy."

The critique of institutional religion in the eighteenth century was a widespread philosophical trend with various degrees and varying rhetorical modes. When Sade uses logic and empirical inference to debunk the authenticity and efficacy of relics and other holy artefacts, "these rattles of the infancy of Christianity," his underlying position is similar to that of Immanuel Kant, who argues in his 1784 essay "Was ist Aufklärung?" ("What is enlightenment?") that the term signified humanity's steady emergence from its childhood as a species. ${ }^{43}$ If we still require political direction from above, we are also moving towards maturity and self-governance. Granted, Sade's observations tend to be delivered with a Voltairean lip-curl aimed at a populace in need of such mental crutches and at those happy to profit from ongoing infantilism. Sade appears to have considered religious imbecility a constitutive tendency of the Italian nation, its past and present awash in examples. Rome and its territories may be the historical and actual centre of organized religious corruption and fanaticism, but other Italian states, cities, and towns were hardly immune. Florence saw the rise of the monk Girolamo Savonarola (1452-1498), a "dangerous frenetic," who "in league with the king of France" led a populist takeover of the city in the late fifteenth century. In contemporary Loreto, the credulous come to marvel at the Santa Casa, the supposed house of the Virgin Mary, transported or angelically translated - to employ the usual term for this feat - from Jerusalem. Naples provides several prime examples of ensanguined fanaticism, savage intolerance, and cynical exploitation. There are the demagogic street preachers inciting violence, as well as processions of flagellants. (Granted that Sade holds the practice of religious flagellation in disdain in the Italian manuscript, this is not without irony given his sexual proclivities and practices.) The celebration of Maundy (Holy) Thursday in the city presents the outside observer with a spectacle that combines ostentation, particularly inappropriate at what should be a time of mortification, with gruesomeness. Aristocrats outfitted in black velvet, covered with diamonds, process in gilded sedan chairs. Finely liveried footmen accompany their bedizened masters to various churches. In one chapel, the entourage visits a mocked-up sepulchre in which there is a facsimile of Christ's corpse - termed by Sade "the horrific idol" - shrouded in the incense of superstition. The following day, various aspects of the Passion, modelled with "frightening realism," are paraded through town on litters. For Sade, this bloody display of devotion is revolting. It makes "one despair that the torch of philosophy should ever pierce into a country wherein the thickness of the darkness of superstition still subjugates minds to such a degree." Sade also considers at length what happens when the vial containing the dried blood of Saint Januarius in Naples is set to miraculously liquefy. Credulity is manipulated and mingles with mob mentality: the people demand a show and turn murderously on suspected non-believers.

How extreme was Sade's stance on religion at the time of his Italian sojourn? Atheism, cryptically expressed, was an increasingly common position in mid-century philosophy, and one that developed in tandem with neo-Epicurean materialism, which sought to derive order and sensibility from atomic interactions and that considered death to be the mere dissolution of atomic bonds. Such materialism will be found in works such as L'homme 
machine (Man, a machine) by Julien Offray de La Mettrie (1709-1751), published in 1747, as well as Le Rêve de D'Alembert (D'Alembert's Dream) by Denis Diderot (1713-1784), written in 1769 but published posthumously. There were also strong links between these atheist tendencies, materialism, and the philosophically inclined licentious fiction that had developed in the 1740s. This conjunction was advertised in the very title of one of its most important instances: Thérèse philosophe (Theresa, the philosopher) by Jean-Baptiste Boyer, Marquis d'Argens (1703-1771), published in $1748 .{ }^{44}$ Boyer d'Argens was a prolific writer in a variety of genres, including philosophical criticism of institutional religion, and his works enjoyed a prime spot on Sade's bookshelf. His Lettres juives, ou Correspondance philosophique, historique, et critique (Jewish letters, or philosophical, historical, and critical correspondence) (1736-1739), for example, was Sade's main source of information on Jubilees and their consequences. ${ }^{45}$ In the second half of the eighteenth century, expressions of atheism became more common and strident. Deism now appeared tepid and noncommittal, at least to some within the radical wing of philosophie. The writings of Paul-Henri Thiry, Baron d'Holbach (1723-1789) vociferously combined Voltaire's bent for exposés of priestcraft with an unequivocal embrace of non-belief. D'Holbach, who was from the Rhenish Palatinate, went to Paris where he ran a salon. The most famous, or infamous of his writings was his Système de la nature (Nature's system) (1770), which appeared as Sade was coming of philosophical and libertine age. Of course, all such works were anonymously and clandestinely published. Sade does not cite d'Holbach explicitly in the body of his manuscript, nor would we expect him to do so. D'Holbach's writings are indicated in the dossiers, however, including his Théologie portative ou Dictionnaire abrégé de la religion chrétienne. Par M. L'Abbé Bernier (Portable theology, or abridged dictionary of the Christian religion. By M. l'abbé Bernier) (1768), a mock dictionary highlighting the negative aspects of ecclesiastical history. Sade did have other sources in the virulent antiChristianity camp, including L'Antipapisme relevé, ou les Rêves de l'antipapiste (Antipapism revealed, or dreams of the anti-papist) by Henri-Joseph Dulaurens (1719-1793 or 1797), a defrocked monk, satirical poet, and novelist. Among other things, this work, published in 1767, detailed the sodomitical exploits of popes such as Julius III (1487-1555). Sade does not present extended accounts of his views on religion in the drafted chapters of Journey to Italy, but does offer numerous sly and often cutting asides that reveal a radical philosophical viewpoint and confirm that the professed atheism of his later writings was already firmly in place. As he comments in a long note on the geology of granite (of all things): "Each century has brought, so to speak, a different cult. Atheism alone has never varied, and in whatever guise one has deemed fit to depict the gods, there have ever been found philosophers wise enough to feel that Nature has no need of a master and that the one that superstition lends her is only a monster of the imagination."

\section{Politics and Policing}

The critique of religion was only one facet, albeit a salient one, of the philosophical program, which also aimed at more direct engagement with governance. Sade tends to evince cynicism with regard to political power, but also a simultaneous investment in what would come to be called "enlightened despotism": the notion that an informed and reasonable ruler is the best hope for well-governed, prosperous state. Voltaire famously joined the court of Frederick II, the Great of Prussia (1712-1786) at the monarch's bidding and for the purpose of providing sage counsel. Frederick himself was a committed philosophe 
and published, for instance, on the reform of the German language, how to rationalize its grammar and render its expression clearer. The two men ultimately fell out, and Voltaire would lampoon Frederick, comically insinuating the ruler's homosexuality, in Candide, ou l'Optimisme (1759). At her behest, Diderot spent several months in 1773-1774 at the court of Catherine II, the Great of Russia (1729-1796), who was not without libertine inclinations, and in philosophical conversation with the monarch. Sade was not an established thinker or writer, and his encounters with Italian potentates were cursory or at a remove. He nonetheless celebrated enlightened rule and disparaged shortcomings on this front. He sings the praises of Joseph II, Holy Roman Emperor from 1765 to 1790, who had attempted to reform the Church of Rome by annexing various prerogatives of the pope and other bishops. ${ }^{46}$ Sade points out that when Joseph visited the Vatican, the emperor sat on the cathedra, put his hat on his head, and said, "I feel quite comfortable here." Sade takes the purported occurrence as a sign that the papacy itself might be at an end, and he is clearly pleased with that notion. Sade has measured praise for Peter Leopold, Grand Duke of Tuscany (1747-1792) at the time of Sade's Florentine stay. Leopold had abolished the death penalty, and Sade was a consistent opponent of capital punishment. Given the sentence in Marseilles, his view suggests self-interest, but he was also implicitly following the enlightened position of the Milanese philosopher and jurist Cesare Beccaria (1738-1794), whose profoundly influential Dei delitte e delle pene (1764) (On Crimes and Punishments) he owned in French translation, with commentary by Voltaire. ${ }^{47}$ Sade describes Leopold as a ruler "as philosophical as he is gentle and humane," who understands "the price of a man's life," and who has grasped that the crime itself is "not destroyed along with the wretch who committed it." 48 Conversely, Sade wishes that Ferdinand IV (1751-1825), the young monarch of the Kingdom of Naples, were of a more philosophical inclination, both for the sake of his people and for posterity.

Treating enlightened rule or the apparent lack thereof was only a fraction of what a politically astute philosophical informant needed to cover. Consider how Sade's perceived chief competitor understood his remit in this regard. In the foreword to his account of Italy, abbé Richard complains that Misson not only had insufficient knowledge of the arts but also failed to discuss many worthwhile topics such as government, population, commerce, different manufactures, and various other facets of Italian society. In short, Jérôme Richard holds that a guidebook equal to its task ought to encompass politics in a manner extending well beyond the top of the hierarchy of a nation. From a historical perspective, Misson's failure is understandable: he was writing prior to the burgeoning interest in these topics and, in particular, before the watershed marked by that most famous work by the philosophe we know as Montesquieu (1689-1755): De l'esprit des lois (1748) (Spirit of the Laws). Montesquieu's was a magisterial assessment of the relations between governance, legislation, customs, and national "genius," that is, the particularity and mindset of a given group of people, both in the past and in the present. In the second half of the eighteenth century, such proto-sociological assessments became increasingly available. We know from the various titles for his project with which Sade toyed in Geneva on 15 August 1776 - fresh from completing his journey to Italy and on his way home - that he believed his task included an endeavour "to note with care the roles of legislation, government, forces, population, and mores always neglected up to the present." The last term was crucial: mores or mœeurs, in philosophical parlance, largely denuded of moral and religious overtones, fell betwixt and between customs and culture in the later anthropological sense. They were akin to what Pierre Bourdieu (1930-2002), drawing on an ancient Greek term for engrained second 
nature, would famously call habitus: historically, institutionally, and culturally shaped dispositions that act as "a system of cognitive and motivating structures." 49 Abbé Richard had put the matter like this: "To provide a general idea of the mores of a nation means to expose the fundamental principles that order them and the effects that result therefrom in the ordinary conduct of life. $" 50$ There is no reason to think that Sade would have disagreed with this assessment.

To be sure, not all factors shaping the genius of a nation were conventional. In particular, the notion that climate (French, climat) had a decisive effect on human behaviour and biology held sway throughout the eighteenth century. Including average temperatures and seasonal variations in a given place, in Sade's day climate was capaciously conceived, shading off into what we might call more generally the natural environment. Climat was used to explain racial variety, which entailed differences in mores and not simply skin colour and other superficial features, as well as national tendencies. ${ }^{51}$ The overall Italian reputation was one of indolence, deteriorating the further south one travelled. Confirming the stereotype, abbé Richard observes that in terms of commerce and manufacture, Italians are not as lazy as generally supposed. What languidness exists is largely a factor of natural abundance in a temperate clime. Added to this, charitable institutions inadvertently encourage softness and idleness. Richard tells his readers that the Italian "habit" is not to stockpile or otherwise save but to "live from day to day." 52 This behaviour tempers profit seeking and the hot pursuit of wealth witnessed among traders and labourers elsewhere in Europe. The mindset results in misery when a harvest fails and charities are overwhelmed, as with the famine that struck Naples in 1764. Sade makes similar observations, especially regarding this southern city and its vicinity, where natural bounty produces fallow subjects.

As mentioned, Richard is critical of Misson's lack of attention to mores and related matters, yet he simultaneously excuses himself from precisely the tasks of discovering and examining in detail the fundamental principles that underlie national habits and the particularity of a nation's genius. He judges these tasks to be beyond his scope and powers. Richard's superficial humility is driven by the explicit distinction he makes between his approach and that of philosophie. He refuses to indulge in those "bold and wicked reflections that spare nothing to cast as ridiculous that which the Catholic religion has in its practices and ceremonies worthy of respect." ${ }^{53}$ Richard considers the morale dominante or the fundamental mindset in Italy to be sacred show: "All that is exterior in religion." 54 He identifies disadvantages to this approach such as a failure to attend to inner reform, but points out that the "peculiarities" this mindset produces are balanced by benefits: the show is sufficiently magnificent to "raise the soul up to its august Creator." 55 Further, while Richard is clear-eyed when it comes to intrigue, backbiting, and political machinations in the Papal States, he does not try to unearth some deeper structure at work. Sade, however, taking up the mantle of philosophe, aimed to illuminate the tangled skein of attitudes, comportment, laws, habits, history, and climate in Italy, and there is evidence of these efforts throughout his manuscript, albeit more in the way of sketches and intermittent attempts than the comprehensive accounting that he sometimes seems to have envisioned. Italian attitudes towards and expressions of religion are certainly part of this endeavour, although many other topics are entwined with the imperative to understand mores. There is, for example, Sade's examination of cicisbeismo in Florence. This was the convention, common among not only Florentine nobles but also in some other Italian cities as well, by which married women were served and publicly escorted by a male companion or cicisbeo. Our marquis, understandably, sees this institution as a sort of socially sanctioned adultery, 
and while he thought the arrangement worthy of derision, he also tried to grasp its roots and effects. The same imperative is behind his interest in the spectacle of the cuccagna or cockaigne floats in Naples, where the lower orders violently vie for viands presented by the ruler. That Sade could also use his witnessing of such an event to condescend while lingering over a lurid bit of exotica goes without saying - and there was nothing unusual about that in travel writing.

Increasingly, mores were considered not simply something to be observed and explained: they required intervention and were deemed a matter for la police or "policing." 56 The term, derived from the Greek polis or city, was initially restricted in reference to urban management. Policing not only included the prevention, containment, and prosecution of criminal activity, legislation, and enforcement but also numerous other concerns such as food supply, sanitation, hygiene, and traffic. The apparatus as such was fairly novel in Sade's day, emerging in tandem with the absolutist reign of the Sun King, Louis XIV (1638-1715), although the governance and regulation of cities had obviously existed previously in other guises. Paris's first lieutenant general of the police, serving from 1667 to 1697, was Nicolas de la Reynie. He urged Nicolas de La Mare, the superintendent at the Châtelet court and prison complex in Paris, to undertake a thorough study of the subject, and in 1707, after years of archival research and first-hand experience, de La Mare brought forth the first volume of his Traité de la Police (Treatise on policing) on the history, branches, and proper functioning of urban management. By the middle of the eighteenth century, policing had become entwined with another concept of recent provenance, and that is population, not simply as the number of subjects in a given territory, but as the source of a state's wealth and power, something to be grown and shaped. Certainly, there were earlier discussions of population, but the crucial work in the eighteenth-century French conversation was L'Ami des hommes, ou Traité de la population (The friend of mankind, or treatise on population) by Victor de Riqueti (often given as Riquetti), Marquis de Mirabeau (1715-1789) and published in 1756. This work was associated with the economic theories of the physiocrats, led by François Quesnay (1694-1774) and Anne-Robert-Jacques Turgot (1721-1789), which held that agrarian workers produce the nation's true riches, whereas merchants produce nothing of tangible value. Policing and population as concerns were not confined to partisan philosophie - on the contrary, there was an often tense relationship between philosophes and physiocrats; they were, however, matters of general intellectual interest, and a philosophical informant such as Sade would certainly need to have a view on them.

At various moments in his manuscript of Journey to Italy, Sade addresses two significant issues related to population and policing broadly speaking: religious sequestration and prostitution. Once again, our author's interests here were not original; rather, he provides insight into some of the most debated matters within and without philosophie. Montesquieu, for example, in his satirical epistolary novel Lettres persanes (1721) (Persian Letters), employed the Oriental harem with its sequestration of women and its eunuch guardians to criticize the Catholic institution of monasteries and convents, their deleterious effects on population, and their distortion of presumed natural sexual relations. ${ }^{57}$ Sade follows similar lines in his Italian project. Convents take women out of sexual circulation and are noxious to population as the wealth of nations. Condemning the ancient Roman enforcement of capital punishment for Vestals who violated their oath of virginity - "it is odious to punish with death those whose entire crime is to have laboured to give life" - Sade finds in convents "a reflection of this ancient barbarity." Convents are simply the modern way that humans, "ever blind and superstitious," sacrifice to a "false divinity," and thereby harm 
individual humans as well as the interests of humanity and the state. Monastic orders are similarly damaging, and their proliferation in Italy reveals that "the rage to extinguish the human species" is ubiquitous there. Touching more on the matter of political management, Sade argues that monastics are not only biologically but also economically unproductive, all the while enjoying immense wealth. This he traces to the long history of Italy: When the Roman Empire succumbed to barbarian invasions and suffered devastation, monks were "granted large territories to cultivate." This was done out of a "philosophical" principle: idlers were rightly put to work. But, Sade continues, as soon as the lands were fertile and productive, the state ought to have reclaimed them. Instead, the monks were allowed to accumulate wealth and to revert to idleness. With wealth and idleness come debauchery, and so today it is "not rare to see those of them in Italy who maintain, in the heart of their convents" - the term couvent was not gender-specific in eighteenth-century French, just as "convent" was not in English at the time - "a sufficient number of young girls to satisfy their carnal appetites." These "creatures" are "forever removed from society" and are buried along with "the productive faculty that they have received from nature." According to Sade, religious sequestration diminishes the population and its productive capacity by at least a third. A tour through Italy is striking for the depopulation of the nation's towns and cities, above all in the Papal States, "where priesthood and monasticism are the most esteemed and the most in force."

Prostitution, while seemingly at the other end of the spectrum from religious celibacy, ultimately raised similar concerns about population. From the point of view of policing, libertinism was less an immoral or amoral philosophy of pleasure and an accompanying literature than a social ill, and whether as cause or effect, prostitution was its problematically obvious manifestation. Indeed, one danger of sex work in cities was the very publicness of the trade and the corrosive effects of immoral and unhealthy behaviour on display. French policing had been dealing with this problem for a long time and with limited success. De La Mare in his Traité de la Police records that, in France, "public" places of sexual commerce were forced out by law in the sixteenth century, a policy still in force when he was writing. What happened next is that private houses were rented out and certain areas became associated with the sex trade (Faubourg Saint-Germain in Paris is noted as particularly atrocious). The levying of fines and confiscation of rents works to an extent, as does imprisonment of the women in egregious cases. Still, there is no way to stamp out the practice, especially in large cities, no matter the severity of laws, regulations, and punishments: "the petulance of an incorrigible and corrupted youth" in cities triumphs frequently over careful "domestic education by fathers and mothers and over the vigilance of public magistrates and officers." ${ }^{58}$ In 1656, de La Mare reports, maisons de force or correctional prisons were established to impose control over young offenders, with men under the age of twentyfive being sent to Bicêtre and women to La Salpêtrière for punishment and disciplining. Needless to say, prostitution did not end there, and publicness remained an issue of grave concern. Sade himself remarks with dismay that, in French cities, "the wretched victims of debauchery" wander "insolently in the evening hours" and openly solicit "passers-by to enjoy their odious favours." By the middle of the eighteenth century, however, the policing apparatus had also become deeply engaged in the surveillance of aristocrats and in controlling not only what happened publicly, but also behind the doors of brothels - known as maisons closes or "closed houses" - and petites maisons. To take a pointed example: on 7 December 1764, vice Inspector Marais reported to Antoine de Sartine about Sade's latest doings. A year had passed since Jeanne Testard had disclosed to the lieutenant general of 
the police the marquis's sacrilegious antics, which had led to his short stay in the Château de Vincennes prison. Marais notes that Sade, having been released and accompanied to Provence, had obtained permission to return to Paris in the summer, and there he remained. What was he up to? Marais reports that he has "amused himself by giving 25 louis per month to a young lady named Colette, an actress at the Italian [i.e., Comic Opera], who lives with Monsieur the Marquis of Lignerais, who is accommodating enough to play second fiddle when a good opportunity presents itself to her." ${ }^{59}$ Marais continues that Sade, for his part, has begun to realize that he is this "young lady's dupe" and that "this week he went to vent his spleen at the house of Brissault, whom he insistently asked whether she knew me." ${ }^{90}$ Madame Brissault was one of the most reputable procuresses in Paris. Nicknamed La Présidente, at the time she ceded only to Marguerite Gourdan in brothel-keeping renown. ${ }^{61}$ Brissault assured Sade that she did not know Marais; clearly, the opposite was true. Marais, without going into details, sagely advised her not to "furnish him with a girl to take to a petite maison." 62

Given Sade's biography, we might imagine that his views on the policing of prostitution would be complicated. Propensities and practices aside, libertinism was not something he would have advertised in print. Given his philosophical intent in Journey to Italy, his observations on prostitution and policing position him as someone striving to be reasonable and ethical about sex work. For instance, he calls the sequestration of prostitutes to a specific quarter "perhaps one of the best regulated parts of policing" in Florence, conducive to public order and peace, as opposed to the case in France. In Rome, however, he is shocked by the openness of clerical licence, where cardinals "publicly" provide examples. Naples is the nadir. Sade finds that it is "physically impossible to imagine" how engrained the problem is there and that the city appears to be beyond redemption. What to do about "a land where the climate, the food, and the general corruption constantly encourage debauchery"? When the sun sets, the streets teem with "unfortunate victims offered up to the brutal embraces of the first comer." The pleasures available are cheap and varied. Sade adds with a perhaps disingenuous shudder that many of the women soliciting in Naples are not women yet at all: "little girls of four or five offering themselves up for the most horrific debaucheries" and who "provoke you for the vilest sum to indulge in every type of libertinism that imagination can conceive." The young girls whom Sade witnessed propositioning in Naples not only intimated that anal sex was an option but even begged, "when someone had succumbed to their solicitations, to choose that manner rather than the one Nature prescribes, because the frailty of their age meant that they were not capable of participating in the usual practice to which the Creator has destined their sex." Boys propose themselves in the same fashion. Indeed, prostitution in Naples is a veritable family affair: mothers offer you their daughters and sons; sisters pimp their brothers, fathers their daughters, and husbands their wives - and all for lucre. Sade wonders, "What becomes of virtue, population, health in a State where the degradation of mores has come to such a point and where the scrappiest temptation of profit suffices to lead to crime and to reverse the very notion of probity, honour, and virtue?"

Such "libertinism," which presses in from every side in Naples, has the unfortunate effect of crowding out "that delicacy, that delicious sentiment born of the union of two hearts born to love and to respect one another and that alone polishes mores and softens them." If it is a bit surprising to see a dedicated libertine in lifestyle conclude that love is the key to civilized mores, Sade had company. In 1769, Nicolas-Edme Rétif (or Restif), also known as Rétif de la Bretonne (1734-1806), low-rent libertine and copious hack, had published an 
epistolary novel-cum-treatise on the policing of the sex trade called Le Pornographe (The pornographer). ${ }^{63}$ The title signifies etymologically someone who writes about prostitution, and the work argues that the legalization, sequestration, and hygienic surveillance of the trade would remove it from the public eye, serve as a source of revenue for the state, help maintain a healthy population, and lead to happier marriages. ${ }^{64}$ Rétif's solution, whether sincerely intended or not, is an example of the eighteenth-century vogue for "projecting," that is, promulgating in print rational and often scientific solutions to social problems. Projecting was associated with the rise of policing as population management, and while not detached from enlightened monarchy - in fact, usually calling on the monarch for endorsement and financial support - projecting often presented solutions that we would deem bureaucratic (in Le Pornographe state employees manage the commerce from their offices or bureaux). As opposed to simply analysing mores, social projectors aimed to intervene and to reform them through changes in legislation, policies, and enforcement. Ange Goudar's dissection of and recommendations for Naples, naturally rich but socially indolent, was another such work. It had as its fuller title Naples: Ce qu'il faut faire pour rendre ce royaume florissant. Où l'on traite des avantages que le gouvernment peut retirer de sa fertilité, de l'abondance de ses denrées, des facilités pour perfectionner les arts: de sa position favorable pour s'emparer des premières branches du Commerce Étranger, \&c, \&c. (What must be done to make this kingdom flourish. Wherein are treated the advantages that the government might draw from its fertility, from the abundance of its produce, of its aptitudes for the perfection of the arts, of its favourable position to take hold of the foremost sectors of foreign commerce, etc.).

As Sade continued to labour over the Italian manuscript after his return to France, he considered the genre of projecting as a possibility, setting out a plan for a book he would call "Project for a Reform in Italy." But in a marginal note by this title, Sade writes instead: "I will entitle this piece General Reflections on Italy and place it at the head of the work, after the preliminary discourse." Perhaps these diminished aspirations resulted from his realization that such an undertaking had already appeared as Di una riforma d'Italia, ossia dei mezzi di riformare i più cattivi costume e le più pernciose legge d'Italia (Concerning a reform of Italy, or ten means of reforming the most harmful Italian customs and its most pernicious laws) by the philosopher Carlo Antonio Pilati (1733-1802) and published in 1767. Pilati's treatise was soon translated, and appeared in French two years later. Sade took notes - or rather, extracted literally - from the work as he was preparing his own manuscript. ${ }^{65}$ Or maybe he simply did not have the inclination or energy for this sort of writing. Although Sade continued to labour on the Italian manuscript in prison, he became increasingly despairing that his efforts would bear fruit at all. At the top of a notebook full of excerpts and passages, Sade penned that the material was gathered in 1777 and that it "might be used for my work that I will likely never do." Yet throughout his journey and subsequently, as he continued his research and writing on Italy, our marquis was, surely unbeknownst to himself, gathering material that would deeply inform his licentious fiction. This included notions of projecting and reform, albeit perversely twisted.

\section{The Italian Vice}

Godfrey IV, the Hunchback (1040-1076) was the estranged husband of the indomitable Matilde di Canossa (1046-1115), Margravine of Tuscany. He met his end in a peculiar manner one winter's day. Godfrey had gone to relieve himself when "an arrow pierced him 
through the anus," an injury from which he died a few days later. Sade read about this incident in a 1756 book by the playwright and prolific editor and commentator Charles-Hugues Le Febvre de Saint-Marc (1698-1769), with the title Abrégé chronologique de l'histoire générale d'Italie (Chronological summary of the general history of Italy), and the latter, in turn, had drawn on Delle Antichità estensi ed italiane (Concerning the ancient history of the House of Este and of Italy) (1717-1740) by the historian Ludovico Antonio Muratori (1672-1750). Sources varied as to who exactly was responsible for Godfrey's assassination, with Muratori arguing that it was carried out on the orders of Robert, Count of Flanders, and others that the guilty party was ultimately Matilda herself. Sade does not commit himself to a position on exactly who was responsible, but he is certain about the manner of the assassination: "You have to admit that this is a very Italian way to put someone to death." This was witty allusion, if not in the best taste, to the supposed peninsular penchant for sodomy. The term at this time generally referred to anal sex, although it was not restricted by gender and included both what a later age would deem homosexual and heterosexual acts. In the infamous Sonetti lussuriosi (Lascivious sonnets) (c. 1526) by Pietro Aretino (1492-1556), a woman entreats her lover in no uncertain terms: "In cul lo voglio [I want it in the ass]." ${ }^{\prime 66}$ Sodomy is demanded and desired as proof of passion, although the man responds with qualms - he has no taste for committing this sin, which he deems "prelate's food." ${ }^{67}$ Aretino's satirical pen cuts in two ways here, humorously skewering both the protocols of courtly love and also clerical hypocrisy. Similar jests will be found elsewhere in obscene early modern Italian satire, for example, La Cazzaria (c. 1525) (The Book of the Prick) by Antonio Vignali, where friars are characterized as "rogues [...] devoted to buggery," and Aretino's scurrilous dialogues, the Ragionamenti (Arguments) (1534-1536). ${ }^{68}$ Although literary invocations of sodomy helped spread the Italian reputation in France and beyond, these were entangled with complicated realities.

In eighteenth-century France, sodomy was considered a pan-Italian predilection, and Florence's reputation was particularly robust. This was based, in part, on aristocratic conventions in the city, where in early modernity, male erotic attachments were tolerated and to an extent sanctioned during the period of gioventù or youth, which could be a capacious category. ${ }^{69}$ On the less refined end of the spectrum, Florence was also known for a lively tearoom trade of sorts, which went through periods of both relative openness and suppression. Sade knew of these cycles from his reading of a 1754 French translation by JeanBaptiste Requier (1715-1799) of the extensive Storia fiorentina (Florentine history) by the historian and poet Benedetto Varchi (1503-1565). ${ }^{70}$ Written in the middle of the sixteenth century, Varchi's account was sufficiently unvarnished and provocative that it remained unpublished until 1721. Sade in his preparation of the Italian manuscript made extracts. He noted, for example, that when Niccolò Capponi (1472-1529) was elected gonfaloniere of justice in 1527, he "reformed mores" and specifically "renewed punishments enjoined for sodomy, which was ever the predominant vice of the nation." Where did matters stand in the later eighteenth century? The Florentine reputation certainly lingered, to the point that some writers thought refutation was in order. Lalande, in his guidebook, remarks that sodomy was no longer prevalent in the city. Explicitly contradicting him, Sade judges the practice to be "still very much in vogue in Florence, above all among the priests and monks." Whereas Sade considered prostitution in Florence to be relatively well regulated and topographically restricted, here he adds a concern about the public character of male sodomitical comportment: "In the street in the evening, the partisans of this debauchery display themselves with all the more insolence insofar as women are almost never present 
then." Not that Sade thought that sodomitical desires were not aimed at women as well and he suggests that women themselves were only slightly less willing to indulge than Aretino's impassioned lady. He writes of "an old law in Florence, the execution of which is doubtless shrouded in mystery, but which I am assured is of quite ancient provenance":

This law holds that wives, on Fat Thursday, must accord everything to their husbands, without any restrictions, and in case of refusal on their part, the latter can constrain them to submit. A joker claimed, on this topic, that carnival was quite long in Florence or that one had never had much trouble in forcing them to do so. [original emphases]

To explain the toleration of "all vices of impurity" in Florence, which include "incest, adultery, masculine and feminine sodomy," and more, Sade is referred to - and accepts the influence of a fundamental means of accounting for the variety of national mores: "The climate, say the upright Tuscans most phlegmatically, excuses our penchants and God who had us born therein will take no offence at the excesses to which the climate impels us" (original emphases). Sade concludes: "Such a law, in our more temperate climates, would perhaps please some depraved husband, but I doubt that we would find as in Florence wives disposed to submit without repugnance." Perhaps he had Renée-Pélagie, his otherwise forbearing spouse, in mind.

If sodomy in Italy was a long-standing and likely ineradicable proclivity, Sade could point to numerous examples. He had witnessed poor young girls and boys offering themselves up to such treatment on the streets of Naples - a supply that implied demand - and he was also aware of literary history. The modern propensity appeared to be an extension of attitudes and comportments associated with decadent Rome and more particularly ancient Greece, the culture of which had indelibly marked the former. Greece provided not just a model of actual and institutionalized behaviours but also a rich literary and iconographic tradition. Examples mentioned in Sade's manuscript include the tenuous tradition that young Achilles had a pederastic relation with his tutor, the centaur Chiron - a relation that Sade leeringly hints at while contemplating a painting of the pair uncovered at Herculaneum - to Jupiter in the form of an eagle carrying off the handsome boy Ganymede, a name that would become a byword for adolescent passive male sodomites (see Plate 1). Sade remarks of a painting by Michelangelo di Lodovico Buonarroti Simoni, usually known as simply Michelangelo (1475-1564), of the latter subject in the Palazzo Giustiniani in Rome that "the master of the gods [...] was starting to get bored with the simple pleasures of the fair sex." The sexual exploits of Roman emperors likewise provided numerous examples of an enduring Italian trend. Take Heliogabalus (c. 203-222), whose biography by Lucius Cassius Dio (c. 155-c. 235) Sade mentions and who had a penchant that Sade dismisses in a manner that we can only find suspect given his own apparent tastes, namely, the emperor's "bizarre mania of only wanting to enjoy the pleasures of love as does a woman." There were also many high-profile and modern examples of sodomites and pederasts that Sade came across in his research. Benedetto Varchi himself, for instance, was a well-rounded humanist who in addition to his celebrated history of Florence wrote amorous sonnets to boys. He was convicted of pederasty in 1545, although the grand duke Cosimo de' Medici (1519-1574) subsequently pardoned him. There were politicians and princes as well. It had not been long since the alcoholic Gian Gastone de' Medici (1671-1737), last of his line to hold the title Grand Duke of Tuscany, enjoyed a dubiously close relationship with his valet de chambre and confidante, Giuliano Dami (1683-1750), and cavorted almost openly with 
a gaggle of young men and boys, known as $i$ ruspanti after the ruspo coinage in which they were paid for their services. ${ }^{71}$ Sade slyly hints at Gian Gastone's behaviour in the chapter on Florence and notes in the margin simply: "He was accused of pederasty." Granted, not all of the examples that Sade mentions are Italian. Concerning the seventeenth-century Flemish artist Jerôme Duquesnoy (1602-1654) - Sade confuses his first name for that of his more famous brother François (1597-1643) - our author remarks that "he excelled mainly in bas-reliefs and in the arabesques required by groups of angels or cherubs" and that "obliged by his work in this genre to make use of young boys that he had stripped bare and placed into poses necessary to him," was inflamed by their beauty, and "the artist dared surrender himself to a philosophical curiosity the unfortunate experience of which has often made so many proselytes." Duquesnoy, who made his name in Rome, was convicted of sodomy while undertaking a commission in Ghent and was executed for his crime.

Many of Sade's examples involve the prelates' supposed tastes and allow him to indulge in philosophical critique. Papal history provided a banquet of intrigue, violence, and debauchery, including sodomy. Sixtus IV, pope from 1471 until his death in 1484, was lampooned in his own era for debauchery, including "effeminate couplings." 72 Sade reiterates accounts that this pontiff not only sanctioned a brothel district in Rome where men could seek out women but also, seeing that "this licence might at best satisfy a third of the capital," figured out a way to please sodomites as well. After all, the pontiff worried that "more dainty dishes" were needed for aristocrats and hierarchs, "that throng of benefactors and men of the Church, the Monsignori and the cardinals." For the wealthy and well placed, "folks bored with the ordinary pleasure and whose taste or the disadvantages ever to be feared when associating with the fair sex" - disease, pregnancy, or both - visiting "the newly instituted quarter" was not an option. To offset this concern, the licence further sanctioned permission during the summer months, when the heat drives male passions to such a degree that women alone could not satiate them and whose "physical structure," in any case, "did not fulfil these nor satisfy them all," for every man to "exercise as he pleased the natural taste that Italians have for sodomy." Sade drew here on Bayle's Dictionnaire historique et critique, and he rightly disputes accounts that Sixtus IV actually signed such a permission. Sade thinks it probable that this supposed permission was an inside joke between the cardinal of Santa Lucia and the pope. He finds the real permission unlikely on several grounds, explaining:

Devotees of this crime, the impetuosity of which we are familiar, are neither folks who would be satisfied with three months nor folks to go and ask for permission, and it is incredible, whatever morals we suppose of a pope, to imagine that he would allow this crime. A debauched sovereign can indulge everything - he can tolerate his errors even in others, if you like - but will certainly not authorize them.

Sexual drive was generally esteemed both strong and unruly in the eighteenth century. Jean-Jacques Rousseau (1712-1778), for example, stated that of all the passions that move us, "there is an ardent, impetuous one that renders one sex necessary to the other; a terrible passion that braves all dangers, overcomes all obstacles, and that, in its fury, seems fitted to destroy the human race it is destined to serve." 73 Sade, ignoring the procreative end that Rousseau thought paradoxically at risk, emphasizes the particular impetuosity of sodomitical fervour. Besides, any ruler, be he king or pope, can use his position at the top of the hierarchy to act with an impunity not extended to others. 
Religious sequestration provided another such avenue of indulgence, offering physical shelter from the public gaze and a veneer of moral sanctity and abstinence. In philosophical discourse, claustration was also critiqued as dangerously repressive. Sexual urges run strong and deep, and attempts to stop them up would only lead to hypocritical subversions at best and dangerous perversions at worst, either exacerbating whatever strange passion might already be in place or encouraging the same in those not otherwise inclined. In Diderot's La Religieuse (The Nun), for example, various mothers superior turn out to be hysterical, lesbian, or sadistic, and the younger nuns, easily corrupted under the circumstances, tend to follow suit. ${ }^{74}$ With its robust Catholicism such distortions were thought to be a particular national problem for Italy, although Sade remarks on the issue in France as well. He comments about a Benedictine convent that Pope Julius II (1443-1513) had transferred to Rome in order to protect the inmates from the depredations of soldiers during the conflicts of the sixteenth century and where the dormitories were fitted with transom windows that communicated with the abbess's apartment, so that "she could see whether anything indecent went on during the night." And he adds: "You will see the same thing in the abbey of Saint Victor of Marseilles, albeit there we are talking about men." Similarly, he remarks that Pope Benedict XII (1285-1342), of French extraction and elected in 1334, repressed the practice of having "young Ganymedes [...] in the service of the abbey of Cîteaux." This time Sade adds: "Doubtless, having been a member of this order, he was familiar with this indecency, and he thought it necessary to repress it, doubtless in order better to hide his own dissoluteness." Wondering why Italian sovereigns have allowed them to exist, Sade bemoans the "amount of abuse [...] born of this encloistered vermin." Why "compel millions of useless men to vegetate in divisiveness and criminality, in the middle of a cloister, asylum for every dissension and for all those infamies held in utmost horror by nature and by reason"? What Sade has in mind, or so he says, is that in Naples, superiors of these institutions must forbid "not the girls [...] but the young boys from entering into the monasteries." Such precautions and pronouncements, however, are useless.

Rarely does Sade offer a glimpse of his personal interest in these matters. Once, concerning the depiction of a Cupid, he jokes that the lovely boy "is almost pretty enough to make one forget about his mother." Yet he does develop a line of critique that undercuts the philosophical argument that sodomy and related behaviours are fundamentally unnatural and primarily the effect of the institutions in which they are embedded. This more accommodating line of criticism was not uncommon in more libertine expressions such as Thérèse philosophe. Having decried monastic and other clerical abuses, Sade goes on to say that he is not claiming to be a "defender of morality [apologiste des mours]." On the contrary, the concomitant of philosophical insight - which targets hypocrisy and harm - is a worldly wisdom that sexual drives in whatever form are natural and ineradicable, that passions are precisely irrational and something that we, in a sense, suffer rather than choose, and that for these reasons the most reasonable path is toleration rather than persecution:

Exceedingly philosophical on this score, I am familiar with the errors, the passions, the tastes of men, all moulded from the same clay. I know that we are the masters of nothing, and that a given obsession that such and so finds repugnant is often the sole object of another's delights. It is not therefore the thing that I condemn in itself; but what revolts me is the pride and the intolerance of these enfrocked men, who while wanting to raise themselves much higher than us, nonetheless share the same weaknesses of nature, are soon enough forced to put themselves at the same level, and this by the impetuosity of the same needs. [emphases added] 
Unforgivable are not the acts themselves, but the hypocrisy and harm inflicted when drives beyond our control are denied. The clergy could be granted indulgence in Sade's view if only they were open about their wishes and comportment. Sade is even more tolerant with respect to artists. He defends, for example, the "philosophical curiosity" of the pederast Duquesnoy and suggests that the sculptor's actions merely revealed a dedication to his art and should serve as a "proof of good morals" in this regard, underscored by his avoidance of women qua distraction. Sade jeeringly charges Duquesnoy's persecutors with superstition. Confusing the "noxious emanations of Sodom" and the "the lake of sulphur that engulfed" the cities of the plain as divine punishment, they see fit to imitate "heavenly wrath" in the form of "human justice" and to immolate an artist who simply employed "little boys for something other than arabesques." Duquesnoy was prosecuted and executed, as already mentioned, but Sade concludes that "altars should rather have been raised" to the artist honouring "the sublimity of his genius and the lightness of his precious chisel." For the average run of men, "never will great talents serve to excuse petty faults." The "zealous" may not understand the calculus at work here, but the philosophical know how to weigh the true value of such talents, credit the difficultly with which they are developed and perfected, and discount any supposed moral transgression accordingly.

Given his biography, Sade's defence of sexual "errors" should not come as a surprise. An intent to commit the crime of sodomy was part of the proceedings related to the Jeanne Testard affair and was a salient feature of his Marseilles adventure. Sade's leanings were remarkably "Italian," and then some. As with his view on the death penalty, we should not, however, reduce Sade's position to self-serving justification. Surely, when he defended as peccadillo at worst the actions of an artist such as Duquesnoy, he was in part defending himself. Likewise, when Sade condemned clerical hypocrisy on sodomy, he was in part demanding why a certain class of men could act with relative impunity and yet insist on condemning others for the same desires and deeds. We may also wonder whether the actions that forced Sade to go on the run were driven by libertine discourse or whether the latter served to justify and explain his actions and desires. The answer is certainly that libertine discourse and Sade's inclinations mutually informed and shaped one another. There was no way that Sade in the printed and public forum that he imagined for his Italian project could have simply announced or endorsed his sodomitical interests. But that he had these interests - or at the very least he had a "philosophical curiosity" that extended to sexual variety - is clear, and Italy was for the various reasons laid out above a good place to think about them. Twenty-odd years after Sade drafted his Journey to Italy, his heroine Juliette would encounter in regular and boring Turin her first Italian procuress, who inquires concerning her flexibility:

"And the ass, my lovely queen?" said signora Diana to me, "And the ass? This is what is quite sought out in Italy; you'll earn more money with your ass in a month, if you lend it, than in four years, if you only proffer your cunt." 75

Sodomy ever held sway as Italy's favourite vice, at least in the mind and fiction of the Marquis de Sade.

\section{The Virtuoso}

In Sade's era, there were two main branches of philosophy as a general, non-partisan term: moral philosophy and natural philosophy. Moral philosophy focused on social relations, 
ethics, and what would eventually be deemed epistemology, while natural philosophy encompassed zoology, geology, chemistry, physics, and so forth. As with epistemology, "sciences" was a later rubric, and when that term was used in the eighteenth century, it simply meant various types and branches of knowledge. To be learned in this period in France meant aspiring to a broad exposure to natural philosophy, at the least. If one could not claim expertise, one required at a very minimum curiosity, to conjure one of the key positive values of the era. No longer suspect as a source of sin, curiosity, as the philosopher and intellectual historian Hans Blumenberg (1920-1996) has argued, was in early modernity undergoing a thorough rehabilitation. ${ }^{76}$ It was a rehabilitation on which Sade was playing, dangerously, with his extension of "philosophical curiosity" to an interest in criminally liable actions such as sodomy. As an adjective, "curious" was increasingly applied with approbation both to people and to phenomena and objects worthy of attention. Since the sixteenth century, collections of minerals, shells, animal skeletons, and preserved specimens had been set aside in natural history cabinets, dedicated rooms that were the precursors of natural history museums. Also included in such collections were artefacts such as coins, weapons, and antiquities. Broadly, these came to be known as "cabinets of curiosities" in English and in French by the cognate cabinet de curiosités. ${ }^{77}$ In German, they were called, similarly, Wunderkammern (wonder rooms) or Kunstkammern (arts and artefacts rooms). An important early example is the Kunstkammer in Prague that belonged to Rudolf II, Holy Roman Emperor from 1576 until his death in 1612.

Such regal collections became de rigueur, and increasingly private citizens of means and taste would amass and display various items of interest. By the early seventeenth century, readymade cabinets of curiosities were available for purchase. ${ }^{78}$ The eighteenth century only witnessed an expansion of such collections, among which we can include the British Museum, where William Hamilton's Italian artefacts wound up. Early in his journey, Sade notes that the natural history cabinet of the Prince of Modena - the Duchy of Modena and Reggio was an independent state at the time - was well worth a visit. In Florence, he remarks that the current grand duke, Peter Leopold, was then in the process of creating a natural history collection. Sade points out that although the anatomy section, "all in waxwork, is pretty and complete," the collection would benefit from the addition of works by a local surgeon named Giuseppe Galletti (1738-1819), who in collaboration with the sculptor Giuseppe Ferrini (dates uncertain) and subsequently Clemente Susini (1754-1814), had produced models of "all the different modes of childbirth" and one of a nine-month-old girl that could be disassembled (see Plate 2). Doctor Mesny, Sade's main contact in Florence, had a renowned private cabinet of natural historical and other curiosities, and his correspondence with Sade makes it clear that he was hoping that the Count of Mazan on his travels in the vicinity of Naples might locate some additional items for it. ${ }^{79}$ Touring presented a prime opportunity to begin or augment a collection of curiosities, and the chests that Sade had shipped to France from Naples would presumably have been the basis of his own cabinet. ${ }^{80}$

Sade was well aware that curiosity, an inherently positive value, might have unintended, deleterious effects on sites of historical and natural interest. He believed that collecting, in particular, undermined the value of touristic experience and suggested that conservation would be better served through levying fees. Unfortunately, proprietors tended to discount the potential for long-term revenue and to shortsightedly yield to the temptation of immediate profit: "a tolerant attitude all the more poorly understood on the part of the owners since curiosity diminishes in relation to the destruction of the objects that excite it, and so they will imperceptibly lose the very product that allows them legitimately to tax that curiosity." 


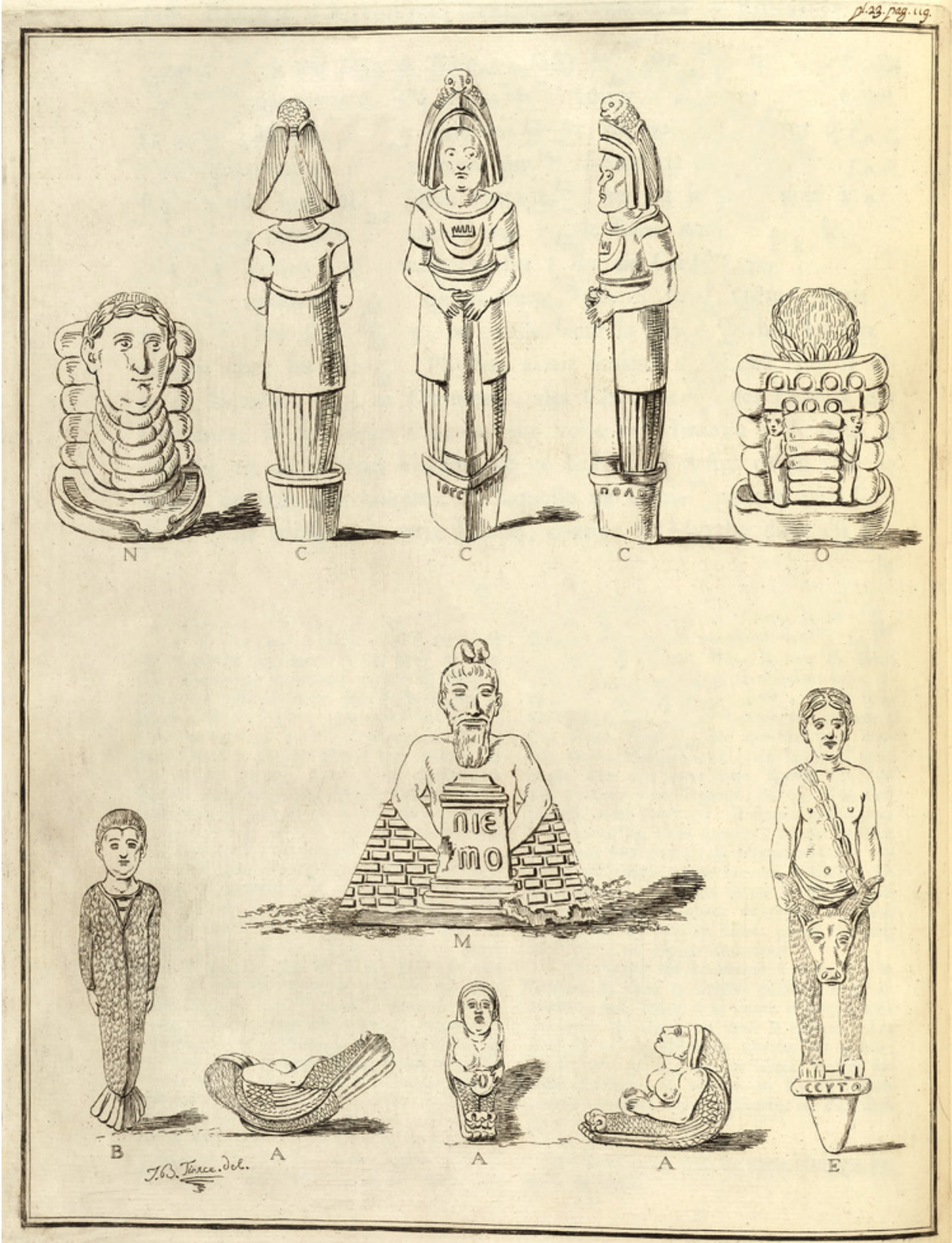

Figure 0.2. Etruscan figurines in Doctor Mesny's cabinet of curiosities, from William Hamilton and Pierre-François Hugues d'Hancarville, Collection of Etruscan, Greek and Roman Antiquities from the Cabinet of the Hon. ${ }^{\text {ble }} W^{m}$ Hamilton, His Britannick Maiestys Envoy Extraordinary and Plenipotentiary at the Court of Naples/Antiquités étrusques, grecques, et romaines tirées du cabinet de M. Hamilton, envoyé extraordinaire et plenipotentiaire de. S.M. Britannique en cour de Naples, vol. 3 (1766). 
Sade's concerns here were not only about the dangers of the commodification of curiosity. He more often points out the damage inflicted to Italy's ancient patrimony because of superstition, which "every day deprives the curious of a thousand precious pieces," with nobles as well as the Church elite repurposing antique marbles, columns, metals, and so forth to tastelessly recreate an Imperial luxury to which they can never hope to truly obtain. Generally speaking, the modern Italians of the Christian era are simply the latest Vandals.

The rehabilitation of curiosity went hand in hand with the development of empirical methods. Geology was a fast-growing field in the eighteenth century, and Sade, like many other grand tourists and learned readers, was particularly intrigued by geological oddities as evidence of the dynamism of the mineral kingdom. In Europe, moreover, Italy stood out for possibilities of experiencing and studying volcanic activity. Sade's first such foray comes early in his voyage, when he explores the vicinity of Pietramala in the Piedmont. Here gaseous emanations can be set aflame and rainwater that pools at this spot appears to boil and yet somehow remains cool. Sade describes the composition of the soil and other aspects of these phenomena, although he does not go into much detail. When Sade visits the Lago dei Tartari and an adjacent lake on the route to Tivoli, however, he not only observes that these waters have "petrifying powers" and that the "sports of Nature" thereby produced are sought after by collectors for their cabinets, he also lays down an extended hypothesis about the process of petrifaction. The vicinity of Naples, with its abundant volcanic activity, provides Sade ample opportunity for observation and speculation - from the hot springs of the island of Ischia to the fumaroles of Solfatara near Pozzuoli and the toxic emanations of the Grotta del Cane on the shores of Lake Agnano. The latter was a well-known stop on the grand tour and long featured in guidebooks. Indeed, Pliny the Elder (23-79 CE) describes the spot in his Natural History. ${ }^{81}$ The name, meaning "cave of the dog," derived from the practice of demonstrating for curious visitors the debilitating and at times deadly powers of this shallow cavity on canines. The expérience du chien or "dog experiment," as characterized in Les Délices de l'Italie (The delights of Italy), an early eighteenth-century guide and compendium by Alexandre de Rogissart (dates uncertain) and others, worked like this: a dog is brought into the grotto; the person carrying the creature is not affected by this operation, since the emanations dissipate with elevation; the dog is lowered to the ground, convulses, its eyes roll back, it stretches on the ground, and stiffens. At this point, the animal is tossed from the cave, plunged into the nearby lake, and it swims forth, whimpering with joy. ${ }^{82}$ Dogs were merely customary victims. Accounts in the eighteenth century claimed that when Charles VIII, called the Affable, of France (1470-1498) visited after his conquest of the Kingdom of Naples in 1495, he put an ass to the test, killing the beast. After the French had been driven out, Don Pedro of Toledo (1484-1553), the imperious Spanish viceroy of the kingdom in the early sixteenth century, was said to have made two slaves undergo the treatment. They convulsed and could not be resuscitated. ${ }^{83}$

The basic procedure seems to have changed little, if at all, by the time of Sade's visit in 1776. Yet while earlier trials at the Grotta del Cane were certainly curious, by the middle of the eighteenth century, they had become more methodical, scientific, and sceptical. For example, Alexis-Jean-Eustache Taitbout de Marigny (1695-1778), French consul in Naples, wanted to know whether the final step - the reviving plunge of the dog into the lake - was necessary. After experimentation, he concluded that it was not. On the contrary, the plunge risked drowning the creature instead of reviving it. In 1745, the consul reported his findings to the Académie Royale des Sciences in Paris, France's chief learned 


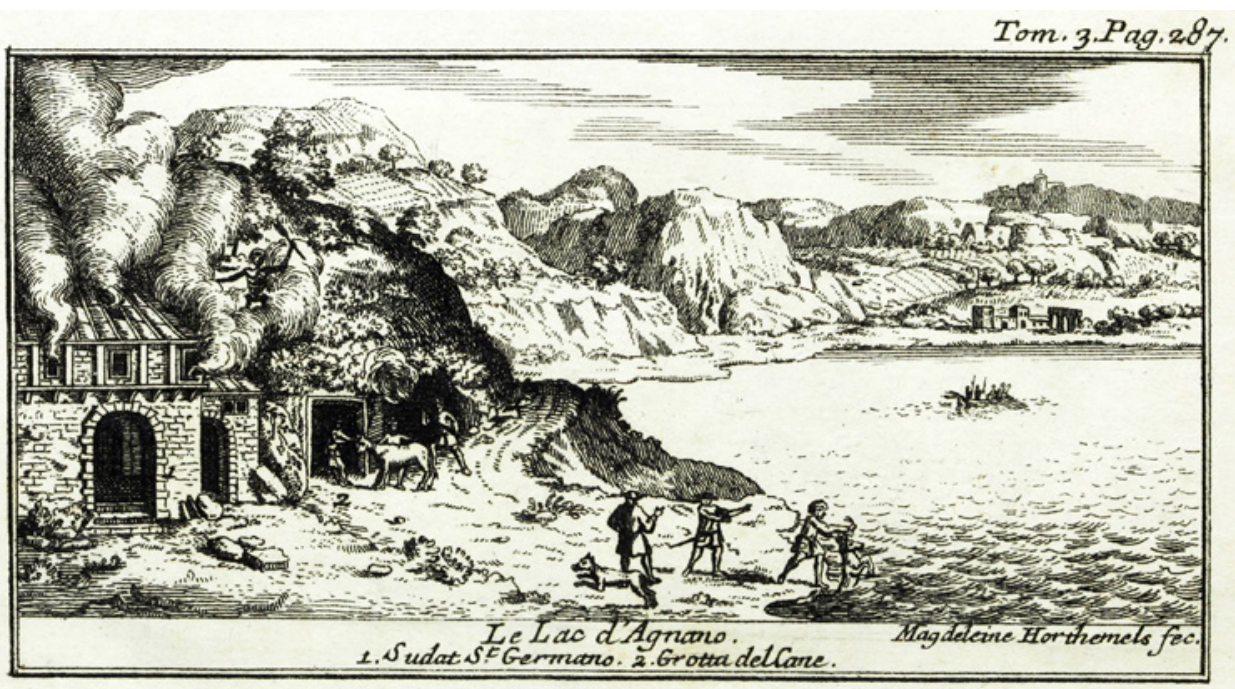

Figure 0.3. Grotta del Cane and Lago di Agnano, from Alexandre de Rogissart et al., Les Délices d'Italie (1709).

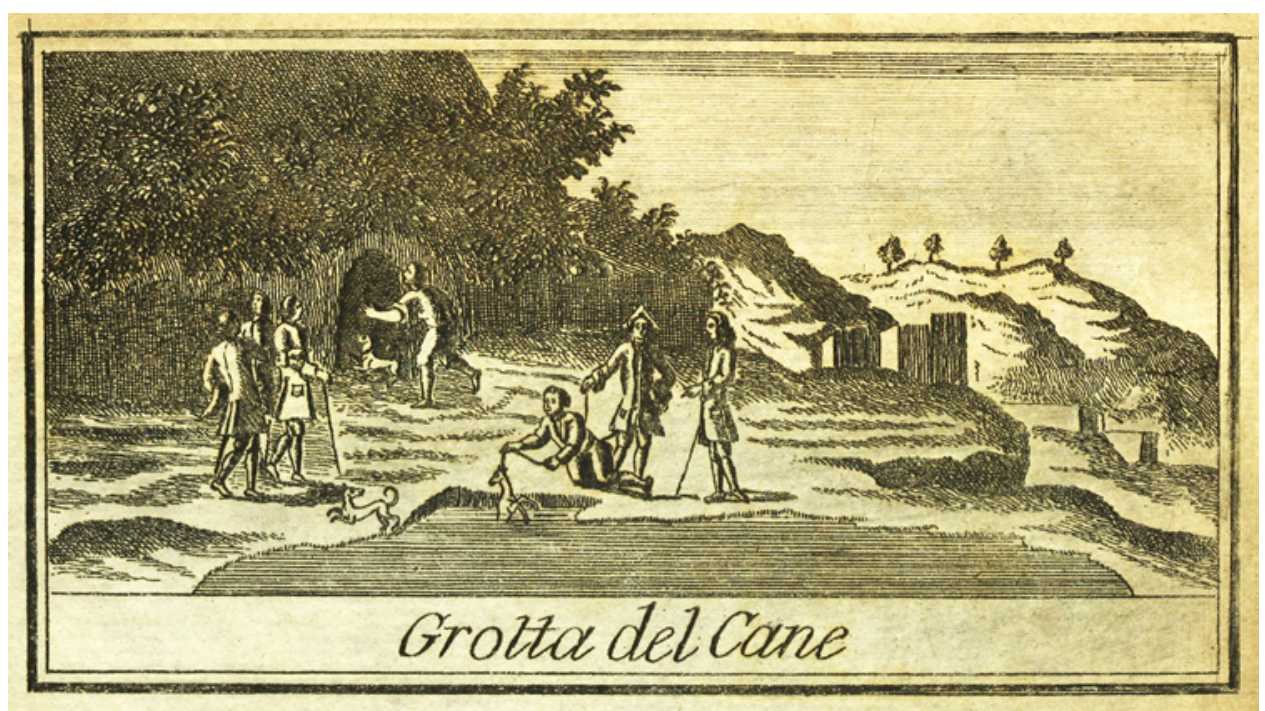

Figure 0.4. Grotta del Cane, from Pompeo Sarnelli, La Guida de'forestieri ... di Pozzuoli (1769 ed.).

body, which published them in its annals in $1749 .{ }^{84}$ A pioneering researcher in the field of electricity, Jean-Antoine Nollet (1700-1770) was consecrated as a deacon in the Roman Catholic Church in 1728 and sought permission to preach, but soon after abandoned his clerical career for one of scientific research and education - yet he apparently enjoyed being referred to as abbé Nollet for the rest of his life. During his tour in the area, Abbé Nollet undertook several experiments in situ. These included testing the temperature of 
the water in the cave (a warm 29 degrees Celsius, whereas the ambient temperature was a moderate 18); placing a candle therein and noting the effects (it was soon extinguished); and placing a dog therein for three minutes and noting how long it took for the creature to revive (two minutes). Nollet did not simply observe, he also carefully took measurements and manipulated variables. He thus tested out the effects not only on a dog but also on a rooster, which vomited up its final supper and promptly expired. Frogs, flies, and beetles survived longer, just as they did when placed in the vacuum of an air pump (one of the crucial experimental machines of the early empiricist era and useful for pedagogical scientific demonstrations ${ }^{85}$ ). Nollet also personally entered the cave to suffer its emanations. He reported his findings to the Académie Royale in 1750, which published a summary of his experiments along with his detailed account of the grotto in 1754. In conclusion, Nollet reported that the vapour in the cave contained no inherent toxin, such as arsenic, but rather was either "not at all air" or "not at all an air similar to that of the atmosphere" and that animals exposed to it succumb "not as empoisoned, but merely as if drowned in a fluid incapable of supplying the air that they are lacking." 86 Along the same lines, one of Sade's competitors in the Italian guidebook business, Lalande, brought back to France "some earth, water, and saline materials" gathered in the cave. He asked a scientist for an analysis, who found no toxins such as copper and arsenic present. These findings, too, were reported to the Académie Royale and subsequently published. ${ }^{87}$ As it turns out, Nollet's hypothesis that the pernicious power of the cave was not a suspended toxin but a vapour different from air comes close to the truth: it is simply a concentration of carbon dioxide.

Eager to present himself as a curious and keen observer, Sade relishes chances for scientific speculation. Although he does not use the term virtuoso, he presents himself in this guise throughout his manuscript, and in the sense it had at the time: an amateur scientist, ready to forward suppositions about natural phenomena and avid for scientific experience and experiment. In French, there is but a single word for both experience and experiment: expérience. Sade's own description of the Grotta del Cane and his speculations about its vaporous powers add little to learned discussion of the matter, but he did feel the need to present his expérience as such and couched as learned discourse. In this and other moments where natural history is in question, Sade examines the phenomenon, witnesses, hypothesizes, and seeks épreuves, a term that can mean both trials and proofs. Like abbé Nollet, Sade enters the cave himself to feel its effects, and his experimentalist attitude is thus presented as moderately heroic. In other words, Sade highlights both the personal risk and the nonchalance with which such risk is run in the name of curiosity and discovery. Interestingly, Sade also uses the cave to present his sentimental bona fides: a concern for the animals that undergo the trial and do so, unlike him, unwilling and protesting. Sometimes Sade's forays into natural philosophy, and especially his longer hypothetical speculations, come close to unintentional parody. They can elicit a smile and sometimes even a smirk. Long before Sade's Italian journey, Jonathan Swift (1667-1745) in Gulliver's Travels (1726) had mocked the false selfdeprecation and impenetrable jargon of virtuosi, projectors, and their ilk, taking particular aim at those reporting to the Royal Academy in London. ${ }^{88}$ In presenting himself as a virtuoso, our marquis evinces what we might call the philosophical imperative: an authentic traveller in his age must perform empiricism, even if acting the part can seem a bit forced at times.

The same performative mode is all too briefly on display when Sade approaches the acme of the volcanic experience in Italy: Vesuvius, the striking backdrop of the Bay of 
Naples and helpfully proximate to a major urban area. As the grand tour shifted southward in the second half of the eighteenth century, this mountain became a must-see sight. More intrepid travellers might continue on to Sicily and Etna, but Vesuvius maintained its hold on both the scientific and the aesthetic imagination. The most celebrated ancient description of the volcano and its destructive power was the account by Pliny the Younger (61-100 CE) of his uncle's demise in the eruption of 79, which buried Herculaneum, Pompeii, and Stabiae. Pliny the Elder in this telling is a model of curiosity: stoically unconcerned about the risk to his person, driven to understand natural phenomena no matter the cost, and losing his life in the encounter with detachment and dignity. As his nephew explains, "as everyone else was hastily leaving," his uncle steered "his course straight for the danger zone": "He was entirely fearless, describing each new movement and phase of the portent to be noted down exactly as he observed them." ${ }^{89}$ Modern Vesuvius watchers never fail to mention this primordial witness in their own accounts, of which there are many. Giovanni Maria Della Torre (1710-1782) provides an overview of these reports, along with firsthand observations and scientific explanations, in his Storia e fenomeni del Vesuvio (History and phenomena of Vesuvius) (1755). The occasion of Della Torre's book was the lava flow that started in 1751 and another in 1754 that lasted into February of 1755. The Storia e fenomeni was reprinted and updated in 1768, with the inclusion of descriptions of the major eruption of $1767 ; 9^{90}$ it was translated into French, based on the 1768 version, as Histoire et phenomènes de Vésuve (1771). Sade makes brief mention of Father Della Torre in his notes for his manuscript. The 1767 eruption was also the occasion for the most famous eighteenth-century account in English of the volcano and, indeed, a Continental locus classicus, namely, the first-hand and chronologically unfolding description of the event over a number of days as experienced by William Hamilton. Initially presented as a series of letters to the Royal Society, these would be published in 1772 as Observations on Mount Vesuvius, Mount Etna, and Other Volcanoes. Hamilton would subsequently expand his work on southern Italian volcanism to a three-volume set, with colour prints, in his Campi Phlegrcei. Observations on the Volcanos of the two Sicilies as They have been communicated to the Royal Society of London (1776-1779). These volumes, published in Naples, were bilingual: English and French, to maximize Hamilton's reading - and purchasing - public. The first two volumes appeared as a self-contained set in 1776. The third appeared in 1779 with the title: Supplement to the Campi Phlegrcei, Being an account of the great eruption of Mount Vesuvius in the Month of August 1779, Communicated to the Royal Society of London.

Sade's description of the volcano abruptly ends at the beginning of his climb, although he evidently planned to flesh out his description and experience of what he termed "a truly horrible spectacle." We do have notes that he took to this end, although these are full of lacunae. To better understand Sade's attraction to Vesuvius and his attitude to the experience in spite of these gaps, a taste of Hamilton's report of the 1767 event - its sights, sounds, smells, and the feeling of the ground shaking - is illuminating. In describing the spectacular ejection of glowing rocks that were "perfectly transparent, some of which, I dare say of a ton weight, mounted at least two hundred feet perpendicular" prior to the eruption proper, Hamilton emphasizes not only the excitement but the danger: "Mr Hervey, brother to the Earl of Bristol, was very much wounded in the arm some days before the eruption, having approached too near; and two English gentlemen with him were also hurt." ${ }^{91} \mathrm{He}$ immediately elaborates on the mesmerizing sight: "It is impossible to describe the beautiful appearance of these girandoles of red hot stones, far surpassing the most 
astonishing artificial fire-work." $" 92$ As Hamilton along with a peasant guide approaches the mountain for better viewing, a new mouth suddenly opens and threatens him directly:

A fountain of liquid fire shot up many feet high, and then, like a torrent, rolled on directly towards us. The earth shook, at the same time that a volley of pumice stones fell thick upon us; in an instant, clouds of black smoak [sic] and ashes caused almost a total darkness; the explosions from the top of the mountain were much louder than any thunder I ever heard, and the smell of the sulphur was very offensive. My guide, alarmed, took to his heels; and I must confess, that I was not at my ease..$^{93}$

Such were the thrills that Campania's premiere natural attraction promised and occasionally delivered. To make his tour of the vicinity of Naples complete, Sade reports that he decided to climb Vesuvius himself, leaving early in the morning "in order to spend the entire day there and to examine at ease such an extraordinary phenomenon of Nature." The volcano was quiet the day of his visit. There would not be another eruption until the following year, in 1777, with a more impressive one yet in 1779. Notwithstanding, Sade the virtuoso dutifully retraced the steps of Pliny the Elder, and in the introductory commentary that we have of this expedition he does his best to convey the attitude of simultaneous detachment and engagement that led that earlier avatar of empiricism to his death. He also submits that here Nature creates "sports" - freakish or monstrous occurrences - that tend to destruction but that are nonetheless beautiful to behold.

\section{The Tasteful Traveller}

In his description of Vesuvius, William Hamilton mingles the attitudes of detached scientific observation and engaged aesthetic appreciation. The girandoles are fascinating, dangerous, and beautiful. The eruption proper, with increased threat and enhanced spectacle, inclines to the sublime: a "glorious appearance" and "uncommon scene" that "passes all description." 94 The beautiful and the sublime were the two key aesthetic categories in the eighteenth century, eventually to be joined by the picturesque, each with its own array of characteristics. Although the terms had been in circulation throughout the century, the publication in 1757 of A Philosophical Enquiry into the Origin of Our Ideas of the Sublime and Beautiful by Edmund Burke (1729-1797) helped to codify a distinction that would become increasingly rigid. It was translated into French in 1765 and influential on the Continent, yet the 1776 inventory of Sade's extensive personal library at La Coste suggests that he did not himself own a copy of Burke's work..$^{95}$ Beauty was associated with gently curved lines, symmetry, harmony, light, and in the concise neoclassical definition given by the philosopher Francis Hutcheson (1694-1746), displayed "uniformity amidst variety." 96 Sublimity, initially a rhetorical notion, entailed discord, rupture, darkness, and ultimately, the blockage of the perceiver's perceptual and imaginative powers. ${ }^{97}$ Indeed, as Hamilton's narration asserts, the sublime, paradigmatically, lies beyond description. Not that writers and artists eschewed attempts at evoking the sensation in their works. Vesuvius was one of the most painted spots on the grand tour, and visual sublimity along with beauty were certainly the aim of artists such as Pierre-Jacques Volaire (1729-1799), who provided striking examples in his paintings of the eruption of 1771, and Joseph Wright of Derby (1734-1797), who undertook the grand tour in 1773-1775 and painted similar scenes (although he, like Sade, missed a proper eruption). Both deployed contrasts and extremes. Brilliant eruptions of fire 
and bright flows of molten lava served as foils for the obscurity of the mountain and bay at night, cloaked in inchoate clouds of smoke. Inevitably, in such depictions, spectators are placed in the foreground, dangerously proximate to these primordial forces of nature and dwarfed by majestic upheaval (see Plate 3).

In his curtailed description of Vesuvius and throughout the Journey to Italy, Sade employs terms such as "superb" and "magnificent" that point in the direction of the sublime. With greater frequency he applies the adjective "beautiful," and more often than will be evident in translation, where for the sake of variety I have sometimes chosen "handsome," "comely," and other synonyms. "Beautiful" is by far Sade's most common descriptor for paintings, sculptures, buildings, landscapes, spectacles, and events that he deems worthy of positive aesthetic qualification. To be clear, Sade does not employ the term "aesthetics" in this sense nor, in fact, at all. The 1750 publication Aesthetica by Alexander Gottlieb Baumgarten (1714-1762) is commonly recognized as the text that applied the Greek term for sensation to a differentiated field of philosophical inquiry. This work did not register in France, and to this day is better known for its terminological contribution than for its content. Aesthetica was, however, an important background text for Immanuel Kant (1724-1804) in writing his Kritik der Urteilskraft (Critique of the Power of Judgment), which along with insisting on the specificity of aesthetic or critical judgments, further elaborated, codified, and demarcated both the beautiful and the sublime. ${ }^{98}$ The reception of Kant's work was much stronger in Britain than in France, and it was in any case published in 1790, long after Sade was safely back from Italy. There were, however, in French letters in the eighteenth century lively discussions of the nature of the beautiful that could be loosely characterized as aesthetic, including Réflexions critiques sur la poésie et sur la peinture (Critical reflections on poetry and painting) (1719) by Jean-Baptiste Dubos (1670-1742) and Les Beaux arts réduits à un même principe (The fine arts reduced to a single principle) (1746) by Charles Batteux (1713-1780). Dubos's work focuses on the reception of artworks, including literature, and on the spell-binding power of mental agitation. Batteux elaborates the imitation of what was known as la belle nature or "beautiful nature" as the underlying unity of the fine arts. As with Burke's treatise, Sade does not appear to have owned either of these two, although he surely would have known of them.

The details of contemporary debates on the fine arts were seemingly not of particular interest to this otherwise wide-ranging and well-rounded reader. Nonetheless, the preponderance of material in the planned chapters of Sade's Italian project are concerned with art first and foremost, followed by the aesthetic appreciation of Nature, including beautiful vistas and typical sublime settings such as rugged mountain passes and waterfalls. In terms of artworks, what interested Sade most is formulating his judgment of the relative merits and faults, that is, exercising and demonstrating the acuity of his innate but educable faculty of taste. In this regard, Sade's approach differs little from that of Baumgarten and most others who considered that the role of the fine arts critic is to judge whether something is beautiful or not and to state why. Demonstrating and discerning good taste or bon goût was the task of both the connoisseur (someone who knows or has familiarity) as well as the amateur (or lover) of the arts. If Sade often appears petulant and dismissive in his criticism of particular artistic examples and individual artists, we must remember that historical appreciation and open-mindedness were less valued and that criticism or the work of discerning, distinguishing, and judging was understandably expected of critics, even if a certain generosity of spirit was also commendable. But what exactly was taste? An early eighteenth-century handbook on miniature painting for autodidacts, attributed to Claude 
Boutet, provides an utterly standard account of how the term was understood, at least as applied to the art in question:

This is the manner in which the painter treats his subject, in accordance with the idea that he has of each thing; if he has a grand idea thereof, noble, extraordinary, in a word the most excellent imaginable, he will represent it as such; then you will say that what he has done is "in the grand taste." But if he is ignorant of what the beauty of bodies consists of, and he does not represent them in accordance with that beautiful idea that one ought to have thereof; then we will say that this is in "bad taste." 99

This definition is unhelpfully tautological. To have good or even grand taste as a painter is to represent an excellent idea excellently, while bad taste is a failure of conception and of execution. The question remains: how, outside of inborn capacity, is one to develop taste, either as an artist or as a critic? Boutet's response is through "the sight and the study of beautiful nature [la belle nature] and the most beautiful works of the painters who have excelled." 100 Historically speaking, the even shorter answer was: Go to Italy. Italy's varied landscapes were renowned for their picturesqueness, that is, as worthy of representation - the English term and its French equivalent pittoresque both derive from the Italian pittoresco or "painterly." For this reason, southern Italy in particular, with its unkempt natural abundance encroaching on myriad vestiges of Antiquity, drew artists and tourists alike in the latter half of the eighteenth century. Capitalizing on this reputation, the title that Saint-Non gave to his descriptive account of the kingdoms of Naples and Sicily was Voyage pittoresque. There were also, of course, esteemed canvases and frescoes, particularly from the Cinquecento and early Seicento, along with sculptures and architectural wonders both classical and modern. To see these artefacts, travel was necessary. Otherwise, the main expedient was engravings that could only provide a faint notion of the original.

Italy was thus where artists from France and elsewhere in Europe came to contemplate, copy, and sharpen their critical faculties. This expedient was officially recognized in France: the prix de Rome was awarded competitively each year to promising painters, sculptors, and starting in 1720, architects, and it provided fellowship support and lodging at the French Academy in Rome for three years or longer. The academy itself was founded in 1666 during the reign of Louis XIV and was the official institution that oversaw the training of French artists in the city and further afield. The painter Charles-Joseph Natoire (1700-1777), its director since 1751, had just been retired from the position in June of 1775, or mere months before Sade's visit. The new director, Joseph-Marie Vien (17161809), arrived in the capital of the Papal States on 4 November, nine days after Sade. ${ }^{101}$ He was Natoire's pupil, winner of the prix de Rome in 1745, and currently the leading light in the classical revival in painting. Grand tourists were not by and large artists themselves, although they certainly could be. For a trip that was to have significant repercussions for the development of neoclassicism in France, Madame de Pompadour, the famous official mistress of Louis XV, the Beloved (1710-1774) at the time, chose the engraver and art critic Charles-Nicolas Cochin (1715-1790), the architect Jacques-Germain Soufflot (1713-1780), and the literary and art critic Jean-Bernard Le Blanc (1707-1781) as edifying companions for her brother Abel-François Poisson (1727-1781), the future Marquis de Marigny. Poisson departed in late 1749, first spending time at the French Academy. The group then toured extensively. In 1751, Poisson returned to France to take on the position of general director of the king's buildings. This was the position for which he had been 
groomed and that he would hold for over two decades. In 1755, he named Soufflot his chief adviser, and the latter went on to design, among other edifices, the grandiose Church of Sainte-Geneviève in Paris (renamed the Panthéon during the Revolution and given over to the secular worship of French men of letters and artists). The tour also led to Cochin's Voyage d'Italie, ou recueil de notes sur les ouvrages de peinture et de sculpture, qu'on voit dans les principales villes d'Italie (Journey to Italy, or collection of notes on the works of painting and sculpture to be seen in the main cities of Italy), published in 1751, which Sade consulted for information on his own journey.

Although it cannot be said that Sade's library shelves buckled under the weight of theoretical works on the fine arts, he was, nonetheless, a reasonably informed spectator, positioning himself more as an amateur than connoisseur. He employed the established distinctions and conceptual vocabulary of men of good taste, and some familiarity with these will aid the reader who wants to grasp Sade's approach to the fine arts. I will focus here on painting, the branch that Sade spends the most time describing. The handbook account of painting attributed to Claude Boutet reflects accepted notions, dividing the art into four major parts: invention, disposition, drawing, and coloration. The first two terms were borrowed from the rhetorical tradition. Invention simply meant "finding the object that you want to put in a painting." 102 This may seem obvious in the case of portraits or still lives, but in the most esteemed genre of history painting, an artist required ample reading and erudition to cull successfully from history, of course, as well as from literature, myth, and fables. Concomitantly, a critic required learning to judge. Still in the category of invention, artists would also need to consider whether objects, beyond simply representing themselves, would serve as symbols, allegories, or emblems. Disposition meant the fitting distribution of figures, the "judicious choice of postures," and ideally "giving to each thing its situation in the place that is most appropriate to it." The rhetorical tradition insisted on decorum (la convenance or la bienséance in French), which meant suitability of speech to a given situation and audience. ${ }^{103}$ The notion of disposition, strongly articulated in ancient Greek and Roman rhetoric, became a hallmark of French classical drama in the seventeenth century but was also adapted to the visual arts. Together, invention and disposition make up the overarching category of composition and the theoretical aspect of the fine arts.

Practice consisted of two central elements: drawing or design and coloration (in French dessin and coloris, respectively). In the Italian context, the relative importance of disegno and colore had been a topic of intense debate in the sixteenth century, and different centres of artistic production were celebrated for one or the other. Florence was known above all for drawing; Venice for colour. Partisanship on this matter inflected painting and its reception in seventeenth-century France, but by the eighteenth century the two elements were generally treated as equal components. Granted, one might acknowledge the historical contention, and individual artists and canvases might reveal more competence or excellence in a given category. In the handbook attributed to Boutet, we find for the definition of drawing: the representation of the body by "a simple line that marks the contour thereof." 104 The representation of the human body is generally treated as the apex of drawing skill, although the notion was easily extended to include draperie (clothing and fabrics), the representation of architecture, landscapes, and so forth. Drawing required the study of anatomy as well as knowledge of how various passions are expressed, especially on the face. On this topic, the painter Charles Le Brun (1619-1690) had produced an influential essay, published posthumously in 1698, that came with accompanying schematic illustrations. ${ }^{105}$ Drawing also called for the study of classical models, particularly Greek 
and Roman statuary, and for knowledge of geometry to understand proportionality and perspective. Colour, too, was divided into two parts: under the rubric "local colour" went the knowledge of how different colours affect each other in proximity, and chiaroscuro covered the distribution of light and shade. The rendering of flesh (carnation) also fell under the category of colour. Assembled in a particular work, these elements should add up to vérité or "truth." A truthful representation is not an objective rendering of whatever subject, but quintessentially of la belle nature.

Sade uses the expression "la belle nature" at several points in his manuscript, and he overwhelmingly cleaves to this value. Among other instances, Sade invokes the powerful impact of la belle nature to explain Jerôme Duquesnoy's pederastic attraction to his models. That he deems this principle "profoundly unrelated to sex" suggests something along the lines of what Kant would subsequently describe as aesthetic disinterest, although the purported effect on Duquesnoy certainly seems to belie the assertion. This investment in la belle nature is something Sade unthinkingly shares with competitor travel writers such as Jérôme Richard. But that the concept could not explain all forms of aesthetic pleasure was something that exercised deeper thinkers on the fine arts. Following Aristotle's remark in the Poetics that even horrid creatures such as snakes can be pleasing in imitation, Dubos, for one, had argued that things or actions inherently repugnant could please if experienced mediately through artistic representation, which tempers disgust and allows mental stimulation to fill the void of ennui. Even with real spectacles that everyone ought to find horrifying such as gladiatorial combat and public executions, Dubos argues, stimulation may trump aversion. Viewing "the agony of a fellow man who undergoes the rigor of the laws on the scaffold and who is brought to death by frightful torments" causes immediate as well as lingering displeasure, "but the emotive attraction is stronger for many folks than the reflections and counsels of experience." 106 In the course of the eighteenth century, a veritable aesthetics of ugliness would be developed, mainly through the category of the sublime. ${ }^{107}$ Such an aesthetics of the unattractive and off-putting is something that Sade himself would develop at length in his later writings. In the Italian manuscript, we catch only glimpses thereof. When Sade speaks of the "sublime horror" of the cockaigne violence in Naples, he does so with disapprobation, even if we suspect a modicum of spectatorial pleasure. Aesthetic mediation seemingly makes little difference. Sade reacts to the suite of gruesome martyrdom depictions in Santo Stefano al Monte Celio in Rome with understandable and seemingly genuine disgust, although he does succinctly characterize a painting of Saint John's head on a platter by Caravaggio (1571-1610) a belle horreur or "lovely horror." Within the parameters of the beautiful, Sade values above all correction (accuracy). He is generally quite conservative in this regard, not only criticizing compositions, postures, or colours that strike him as inadvertently awkward or otherwise off but eschewing anything maniéré or "mannered" as a fault. If assessment in such terms sounds dry, Sade also praises more sensuous and dynamic characteristics such as agrément (grace) and force (energy and power of expression). In terms of colour, he tends to praise paintings that are frais - a difficult to translate term that usually means "fresh" or "cool," and that I have often rendered as "vivid." Lastly, Sade has an abiding but by no means idiosyncratic interest in carnation and an appreciation for adequate, expressive rendering of skin tone.

To take a pointed example of how Sade employed some of these elements in his criticism, consider his assessment of Natoire's fresco of Saint Louis in the church of San Luigi dei Francesi in Rome, which the artist had undertaken while director of the French Academy in the city. Sade decries the "poor choice of subject," along with the painting's "stiff" draperies 
and "incorrect" drawing. He also thought the composition hardly benefited from proximity to so many masterpieces. Sade was happy, nevertheless, to praise Natoire's "social virtues," separating the art and the artist from the man. It should be noted that Sade's rejection of mannerism and his appreciation of verité does not entail an uncritical embrace of idealism or eschewing a trace of realism - or rather what he calls vraisemblance, or verisimilitude. This was a term that he occasionally applied to painting and that he borrowed from dramatic theory. Indeed, respect for la bienséance and for vraisemblance was the essence of classical drama in France, built out of the Renaissance rediscovery and reception of Aristotle's Poetics - which argued of tragic plots that the poet should prefer "probable impossibilities to improbable possibilities." 108 Invoking vraisemblance, for example, Sade remarks of the portrayal by Giovanni Battista Naldini (1535-1591) in Trinità dei Monti in Rome of Saint John baptizing Christ that there is too much youth and delicacy in the face of the saviour, who looks more like "a pretty girl than a Jew." He similarly judges improbable the flesh colour of a depiction of Mary; she should have been "quite brown." This was evidently also a philosophical jab at European Christians, who would blanch their idols of oriental taint.

Painting is quantitatively the most important branch of the arts in Sade's manuscript, but there is also considerable qualitative discussion of sculpture and of architecture. Sade encounters and comments on statues that were well-known models of pagan antiquity: the Venus de' Medici and the Farnese Hercules in Florence; the Laocoön and his Sons (or the Laocoön Group) in the Vatican in Rome; and many more besides. Sade's journey did not lack for modern masterpieces either, such as Michelangelo's celebrated Pietà in Saint Peter's and the baroque fantasia Ecstasy of Saint Teresa by Gian Lorenzo Bernini (15981680), in Santa Maria della Vittoria in Rome. Many of the terms of painterly discussion could be extended and adapted to sculpture. Accuracy of anatomy and of attitude or posture stood out. Coloration was relatively insignificant. Polychromic sculpture was not only the medieval but also the classical norm, although the ancient practice was not recognized until after the eighteenth century. Modern artists modelled their works on denuded antiques that were deemed somehow purer. Yet the varied tones and patterns of marble were appreciated, especially in columns and inlay, and Sade demonstrates a fascination with the material that suggests possible psychological interpretations. Was his attraction to a venous yet cold and obdurate material somehow symptomatic? This seems unlikely since expression was what Sade and most other critics in his day held as paramount. Consider Jérôme Richard's opinion of Bernini's sculptures. Judging them to be less "elevated" than the sculptures of earlier artists such as Bartolommeo Bandinelli (1488-1560) and the Flemish sculptor known as Giambologna (Jean Boulogne; 1529-1608) and of Baroque contemporaries such as Alessandro Algardi (1598-1654), Richard nevertheless finds Bernini's works "elegant and graceful" and considers the Saint Teresa group to be a model of "expression." Similarly, Sade considers Bernini to be the epitome of mannerism, yet praises him still. He, too, deems "the famous statue of the languishing Saint Teresa about to be wounded by the Angel" to be Bernini's "masterpiece": a moving rendering of passion and a model of accuracy as far as expression was concerned. For Sade, powerful expression could trump other considerations. Or nearly. Discussing Michelangelo's Pietà, the sculpture of Mary cradling the dead Christ, in Saint Peter's, Sade judges that the artist "succeeded in putting so much soul and expression into both of these figures that he almost makes his subject move us, if one could ever be moved by the death of a double-dealer and imposter resting on the lap of a whore." This example comes from Sade's notebook on Rome, and we can imagine that he might have toned down his rhetoric had his publication plans for the manuscript come to fruition. 
Although Sade frequently discusses examples of architecture, both sacred and profane, his observations, on the whole, do not suggest a robust engagement with the secondary literature. He makes no mention in the manuscript of Vitruvius (c. 80/70 BCE-after c. 15 $\mathrm{BCE}$ ), the most important of classical architectural theorists. Based on correspondence related to the Journey to Italy project, he had only second-hand knowledge of the influential illustrations of and writings on architecture by Sebastiano Serlio (1475-c. 1554), the publication of which began in 1537. Similarly, there is no evidence that Sade had direct knowledge of I quattro libri dell'architettura (The four books of architecture) (1570) by Andrea Palladio (1508-1580), which built on Vitruvius and profoundly influenced the classical revival in Europe - a revival that Sade otherwise appreciated. His grasp of architectural terminology is generally solid, however, even if his architectural descriptions include some of the more confounding, occasionally incoherent passages in the manuscript. He once confuses Doric and Ionic orders; this was likely a momentary lapse. He makes no terminological distinction between nave and aisles in churches, but in this he is not alone. It appears that most of Sade's architectural knowledge came from Essai sur l'architecture (Essay on architecture) (1753) by the Jesuit priest and architectural theorist Marc-Antoine Laugier (1713-1769), which included a glossary of terms and illustrative plates. Sade did own a copy of this work, and his descriptions and especially his critical assessments are redolent of Laugier's work and views. That Laugier was a Jesuit could apparently be overlooked when it came to assessing architectural beauty and flaws. To take one case, which comes up on occasion in the manuscript, Sade condemns the use or abuse of pilasters - instead of proper free-standing round columns - which Laugier had likewise criticized at length: "Pilasters are naught but a poor representation of columns; their angles herald the constriction of art, and they deviate noticeably from the simplicity of nature," and so on in this vein. ${ }^{109}$ Sade similarly - if more pointedly attacks the "stupidity of the architect" who, commissioned with the renovation of the Basilica di Santa Croce in Gerusalemme in Rome, "swallowed up some superb granite columns under heavy and massive pilasters that shrink the building and make it quite awkward looking."

Throughout his planned guidebook, Sade makes sure to stress his empirical accuracy by disputing and debunking claims about measurements. Has the length of a bridge, for example, been provided correctly? How could an author such as Jérôme Richard, to mention Sade's favourite but by no means only target of criticism, claim precision and yet err so frequently and so egregiously? Sade also gamely takes sides and sets out to solve a protracted architectural debate: Does Saint Peter's appear smaller and less majestic than its actual size should entail, and if so, why is this the case? Sade's main point of reference on the matter appears to have been Lalande's Voyage d'un françois en Italie dans les années 1765 et 1766, which puts forth the counterintuitive assertion, cited by our author, that the "miracle of the beautiful proportions of Saint Peter's ... is to produce not a single feeling at first sight." Who would perversely deny, Sade derisively opines, "that it is better to be little and appear great than to be great and appear little"? Well before Lalande, the topic of Saint Peter's proportions and impact had been argued, among other instances, in the pages of the journal Mémoires pour l'Histoire des Sciences \& des beaux arts (Memoirs for the history of the sciences and fine arts; better known simply as the Mémoires de Trévoux) between 1709 and 1712, with the architectural theorist and historian Jean-Louis de Cordemoy (1655-1714) taking sides against the engineer, explorer, and polymath AmédéeFrançois Frézier (1682-1773). ${ }^{110}$ 
The matter was still unresolved in the 1780s, when the art historian and critic Francesco Milizia (1725-1798) considered why people still dispute whether Saint Peter's is "even the same size as the cathedral of Milan or that of London [i.e., Christopher Wren's Saint Paul's]" - it is demonstrably larger - and concluded that the problem comes down to the proscription in "modern architecture" of isolated columns, which enhance the impression of size, and the use instead of pillars and blocks, which instead produce buildings that seem "cumbrous, thick, squat, heavy, and small." 111 Milizia concludes that Pope Paul V (1550-1621) had wanted to create something large but had inadvertently ended up with the opposite effect. Sade would hardly have disputed this assessment, which laid the blame not on the architect but firmly on a pontiff and his misguided quest for sublunary magnificence.

\section{Modern Art, Sentimental Aesthetics, and the "Interesting"}

Like his contemporaries, the Marquis de Sade tended to think of history as falling into two broad epochs, the antique or ancient and the moderne. This conception was particularly strong for the history of art. Each epoch included - or includes, in the case of the modern cycles of emergence, progress, peak, and decline. This cyclical view could be inserted, however paradoxically, into an account of overarching progress. Sade will on occasion pronounce a more nihilist version of the cyclical as eternal "monotony": since humanity does not essentially change, a good look at history reveals "the same events repeating themselves, the same crimes, the same virtues, the destruction of some, the rise of others." Generally, however, Sade sticks to the epochal model, and he is quite specific about when the ancient artistic acme took place, which he pointedly situates in relation to the ascension of the first Roman emperor and, secondarily, to the opening of the Christian era, thus between "Augustus, year I and the 30th of Jesus Christ," when "the arts had reached their perfection." By the time of the emperor Constantine, they were in a state of decline, not to truly reappear until the middle of the fifteenth century. Sade is again specific: "the taking of Constantinople by Mehmed II in 1453." Progress in the arts, in a sense, begins anew in Italy at this time, with the Florentine painters Cenni di Pepo, known as Cimabue (c. 1240-c. 1302) and his pupil Giotto di Bondone, known simply as Giotto (1266-1377), mentioned in the manuscript as constituting the first glimpses of what will rapidly become "advances in the arts." Consciously or not, Sade here follows Giorgio Vasari (1511-1574), who recounts the fall of the arts with Rome, their tenuous survival in the Byzantine Empire, and their re-emergence in Italy, in his Le vite de' più eccellenti pittori, scultori, e architettori (Lives of the Most Eminent Painters, Sculptors, and Architects), first published in $1550 .{ }^{112}$ In eighteenth-century France, this view was simply a historiographical given. The Academy of Dijon assumed that everyone would understand what was meant by "re-establishment" when they posed the question in 1749 whether the "re-establishment of the sciences and arts contributed to the purification of mores" in their annual essay competition. Jean-Jacques Rousseau certainly thwarted expectations when he answered in the negative in his prize-winning response. He repeated the standard narrative, however, when he explained that it was the "stupefied Moslem, the eternal scourge of letters" who, altogether inadvertently, brought about the rebirth of the sciences and the arts: "The fall of the throne of Constantinople brought into Italy the debris of ancient Greece," and "France in turn was enriched by these precious spoils." 113 Adumbrated in Rousseau's telling is the notion of a translatio imperii of arts and letters. In the broadest of terms, the geographical and temporal shift in empires went from birth in Egypt to Greece and especially Athens and on 
to Rome. If Italy was the place of modern rebirth and even perfection, the common French assessment was that Italy's national apex occurred in the sixteenth century and decline had set in by the seventeenth and eighteenth. Needless to say, France had inherited the throne, even if study in Italy was still required. This assumption is often in evidence in Sade's manuscript and was shared by most French writers on the topic. None other than abbé Richard blames misguided religious belief - "bizarre manners of thinking" - as heralding the "decadence of the arts" and shackling "taste and genius" in Italy. ${ }^{114}$ Richard gives as examples the orders from on high to cover Michelangelo's figures in the Sistine Chapel, and the sight of an artist wetting "his palette and brush with tears" as he is forced to censor a painting by Raphael (1483-1520) in which the infant Jesus "appeared too nude."115 Italian artists had once wed classical and pagan appreciation of the unadorned human form to Christianity; whether by inclination or by order, they do so no longer. But as usual, Richard hesitates to indict religion as the root cause and holds that such decline is simply part of the nature of things: "Let's not seek the reason elsewhere than in a certain logic of periodic upheavals [un certain ordre de révolutions], which at times makes the talents of one region pass into another, at times suspends them in inactivity, in a swelling that barely allows us to glimpse the seed in those who seem to make the most efforts, to give them a new existence." 116 For whatever reason, Richard was nonetheless certain that art in Italy was experiencing "a sort of annihilation" and that the revolution had moved on. ${ }^{117}$ On this point, Sade and his principal antagonist are, once again, in perfect accord.

What falls between the ancient and the modern is evidently that nebulous category of the "medieval." Although not a term that Sade employs as such, his conception is clear enough. Sade does not find this period altogether uninteresting, and in the course of his manuscript he does delve into the political and ecclesiastical history of medieval Italy. But he has little regard for art from this era, which he tends to find "more peculiar than pleasing." In describing an arch made to honour Constantine by the Senate and people of Rome on his return from victory over Maxentius, Sade finds that the base, made during "an era when the arts had begun to flee Rome," "already gives off a whiff of the Gothic." The top of the structure, however, belonged formerly to Trajan's arch and was thus built during "a more enlightened [éclairé] century." Sade's nemesis Richard likewise had no regard for "Gothic irregularities," although he also held that for a traveller to appreciate art not only is broad education and an understanding of technical aspects required, but also a willingness "not to confuse the different tastes and epochs." 118 The eighteenth century did witness a halting reassessment of medieval art - both Soufflot and Cordemoy, for example, appreciate aspects of Gothic architecture - and the emergence of the notion that artworks should be judged in relation to historical context; nevertheless, the classicist ideal of Antiquity reborn was still regnant. ${ }^{119}$ Beauty was generally held to conform to universal standards, even as some room was granted for individual, national, and other sources of variation. Relativity of taste or what in the later eighteenth century was characterized in French as caprice was rejected, although radical libertines, including Sade in his licentious writing career, would experiment with exactly this notion as a source of hedonistic variety and flexibility. ${ }^{120}$ In his Italian manuscript, Sade does not yet embrace historical relativity let alone the capricious with regard to art, still he will occasionally describe palaeo-Christian and subsequent church architecture in a posture of learned detachment and not without a suspicion of appreciation.

As for grasping the historical specificity of eighteenth-century French aesthetics, we must note the premium placed on the subjective impact of artworks, landscapes, and literature. At work is a long trajectory that in the seventeenth century witnessed increasing 
interest in the passions, the rise of sentimentality towards the mid-eighteenth, and as physiological theories were increasingly blended in from the mid-century onwards, sensibility as a valued nervous susceptibility to both art and life. ${ }^{121}$ These concepts have been most thoroughly studied in terms of the novel and print culture, where the works of Samuel Richardson (1689-1761) stand out: Pamela: Or, Virtue Rewarded (1740), Clarissa: Or the Story of a Young Lady (1747), and The History of Sir Charles Grandison (1753). Antoine François Prévost's translations of these novels were well known in France. Sade owned all three Richardsons, and they indelibly shaped his libertine writings, which both adopted and inverted the sentimental paradigm and theories of sensibility. ${ }^{122}$

In the visual arts, a sign of good taste is not simply that one nods in approval on account of coloration, design, or accuracy of imitation. Diderot writes in his Essais sur la peinture (Essays on painting) of 1766 that the happy spectator marries "taste" and "sensibility," for the two can be separated. Such a spectator does not "coldly" state that something is beautiful; he is "moved, transported, drunk." 123 According to Diderot, expression is "the image of a feeling [l'image d'un sentiment]." 124 It was valued precisely insofar as the passion depicted was also experienced by the perceiver. But whereas Charles Le Brun was invested in the panoply of human passions, including anger and despair, sentimentality and sensibility in eighteenth-century visual arts tended to emphasize gentle passions such as sympathy, as in the lachrymose canvases of Diderot's favourite, Jean-Baptiste Greuze, and love. Sentimentality was, in fact, usually tinged with an eroticism that ranged from subtle insinuation to open salaciousness. Sade could not help but draw out eroticism in the paintings and sculptures that he viewed, and he often added a dose of philosophical critique. Like many others, he saw something other than divinity at work in Bernini's Ecstasy of Saint Teresa: "The piece is sublime thanks to the air of truth that characterizes it, but one must really firmly set in mind upon seeing it that she is a saint, because from the ecstatic look of Teresa, from the fire that burns in her face, it would be easy to err." Sade smirks about a painting of the Madonna and Child in the church of Sant'Eusebio all'Esquilino in Rome that he would "gladly join the cult of Mary, if such a pretty one were promised me." He adds that all painters in Italy "seem to enjoy giving delicious characteristics to this modern Venus of the Christians." How can pious men concentrate on the Son when the Mother is so enticing?

Sade ties his aesthetic appreciation of such works to another aspect of taste that was never explicitly discussed or formalized but that nonetheless developed and expanded in the eighteenth century, namely, intérêt or "interest." This idea pinpoints what a represented object does to and, after a fashion, for the viewer. It could simply mean "profit," and this sense lingers in the aesthetic context. ${ }^{125}$ The term "interesting" could be and often was used casually and innocuously; however, it also named the linkage of the sentimental to the erotic, where the object of pity is simultaneously the object of desire and even of fantasized violation. Diderot, contemplating a Greuze painting of an adolescent lamenting her dead songbird - a symbol of lost virginity - asks his implied male reader to admit that she is both beautiful and "interesting," and then adds: "I have no love for inflicting suffering; in spite of that, I wouldn't be too displeased to be the cause of her pain." ${ }^{126}$ Known best for his maudlin adaptation of history painting to bourgeois family settings, Greuze also produced frankly lecherous depictions of young girls in dishabille - canvases liberated from the symbolic ambiguity of dead birds. Paintings of the repentant Mary Magdalene, a paradigmatic sexualized sufferer, could elicit similar outbursts of prurient sentimentality. On a Magdalene painted by Louis-Jean-François Lagrenée (1724-1805) and displayed in the Paris Salon of 1765, Diderot would remark that if she anointed Jesus's feet and dried 
them with her hair and he "felt no movement of the flesh," then he was not a man after all. ${ }^{127}$ In the same vein, on a Magdalene by Guido Reni (1575-1642) in the Barberini Palace in Rome, Sade remarks that "this great master has deployed all the grace and truth of his art," and then leering expands that "looking at such a lovely sinner, one would be rather tempted to bring her back to her old errors than those new chimerical virtues that seem to occupy her thoughts!" (see Plate 4). Sade praises the work of Reni throughout the Italian manuscript, and the painter remained a favourite of his throughout his career. Sade's compatriots tended to agree. This artist was known in France simply as Le Guide (rendered "Guido" in this translation, although "the Guido" would be equally apt). The esteem for Reni in eighteenth-century France stemmed from his suitability to sentimental discourse. Reni was the interesting painter par excellence.

Perhaps the most "interesting" work that Sade encounters on his entire voyage is, nonetheless, the sculpture by Stefano Maderno (c. 1576-1636) of the martyred Saint Cecilia, murdered in her bath (see Plate 5). This is not the gut-wrenching gruesomeness of other martyrdom depictions that Sade views with distaste and considers as evidence of Christianity's sanguinary voyeurism. The saint is prone and could perhaps be mistaken as slumbering were it not for the evidence of three slashes: "The marks of her wounds will be seen on her beautiful, completely uncovered neck." Sade judges that the artist has accurately captured the "violent death" of the martyr in the posture he has chosen. He also notes how the delicate drapery of her bathing chemise reveals to the ravished viewer "her contours." It is a delicacy that Sade calls "sublime." Cecilia, recumbent and dead, is nonetheless alluring: "The artist has preserved all the graces of his model and the death that freezes her seems, if this is possible, to only make her more interesting [intéressante]." It is clear she is a corpse, yet "you inhale still all the delicacy and all the svelteness of a young person seventeen or eighteen years old and as interesting as she is pretty [aussi intéressante que jolie]." So "truthful" is Maderno's work that you cannot help but be moved - cannot help but take an interest in the interesting. Sade concludes somewhat inchoately: "I think that such a representation, glimpsed by someone who might have had some lively interest [quelque vif intérêt] in the unfortunate model who might have experienced the same fate, would be liable perhaps to produce a stronger impression still than the cadaver itself. The effect could be dangerous." The implication seems to be that such a sexualized representation of a dead woman might inspire necrophilia, or is it perhaps even murder? Sade excuses himself for lingering over this piece, concluding that Maderno's Martyrdom of Saint Cecilia is "the modern object in Rome that gave me the most pleasure and made me feel a most lively sensation."

A final aspect of what we can broadly characterize as sentimental spectatorship was the appreciation of ruins. A brief consideration of An Essay on the Picturesque, as Compared with the Sublime and the Beautiful by Uvedale Price (1747-1829) will be helpful. Price's book was published in 1794, so it obviously had no influence on Sade's Italian travels. What the work did do was render explicit and help codify an aesthetic category that had long circulated as part of what might be called, loosely following Wittgenstein, the language games of both the arts and travel writing. ${ }^{128}$ For Price, the picturesque, while self-standing, was positioned intermediate to the other two categories: where the sublime favoured ruptures and the beautiful featured gentle curves, picturesque lines broke symmetry but without violence; where the sublime favoured darkness and the beautiful light, the picturesque was dappled and grey. One of Price's crucial examples of the picturesque is processual: a classical structure, white, harmonious, and regular falls into ruin; smooth 
surfaces roughen; columns become encrusted, moss-covered, or entangled in vines. ${ }^{129}$ Ruins were everywhere in Italy, not only adding picturesqueness to painterly landscapes but in the midst of cities, particularly Rome. The remnants of Classical Antiquity were not only objects to be appreciated as models of beauty and magnificence, but also for enjoyably morbid contemplation. As Sade writes of what to expect from a visit to ancient Capua, there you will "consider with pleasure the fragments of its splendour." These ruins were some distance from the modern city, and at the time of Sade's visit, carriages awaited visitors to whisk them off to this site. There were artists who featured such sights and catered to the well-heeled tourist trade. The best-known French artist specializing in the subject was Hubert Robert (1733-1808), a purveyor of "sweet melancholy," to cite Diderot on the painter and what he termed the visual "poetics of ruins." 130 Robert spent over a decade in Rome in the middle of the century, including at the French Academy. He forayed into the countryside in search of material, and in 1760 accompanied Saint-Non to Pompeii. There was also Giovanni Paolo Panini (1691-1765), a vedutisto (landscape painter) whom Jérôme Richard thought a good example of a living Italian artist and who concentrated on Roman antiquities and ruins, often adding fantastic elements. Giovanni Battista Piranesi's engraved depictions of the city and its environs were similar in this regard, and his prints made reasonable souvenirs. How widely appreciated Piranesi was at the time that Sade made his journey, near the end of the artist's career, is unclear. Sade mentions Piranesi only once in the manuscript, and not as an engraver but as an architect and specifically as the renovator of the Church of Santa Maria del Priorato in Rome. Piranesi for Sade is merely he "who has filled this temple with decorations taken from Antiquity but placed haphazardly and presented with a harshness that tires the eyes and will ever displease."

Balancing the insistence on reason and progress, the melancholic contemplation of ruins was an important minor strain of enlightened thought. In depictions of ruins, the artist would often include the figure of a lone tourist or, more commonly still, labourers or peasants at rest or play. This pastoral touch contrasted both civilized complexity with rural simplicity and ancient glory with contemporary decadence. Sade maintains that the modern reality was often less poignant. In the Farnese Gardens on the Palatine Hill, where once the residence of emperors had stood, he remarks that there are "fragments of columns, friezes, pilasters, of great delicacy and singularly precious workmanship." Then, commingling pensive reflection with more than a soupçon of aristocratic disdain, Sade observes that "benches and tables" have been fashioned from these remnants and that "the most vile populace today comes and gets drunk on fragments of the habitation of the masters of the universe." More grandiosely, the contemplation of ruins undermined any notion of progress or the triumph of reason and instead underscored inevitable and universal decline. About the Palatine Hill, Sade writes:

How many sad reflections present themselves to the imagination when we consider what remains of so much grandeur? Some scattered ashes, some bases of crumbling walls - this is all that remains for us today of those proud emperors, which the entire earth did not satisfy, and of their sumptuous abodes. Death and time have not respected them more than they have the allotment of the pauper and his humble hut.

The iconographic tradition of the memento mori was, of course, of long standing, as was the poetic theme of tempus edax or "time, the eater." These notions were fitted onto the minor Enlightenment strain and could have a distinctly political cast, as when Sade opines 
that time is the leveller of "the fateful distinctions of this life." 131 Sade also used ruins as an occasion to critique religious systems and their false promises, his neo-Epicurean atheism showing through. Continuing his reflection on the ruins of empire on the Palatine Hill, he takes a bold stand and invites his reader's acquiescence: "More philosophical than those who fabricate these systems, which provide so little consolation, let us dare to believe that if new rewards do not await us, at least we do not have new pains to fear, and that the utter destruction of our being is the quittance that Nature owes us."

\section{New Views on Antiquity}

The artistic and structural remnants of the Roman Empire crowd the entirety of Sade's route. These remnants provide not only material for sweetly melancholic contemplation and nihilistic consolation, but they are also opportunities to uncover the past and to expatiate on ancient political and cultural history. The city of Rome, of course, and its environs is particularly rich in evidence of past glory. Our marquis visits the remains of the palace grounds and the Forum on the Capitoline Hill, the triumphal arches and imperially imported Egyptian obelisks, what was left of the Circus Maximus, the famous chariot racetrack, and of course, the Colosseum, the despoilment of which - for the construction of modern edifices - Sade bemoans. In the surrounding area, there are numerous other sights. Sade describes fragments he sees along the Appian Way as well as the remains of various country estates including the villa of Emperor Hadrian (76-138 CE), the Sabine estate of Horace (65-8 BCE), and the purported villa of Gaius Cilnius Maecenas (68-8 $\mathrm{BCE}$ ), the celebrated literary patron. He presents these with his by now well-thumbed copy of Chaupy's Découverte de la maison de campagne d'Horace (1767-1769) as ready reference. Campania likewise abounds with ruined villas, along with baths, engineering marvels such as the Grotta di Posillipo or Crypta Neapolitana, an ancient tunnel running under Posillipo Hill, near Naples, and entire cities, such as ancient Capua, with its amphitheatre rivalling Rome's in size. As he goes along, Sade proffers measurements and descriptions of archaeological remains that he asserts are more accurate than those provided by his rivals in the guidebook business, and he digs into ancient sources in search of proof about the capacities, purposes, and identities of various structures.

In preparing his manuscript, Sade made ample use of ancient historians, with Titus Livius, known simply as Livy (64 or $59 \mathrm{BCE}-2$ or $17 \mathrm{CE}$ ), being prominent for the early history of Rome and Gaius Suetonius Tranquillus, known as Suetonius (69-122 CE), from whom he took copious notes, for the Imperial era. Unfortunately, although Sade provides page references in two instances, which edition of Livy he used remains unknown to us. The main options in French translation were Les Décades de Tite-Live (The decades of Titus Livy) by the dramatic author and historiographer Pierre du Ryer (1606-1658), first published in 1653 and often reprinted, as well as the more recent Histoire Romaine de TiteLive (Roman history of Titus Livy) by the humanist and translator François Guérin (16811751), which first came out in 1738 , but neither appears to be the translation that Sade consulted and cited. There were more recent options for translations of Suetonius. These include Les douze Césars (The twelve Caesars) (1770) by the playwright, writer, and literary critic Jean-François de La Harpe (1739-1803), and Histoire des douze Césars, de Suétone (History of the twelve Caesars, by Suetonius) (1771) by the philosopher and historian Jean-Baptiste-Claude Deslisle de Sales (1751-1861) but published under the pseudonym Henri Ophellot de La Pause. We do know from internal references in his manuscript that 
Sade's Suetonius was the older standard by the prolific seventeenth-century translator and multilingual Sulpician priest, Jean Baudoin (1662-1698). Baudoin's Suétone Tranquille, De la vie des douze Césars (Suetonius Tranquillus, on the lives of the twelve Caesars) was originally published in 1611. These were hardly our author's only ancient sources. There are references in Sade's manuscript to a wide variety of historians and biographers, including Dionysius of Halicarnassus (c. 60 BCE-after 7 BCE), Plutarch (c. 46-c. 120 CE), Tacitus (56-c. $120 \mathrm{CE}$ ), and Cassius Dio, as well as to geographical and cultural writings from Seneca (c. 4 BCE-65 CE), Pliny the Elder, Pliny the Younger, Strabo (64 or 63 BCEc. $24 \mathrm{CE}$ ), and numerous others. Sade consulted broadly on early modern European political, Italian, and ecclesiastical history, and similarly made ample use of early modern sources on ancient Rome. Chief among the latter were Vertot's Histoire des révolutions arrivées dans le gouvernement de la république romaine and the twelve-volume work by Jean-Baptiste-Louis Crevier (1693-1765) entitled Histoire des empereurs romains, depuis Auguste jusqu'à Constantin (1749-1755) (History of the Roman emperors, from Augustus to Constantine) (1755-1761).

Sade's manuscript also cites a range of classical literary texts. Our marquis advises that if you are heading to the Kingdom of Naples, "Virgil is the traveller whom you have need to have in hand while traversing this happy countryside where he made his hero roam." Virgil still enjoyed more esteem than Homer in terms of epic poetry, the highest of literary genres, and tracking geographical references in The Aeneid is something in which Sade and other tourists indulged. Virgil's Eclogues and Georgics provided useful lenses through which to view the countryside and agricultural labour. The poet's supposed tomb in the Campanian countryside just outside of Naples was an important stop on the southern Italian grand tour. Here visitors might collect a leaf from the venerable bay tree that grew on the spot. Sade does treat the site as something of a tourist trap, however, and reasonably doubts the ancientness of the tree, which serves as a source of revenue for the local caretaker. ${ }^{132}$ The epistles, odes, and satires of Horace are intermittent points of reference, as are Martial's epigrams. If Marcus Valerius Martialis, known in English and French as simply Martial (born sometime between 38 and $41 \mathrm{CE}$, died sometime between 102 and 104), is mainly recalled for pungent insults and character evisceration, his short, witty observations are often inoffensive and contain tidbits of trivial yet interesting information. Where, for example, was the best olive oil made? Answer: Venafrum or present-day Venafro, as it turns out. Chaupy uses references from not just Horace, but also Cicero (106-43 BCE), Juvenal (50 CE-second century CE), Publius Papinius Statius (45-96 CE), as well as others to illuminate the archaeological record and to track down the identity of villas and other structures in the vicinity of Rome. Similarly, Sade mines literary authors for evidence and information about locations, place names, wines, regional specialties, and the like.

Sade employs both his ancient and modern sources in conjunction with his own firsthand examination of sites - another instance of empiricism of sorts - to formulate historical and archaeological conjectures that have vraisemblance, once again adapting this term from dramatic theory to his subject at hand. He puts forward explanations that seem to him truthlike (verisimilitudinous rather than assuredly true) because one cannot be certain of the past, and the evidence is not always good. I have often translated vraisemblable, the adjective corresponding to vraisemblance, as "probable" or "likely." In Rome, for example, Sade is discussing a temple at the time held to be dedicated to Minerva Medica because a statue of the goddess was found nearby. But Sade demurs, stating that a number of different 
statues of gods and godlike beings have been found in the vicinity, including Pomona, Hercules, Adonis, Venus, and Hadrian's "lovely favourite boy," Antinoüs. The more probable hypothesis is that the structure was $a$ pantheon, either a copy of or model for Agrippa's temple, otherwise known as the Pantheon in Rome. Or again, discussing the ruins of a temple near Lake Averno that some claim was dedicated to Juno and others to Apollo, Sade tells us that, lacking the discovery of an inscription that would decide the matter with certainty, he would opt for Pluto, since the nearby marsh was consecrated to the Lord of the Underworld, the entrance of which was purported to have been close by. This is the more likely hypothesis. Nevertheless, we must be ready to admit that when assigning probabilities is not possible, conjectures should not be made. Concerning the various country villas in the vicinity of Baiae that belonged to luminaries such as Caesar, Pompey, the consul Gaius Marius, the senator Gaius Calpurnius Piso, and others, Sade asserts that assigning correct ownership is impossible, and this in spite of Tacitus's precise indications. The upheaval in the interim has been too great. Sade maintains that he is "more frank" and "less interested perhaps" in passing off his "reveries as hypotheses [conjectures]" than those "writers of romances" - his fellow travel guide authors - who set them down as certainties. In cases such as this, Sade explains that he will simply state that he has "seen some ruins."

Some ancient sites stand out more than others on Sade's Italian journey. One of the archaeological highlights of Campania that had come to attention in the middle of the eighteenth century and was still growing in fame at the time Sade visited was the ancient seaside town of Paestum, with its three, largely intact Doric temple structures. The somewhat squat columns and simple capitals of these structures, solid and soberly majestic, were key to the Doric revival in later eighteenth-century architecture. First, however, resistance to the engrained notion that Greek architecture was frankly primitive and unattractive compared with Roman had to be overcome. ${ }^{133}$ Originally Poseidonia, the town was part of Magna Graecia, comprising ancient Greek settlements in southern Italy that included Sybaris, which became synonymous with voluptuary indulgence; Cumae, with its famous sibyl; Elea, home of the pre-Socratic philosophers Zeno and Parmenides; and Neapolis, that is, "new city," of which modern Naples is a corruption. Various claims were made in Sade's day about exactly who had rediscovered Paestum, located some fifty miles south of the capital, hardly hidden, but also off the well-trod path. In his Nouveaux Mémoires, ou Observations sur l'Italie et sur les Italiens, the travel writer Pierre-Jean Grosley reported that it was a Neapolitan art student who first heralded Paestum's splendour in 1755 - a story that circulated widely, at least in French. ${ }^{134}$ This was clearly incorrect or at least a gross exaggeration. In 1745, La Lucania, an account by Giuseppe Antonini (1683-1765) of the ancient Oscan and Hellenistic area of the southern peninsula, provided a long description of the site, referring copiously to ancient and modern sources. ${ }^{135}$ Antonini, for instance, notes that the German geographer Philipp Clüver (1580-1622), in his Italia Antiqua (Ancient Italy), published posthumously in 1624, claimed that the city was also known as Nettunia, after the god Neptune. Antonini rejects "con buona pace [with all due respect]" the opinion of "so great a man." "136 In 1750, moreover, Jacques-Germain Soufflot, who was then on tour with Madame de Pompadour's brother, visited and surveyed the site in the company of fellow French architect Gabriel Pierre Martin Dumont (1713?-1794). ${ }^{137}$ This visit would eventually lead to Dumont's illustrated, albeit inexact, account Suite de plans, coupes, profils, elevations ... de trois temples antiques dans le Bourgade de Poesto qui est la Ville Poestum de Pline (Series of site plans, cross sections, side views, elevations ... of three ancient temples in the village of Poesto, which is Pliny's town of Paestum) (1764). 
No matter who exactly was responsible for its fame, what is clear is that interest in Paestum took off in the mid-eighteenth century. Printed and illustrated accounts accumulated in the years prior to Sade's visit. These included The Ruins of Paestum, otherwise Posidonia, in Magna Graecia (1768) by Thomas Major (1720-1799) and The Ruins of Poestum, or Posidonia, a City of Magna Graecia in the Kingdom of Naples, Containing a Description and Views of the Remaining Antiquities (1767), published anonymously but attributed to physician John Berkenhout (1726-1791), which drew on Dumont, among others. Sade most likely used Dumont's similarly titled Les Ruines de Pcestum, autrement Posidonia, Ville de l'ancienne Grande Grèce, au Royaume de Naples (The ruins of Paestum otherwise Poseidonia, city of ancient Magna Graecia in the Kingdom of Naples) (1769), which presented itself as a free translation of Berkenhout's work and featured numerous engravings of both views and plans. The most celebrated illustrations of the site were to become Piranesi's engravings, made in the year or so following Sade's 1776 visit. At that point, Paestum was increasingly on the grand tourist's map, although, as Sade points out, still difficult and costly of access. Given the likelihood that not many of his readers would be able to visit in person, here Sade provides more detailed descriptions and measurements than usual. He also forwards a dubious hypothesis that this is where the "inventor of the Corinthian capital" worked, and thus "it would be quite possible that it was in Poseidonia that architecture began to take some steps forward [des progrès]." This hypothesis is based on an inscription at the site on which is found the name Callimachus. The same name belonged to a fifth-century BCE sculptor and architect whom Vitruvius claims as the inventor of the Corinthian order. ${ }^{138}$ As Laugier explains in his Essai sur l'architecture: "Everyone knows the story of the sculptor Callimachus. The first notion of the Corinthian capital came from his chance encounter with a vase around which an acanthus plant had carelessly raised its leaves and stems." 139 Why Sade considers the Callimachus at Paestum to be the same as the one who is thought to have worked primarily in Athens and, obviously, in Corinth, and to have developed the most ornate of the three classical orders is not evident. Aware that he was out of his depth, Sade notes in the margin: "Read up thoroughly on architecture before asserting this." What Sade's assertion nonetheless does reveal is an ongoing resistance to the simple grandeur of the Doric: the Corinthian order and increasing complexity is clearly deemed a sign of progress in the arts. For Sade, Paestum's simplicity may have been magnificent and beautiful in its way, but the structures were also but preliminary indications of the true architectural greatness to come (see Plate 6).

Sade visits three other sites in Campania that were very much eighteenth-century discoveries: the ancient towns of Herculaneum, Pompeii, and of lesser renown, Stabiae. All three had been buried in the eruption of Vesuvius in $79 \mathrm{CE}$. The date of the discovery of Herculaneum varies slightly depending on the source, but the early 1700 s is certain enough for the initial findings. One of the first accounts of the town was Lettres sur l'état actuel de la ville souterraine d'Herculée, et sur les causes de son ensevelissement sous les ruines du Vésuve (Letters on the current state of the underground city of Herculaneum, and on the causes of its burial beneath the ruins of Vesuvius) (1750) by Charles de Brosses (1709-1777). According to de Brosses, at the beginning of the century some villagers from the vicinity of Portici were digging a well and unearthed variously coloured marble. Then, in 1711, the prince of Elbeuf, who required "powdered marble for the production of stucco for a country house he was having built in Portici," ordered excavations at the same spot. ${ }^{140}$ At that point, "a temple decorated with columns and statues" was discovered. De Brosses reports that the latter were carried off and sent to Prince Eugene of 


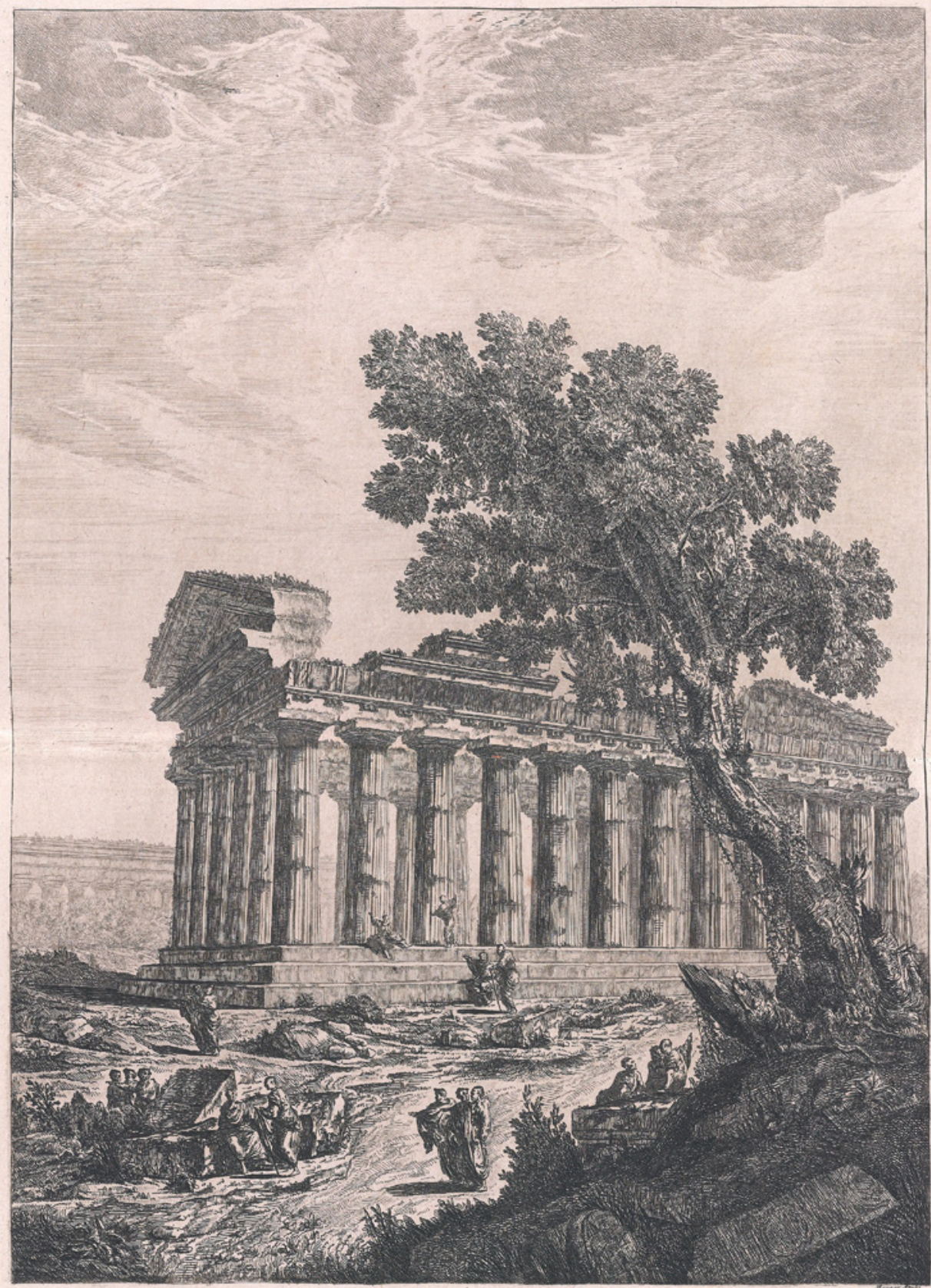

Viue perspective du plus petit des trois Temples antiques de Pastium.

Figure 0.5. Temple at Paestum, from Gabriel Pierre Martin Dumont, Les Ruines de Paestum (1769). 
Savoy. Emmanuel Maurice de Lorraine-Guise, duc d'Elbeuf, was lieutenant general in the cavalry of the Holy Roman Emperor Joseph I (1678-1711), and then resident in Naples. The excavations that he began, however, soon came to a halt, with d'Elbeuf returning to France. They began again in earnest and on a larger scale in 1738, and this time with royal impetus. The work was overseen by Roque Joaquín de Alcubierre (1702-1780), a Spanish military engineer in the employ of the young King Charles of Naples and Sicily (1716-1788), crowned in 1735 (he would abdicate in 1759 to become Charles III of Spain). Alcubierre also reconnoitred the vicinity for other buried sites, and excavations for what was discovered to be Pompeii began in 1748. Encouraged by the discoveries at Herculaneum, the sovereign ordered a systematic examination of the Pompeii site. The amphitheatre, theatre, and other parts of the city were unearthed, although work slowed. Excavations at Stabiae, which was discovered shortly after Pompeii in 1749, were barely pursued during the eighteenth century. Sade observes that when he visited Stabiae only some three or four houses had been uncovered. The work at Stabiae was abandoned in 1782, not long after Sade's visit, and the town would have to wait until the middle of the twentieth century to be discovered once again.

The Bourbon rulers were often subject to accusations of neglect, and Sade echoes common complaints about the pace and care of the excavations. If he found that the work at Stabiae was proceeding slowly, he deems the small size of the contingent working at Pompeii "appalling." He lays the blame on Ferdinand IV of Naples (1751-1825), Charles's son and successor, an "incurious prince," whose lack of a principal enlightened value curiosity - translates into a lack of financial commitment and care. Nevertheless, both the current monarch and his predecessor were protective of their properties. ${ }^{141}$ Maybe thanks to the memory of the duke of Elbeuf's earlier private enterprise, control over the Herculaneum site seems to have been particularly tight. The architect Jérôme Charles Bellicard (1726-1786) wrote the preface to the English edition of Observations upon the antiquities of the town of Herculaneum, discovered at the foot of Mount Vesuvius: with some reflections on the painting and sculpture of the ancients: and a short description of the antiquities in the neighbourhood of Naples (1754), which included descriptions by Charles-Nicolas Cochin of paintings and sculptures unearthed at the site. Bellicard informs us that while he would provide plans for the main buildings of the town, he would be unable to give dimensions, "for the inspectors of the works, and those who conducted the digging, had so severe orders on that subject, that they would never indulge me an opportunity." 142 Bellicard also explains that the illustrations of paintings that he provides from previously published material were "engraved after designs made from memory," although "they pretty accurately represent the composition of the subjects, and even the principal defects for which the originals are blamed." ${ }^{143}$ He includes some drawings by his own hand, likewise made from memory. Artists were evidently banned from working in situ. In 1755, King Charles set up a museum at his new palace in Portici, where objects excavated at Herculaneum and elsewhere in the region were gathered for restoration and viewing. Sade points out that when he visited the museum during the reign of young Ferdinand IV, who had turned twenty-five during Sade's stay in Naples (he had been crowned in 1759 at the age of eight and the regency, overseen by the powerful minister Bernardo Tanucci [1698-1783], had ended in 1767), visitors were tightly regulated and forbidden to take notes or make sketches. More than simply ensuring that objects were not expropriated, the Neapolitan rulers were interested in controlling the flow of information, including images, related to the excavations. Starting in 1757 and continuing until 
1792, the eight-volume, illustrated Le Antichità di Ercolano Esposte (The antiquities of Herculaneum revealed) was published. Commissioned by Charles, continued during his son's regency and afterwards, these volumes were overseen and penned by a scholarly committee and illustrated by multiple engravers. Given as royal gifts only, they were not easily consulted, although illicit versions arose soon enough. Notable in this regard is an English translation by the botanist Thomas Martyn (1735-1825) and the poet, essayist, travel writer and divine John Lettice (1737-1832) of an earlier catalogue of the findings, accompanied by illustrations after the Antichità di Erolano Esposte and published in London in 1773 under the title The Antiquities of Herculaneum. ${ }^{144}$ The images were thus just starting to circulate more widely at the time of Sade's visit in 1776. Indeed, a French translation and presentation would not appear until 1780, as Les Antiquités d'Herculanum avec leurs explications en françois (The antiquities of Herculaneum with explanations thereof in French), published in Paris, with engravings by François-Anne David (17411824) and explanatory text by the poet, philosopher, and unabashed atheist Pierre Sylvain Maréchal (1750-1803).

One revelation of the Campanian excavations was ancient painting. The rich trove of frescoes, along with bronzes, was an important focus of the Antichità di Ercolano Esposte, with five of its eight volumes dedicated entirely to this subject. These discoveries would become another key shaper of the classical revival; their initial reception, however, was far from ecstatic. Cochin, for example, did not hold the paintings of Herculaneum in high regard, and finds they are not examples of the best Hellenistic artists. Typically, Sade himself judges a lack of accuracy in the paintings he saw at Pompeii and in the royal museum. A painting of a satyr accosting a surprised young woman with a kiss "is not without expressiveness, although mediocrely drawn." Concerning a satyr who wishes to play with a boy, Sade is impressed with the power of expression of the former and the ingenuousness of the latter, adding that you can see "quite well that the one desires that which he knows will give him much pleasure, and that the other has not yet learned to dread that which he does not know will cause him much pain." I have already noted Sade's similar take on the painting of Achilles and his mentor Chiron discovered at Herculaneum. Sodomy, it seems, is never far from Sade's mind. Along with expression, Sade appreciates the remarkably intact vividness of the paintings unearthed at Stabiae, which struck him as even more vibrant than those at Pompeii. Vividness or vibrancy was an important quality in judging coloration. Though perhaps more important still were the subjects depicted, which included examples bawdy and at times frankly obscene - objects that would appeal to the curious libertine mind. The standout instance for Sade is the statue of a satyr and a goat captured in flagrante delicto unearthed at Pompeii and removed to the Portici residence of the realm's royal sculptor Joseph Canart (1713-1791) (see Plate 7). This was the most secret and singular piece of the entire, extensive collection. For Sade the lurid subject matter does not appear to detract from the excellence of the work, which suffers none of the faults of the ancient paintings:

It is a marble group about a foot and a half high that depicts a satyr enjoying a she-goat. It would be hard to put more soul and expressiveness than the artist has done, as much in all the movements and muscles of the satyr as in those of the she-goat. Her tongue on the edge of her lips expresses all the pleasure she feels, and the lively manner that the satyr holds her by her little beard contributes not a little to the heat. All is in action in this lovely piece, all is on fire; the most exact purity of style characterizes it. 
Sade comments that, thanks to "the moral austerity of Marquis Tanucci," access to this statue is severely restricted, requiring permission that the king grudgingly and but rarely gives. Not everyone, he states, will be able to judge the work, and we may legitimately wonder if Sade provided a first-hand account. Johann Joachim Winckelmann (1717-1768) was Pope Clement XIII's prefect of antiquities and a key figure in the elevation of the assessment of Greek classical art and sculpture, in particular. Concerning his visit in 1762 to Herculaneum and the museum at Portici, Winckelmann reports that, while granted access by a compliant guard to some restricted items in the collection, he was unable to see this "obscene object [unzüchtige Figur]," reputed to be "quite beautiful." He knew that "written permission in the king's own hand" would be required and explains that he did not wish to be the first to request an exception from this rule. ${ }^{145}$ As for "that handful of Englishmen who brag" that they have seen it, Winckelmann contends that they lie. ${ }^{146}$ Perhaps Sade was trying to impress as well, or maybe access to the sculpture had become somewhat laxer in the intervening years.

Beyond artworks, what the excavations provided was the most complete and preserved material culture of the ancient Roman lifeworld - or at least a particular stratum of this world. Certainly, libertine aspects of this world could be posited, but more than this what Sade and other observers saw was a society and culture that on the surface appeared to be radically other than Christian modernity, including - or most especially - with regard to religion and sexuality. As Sade informs, regarding some of the contents of the museum, these included various sacrificial implements, such as "vases, patens, an altar, bowls, tripods, of which one among others was used for sacrifices to Priapus." Sade adds that "three lovely figures of this god, characterized in a singular manner, support it." That singular manner is ithyphallic. Sade argues that the number and variety of priapic figures found in another room confirm the importance of this deity at Herculaneum. One of them even takes the form of a terracotta drinking vessel. Sade's sexually enlightened aside at this point is that young people today are frightened of Priapus's image, whereas once it was familiar and respected from infancy on. Our marquis was hardly alone in his fascination with the priapic figures unearthed in the vicinity of Naples. At this moment, something like a full-fledged comparative anthropology was beginning to unfold, and these apparent oddities, which turned out to be universally prevalent, were a key topic of examination. D'Hancarville's Recherches sur l'origine, l'esprit, et les progrès des arts de la Grèce; sur leur connexion avec les arts et la religion des plus anciens peuples connus; sur les monumens antiques de l'Inde, de la Perse, du reste de l'Asie, de l'Europe et d'Égypte (Research on the origin, spirit, and progress of the arts of Greece; on their connection with the arts and religion of the most ancient known peoples; on the ancient monuments of India, Persia, the rest of Asia, of Europe, and of Egypt) (1785), for example, sought out commonalities and connections between phallic worship and representations in Greece, Hellenistic Italy, Persia, and India. The museum at Portici provided important evidence. In 1786, the classical scholar and archaeologist Richard Payne Knight (1751-1824), who toured extensively in Italy, published his controversial account of pagan phallic idolatry, A Discourse on the Worship of Priapus, which drew explicitly on d'Hancarville's earlier studies. Against a literalist interpretation of these ancient sects, both men argue for symbolism in Greek and Egyptian worship. In Payne's words, "the organ of generation" figured forth the "great characteristic attribute," that is, power, of the creator. ${ }^{147}$ Further, Payne explains, ancient phallic rites were not essentially "ludicrous or licentious," but rather these "matters of very curious enquiry" were ultimately grounded in reason and reality: "nothing can be more 


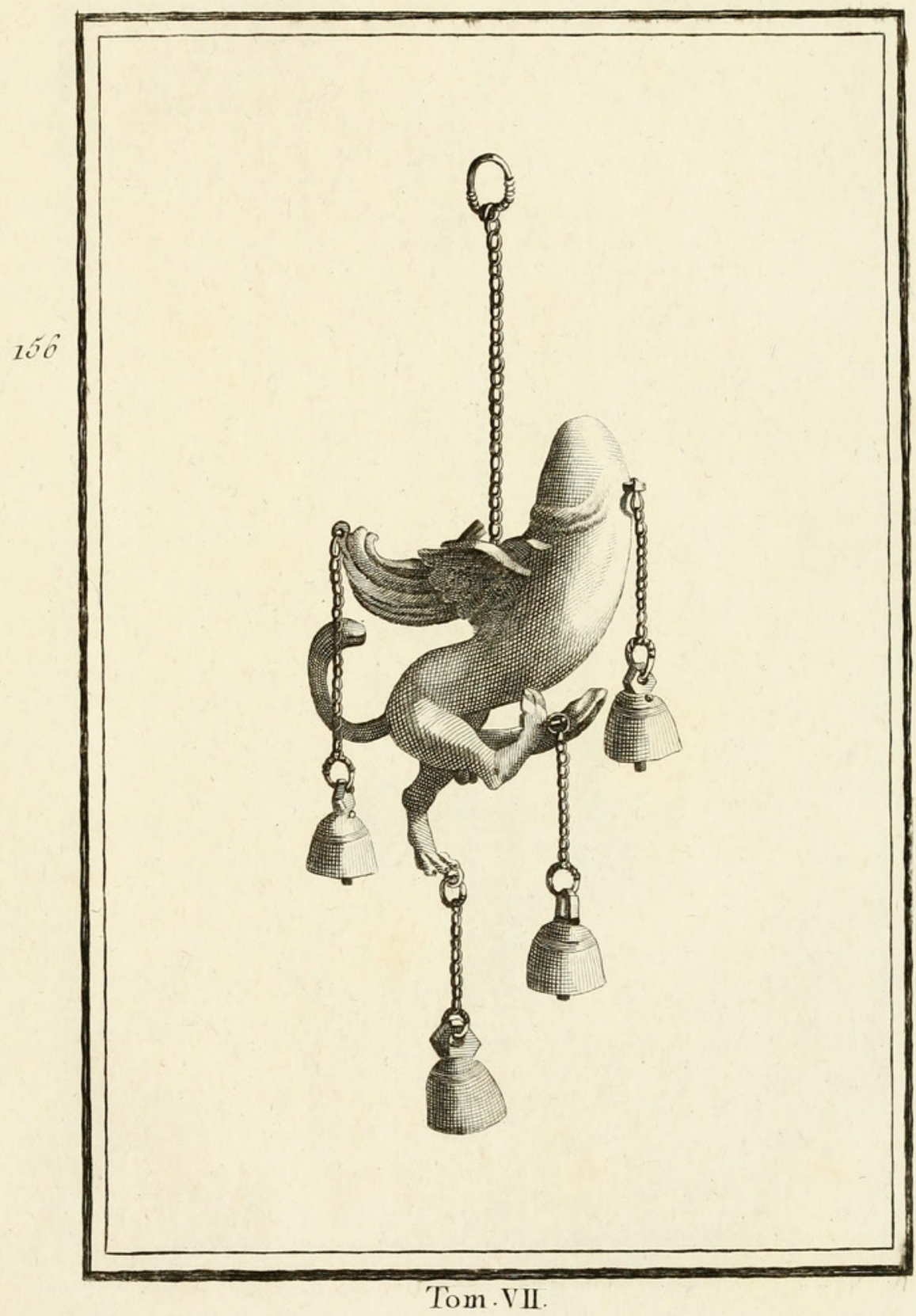

Figure 0.6. Winged priapic amulet, engraved by François-Anne David, from Pierre Sylvain Maréchal, Antiquités d'Herculanum (1780). 
monstrous and indecent, if considered in its plain and obvious meaning, or as a part of the Christian worship," than this rite, but in it will be found "a very natural symbol of a very natural and philosophical system of religions, if considered according to its original use and intention." ${ }^{148}$ Neither Payne's nor d'Hancarville's works were sources for Sade. Their publication post-dated his visit to Naples by a decade. They are, however, useful examples of anthropological and historical interest in pagan practices and, below the surface and sometimes more openly, their ongoing presence in Christian practices and beliefs - something that intrigued Sade, too. Indeed, Payne's work was prefaced by a 1781 letter from Sir William Hamilton on the persistence of these pagan customs and their integration into Christian ritual in modern Italy, with particular reference to celebrations held in the town of Isernia, near Naples, that include wax ex-votos of male sexual organs. It also contained a letter from an anonymous Italian correspondent on the same. Such rituals confirmed the notion that Christianity had not so much exiled pagan idolatry as syncretically absorbed it. In far-flung locales like southern Italy, such absorption was partial at best.

\section{Inventing Sadism}

\section{The Libertine Renaissance}

In rejecting the notion that the re-establishment of the arts and sciences had led to the purification of mores, Rousseau states that ancient Rome, "founded by a shepherd and made famous by fieldworkers," had already begun to degenerate by the time of the Republicanera poet Quintus Ennius (239-169 BCE) and the playwright Publius Terentius Afer, better known in English simply as Terence (185-159 BCE). With the empire, literature and society would both take a turn for the worse: "But after the likes of Ovid [43 BCE-17/18 $\mathrm{CE}$ ], Catullus [84-c. $54 \mathrm{BCE}$, Martial, and that crowd of obscene writers whose names alone offend modesty, Rome, formerly the temple of virtue, became a theater of crime, the disgrace of nations, and the plaything of barbarians." 149 Rousseau's comments confirm that what the Renaissance rediscovered was a rich and varied classical tradition. This tradition included epics, odes, and pastorals, but also the erotic and frankly obscene. The printing press in conjunction with translation into vernacular languages was simultaneously making such material increasingly available. Michel de Marolles (1600-1681) was a collector of prints, salon participant, the abbot of Villeloin, and a prolific translator. Marolles rendered into French many classical works, including the following: Statius's esteemed epic The Thebiad; the comedies of Plautus (c. 254-184 BCE); the materialist and Epicurean didactic poem De Rerum Natura (On the Nature of Things) by Titus Lucretius Carus, or simply Lucretius (99-c. 55 BCE); and much more, including numerous writings by Ovid, among them the bawdy Ars amatoria (Art of Love), as well as Catullus's boldly lascivious lyrics, and Martial's witty and often licentious epigrams. These were precisely the authors and sorts of writings that Rousseau, perhaps disingenuously, disparaged.

Although an abbot, Marolles clearly did not shy away from texts that might be considered indecorous and even morally dangerous. Nevertheless, he chose not to put his name on his translation of Martial, which appeared with royal imprimatur in 1655 in a bilingual edition as Toutes les Épigrammes de Martial en Latin et en François (All of Martial's epigrams in Latin and in French) and included a biography of the author and copious annotations. In his prefatory remarks, he notes that the majority of Martial's epigrams are not obscene. For those that are, Marolles explains that he has "either improved the expression 
thereof, by lending them quite often other conceptions than those present in the original text" or "suppressed them entirely." 150 The Latin, however, he left intact as "outside of my jurisdiction." 151 It may be helpful to consider briefly what sort of material the translator excised, what an erudite reader would have accessed, and what a reader of French alone would have missed. Marolles declared the first truly reprehensible rhetorically and morally dubious jibe that the reader would encounter in Martial's works to be epigram 28 of book 2. In Latin, followed by modern English translation, it reads:

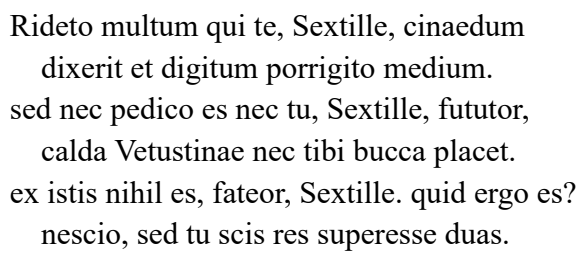

(Laugh heartily at whoever calls you a cinaedus, Sextillus, and show him your middle finger. And you are not one to fuck either asses or cunts, Sextillus, nor do the warm cheeks of Vetustina give you pleasure. I admit it, Sextillus: you are none of these. So what, then, are you? I don't know, but you know that two things are left.) $)^{152}$

The Latin text is given in Marolle's edition in toto. His translation is truncated thus:

Have a good laugh at whoever says that you prostitute yourself, Sextillus, and show him your middle finger. ${ }^{153}$

An accompanying note curtly explains that this epigram is "unbearable," that it "cannot be translated," and merely clarifies that "it was an insult to raise the middle finger at someone." 154 Some things, at least, do not change. Marolles's assertion of untranslatability evidently intends the epigram's moral ineffability, but there is also a cultural and linguistic problem. In particular, both English and French lack precise equivalents for a Latin sexual vocabulary that insinuates Roman concerns about male passivity. Cinaedus, an insult, was used for "an effeminate man who most likely, though not necessarily always, played the receptive role in anal intercourse." 155 The term derived from Greek, and the most common contemporary translation appears to be "queen," although "bottom" would be another option. These concerns about passivity explain what amounts to the epigram's punchline. We do not know the identity of Vetustina, although her name suggests old age; the epigram clearly implies that taking pleasure from her would only be in the form of fellatio. As for Sextillus - a diminutive form of the name Sextus - only two options remain: he is either a fellator, a man who performs oral sex on other men, or a cunnilingus, a man who does the same on women. Like cinaedus, both would be degrading sexual identities from the Roman perspective.

A thorough understanding of Latin and of Roman mores was required to grasp the meaning and feel the impact of writers such as Martial. And while we should not underestimate what erudite minds in the early modern era did comprehend, bear in mind that Sade was not a classical scholar. He was a well-read amateur who clearly had some Latin but whose knowledge came by and large from translations, some of which were more accurate and complete than others. If his use of classical writers in the Italian manuscript was primarily 
confined to clarifying and appreciating historical and archaeological sites and less interested in licence - why would it be, given the nature of his project? - his readings nonetheless added to a storehouse of material that he would activate in his libertine writing career. Ancient literature and practices also provided him with cultural evidence for his moral relativism. For example, Sade will cite from an epigram of Martial's in his Juliette in justification of male-male sodomy: "A woman acts in vain - in vain she turns over / She will always be a woman." "156 Along with Martial, this classical storehouse included Juvenal's excoriating and often lewd satires and Petronius's depiction of obscene decadence in the age of the Roman emperor Nero (37-68 CE) in the Satyricon (both are cited in the Italian manuscript; both were also translated by Marolles, although there were other options by Sade's day). Indeed, one simply cannot understand Sade's later writings without an appreciation of the large dose of satire, broadly speaking, that informs them. His travels in Italy catalyzed, if they did not necessarily give rise to, Sade's interest in the genre and style, from the gently corrective Horace to the lacerating Juvenal, not to mention their lesserknown precursor, the Roman poet and satirist Persius (34-62 CE). Sade's Italian research also informed him about ancient relations to satire: Fescennine Verses, salty dialogic banter initially associated with weddings; and Atellanae, farcical and often lewd comedies. Both became sufficiently licentious, anti-authoritarian, and sacrilegious that Roman law eventually intervened. Satire and its relations provided content and form for Sade's libertine writings. Still, his largest cache of classical material came from historians, among them Livy, Tacitus, Cassio Dio, Suetonius, and others. Sade would subsequently borrow from them: referring to, refashioning, and updating some of the more outrageous episodes of Antiquity.

When the Marquis de Sade began to pen his licentious writings in earnest in the Bastille, some ten years after his flight to Italy in the summer of 1775 , libertine writing was a well-established, if clandestine, genre in France. Such works, themselves informed by the rediscovery of the classical tradition in its variety, were other models for him. Already considered classics in the genre in the eighteenth century were the explicit dialogues L'École des filles (The school for girls) (1655) by an unknown author or authors, Chorier's Aloisiae Sigaeae and its French translation L'Académie des dames, and the fictitious abbé du Prat's Vénus dans le cloître, detailing the sexual education of nuns. ${ }^{157}$ Sade carried the pedagogical references in the titles and content of these works in the full appellation of his first licentious outpouring: Les 120 journées de Sodome, ou L'École du libertinage (The 120 Days of Sodom, or the School of Libertinage). He likewise followed their heuristic, dialogic format in his subsequent work La Philosophie dans le boudoir (1795) (Philosophy in the Bedroom), which recounts the initiation and training of a young aristocratic woman - the aptly named Eugénie, that is, "well-born" or, stretching etymology, "born for pleasure" into radical libertine ways. ${ }^{158}$ It is the last major dialogue in the libertine corpus. All these works looked to an Italian predecessor in the whores' dialogues of Pietro Aretino, I Ragionamenti. The inventory of Sade's library in 1776 reveals an edition in the original Italian of this work, presumably purchased en route, under the title Capricciosi et piacevoli ragionamenti di M. Pietro Aretino (Fantastical and pleasant arguments of Mr Pietro Aretino), which appears to have been printed in Amsterdam in 1660. (The place of publication with clandestine works is a notoriously slippery affair, and many licentious publications provide humorously misleading information such as Cythera, the birthplace of Venus. ${ }^{159}$ For Aretino's dialogues, there was classical precedent in the comic conversations of courtesans that Lucian had depicted in the second century. ${ }^{160}$ In his dedication, Aretino explicitly mentions "the salacious works" of Ovid, Juvenal, and Martial, thus clear inspirations as well. ${ }^{161}$ 
Sade, in his Italian manuscript, briefly indicates that he also knew of - if he had certainly not seen an illustrated version - Aretino's earlier Sonetti lussuriosi and their arch commentary on sixteen modi or sexual postures by the painter Giulio Romano (c. 1499-1546) and engraved by Marcantonio Raimondi (c. 1470/82-c. 1534). This was a rare work, indeed, with most of the originals destroyed, along with the engraved printing plates, by order of the pope (Clement VII) himself, in 1527. The only known extant version today is a single pirated copy with woodcut prints, and it is incomplete. ${ }^{162}$ In this case, the author and artists drew on a rich pagan iconography and literary tradition. Ovid, for example, in his Ars amatoria had described some of the "thousand modes of love [mille modi veneris]" and how they should be decorously adapted to body type and situation. ${ }^{163}$ Sade knew from the excavations at Herculaneum and Pompeii, which disclosed in detail aspects of sybaritic paganism, that in Antiquity these traditions ran deep. He explains that the museum in Portici, for example, had on display "bacchanalias" depicting "postures as surprising as they are peculiar and evidence of a truly disordered imagination." It was Aretino's name, however, that would become indissolubly associated in libertinism with the enumeration and description of sexual positions. Later libertines sometimes forgot the deep classical roots of their philosophy, lifestyle, and know-how. Sade, for one, remained acutely aware of the storehouse of Antiquity and how its varied contents had informed a sometimes scurrilous literary modernity.

\section{Justifications}

In truth, Aretino's lewd sonnets are actually much more humorous and satirical than erotic in tenor and content. The notion that Aretino's elaboration of $i$ modi was pedagogical in intent probably has more to do with the author's descriptions and characterizations in his dialogues, where a convent newcomer receives for her edification a book "crammed with pictures of people amusing themselves in the modes and postures performed by the learned nuns" of this establishment. ${ }^{164}$ Yet here, too, the author's aim was not amatory instruction but jocular critique. Social satire was, in fact, a major mode of the literary re-establishment, of which Aretino's prose works provide one of the finest and sharpest examples. Satire would remain, moreover, a significant aspect of libertine writing in the eighteenth century and was rhetorically suited to the wave of licentious works in the 1740s and afterwards that entwined licence and philosophie in the partisan sense. Clandestine writings with sexual content became vehicles for atheism and materialism hedonically expressed. If humans were sensible machines, as La Mettrie had contended in his neo-Epicurean L'homme machine (1747), then what better proof of this hypothesis than not only depicting these mechanisms in play but inducing involuntary responses in readers through these very depictions? ${ }^{165}$ Sade folded the tradition of philosophical critique and often snide cynicism copiously into his later writings, along with the libertine-cum-philosophical gambit of demonstrating the force of bodily materialism through the elicitation of response. Such philosophical fare is prominent throughout Sade's mature works, where villainous and usually murderous lechers never fail to hold forth on the vacuity of morality and the selfevident value of pleasure, no matter the sort. Thus, in La Philosophie dans le boudoir, learned digressions on atheism and sensibility preface practical lessons in debauchery. Or is debauchery, in fact, a digression from philosophy? This mode of philosophizing was something that Sade borrowed from Voltaire, d'Holbach, and other philosophes, and in his Italian project he began to explore and sharpen his own rhetorical practices in this regard. 
There are numerous examples in the text. One choice instance has Sade commenting on a church, the extensive bureaucratic hierarchy of which enjoys significant wealth. Such riches have never led these clerics to succour the suffering populace in times of crisis, a fact that is hardly astonishing if you know what lies in a "priest's heart" - like Pandora's box, a repository of evils. As for the existence of priestly virtues, Sade affirms that these are incompatible with "serving a God whose essence is whim and freakery." After all, "by what right would the servants be better than the master?" Yet perhaps there is a glimmer of hope for the future: "When will the universe, in disabusing itself of the idol, annihilate those who serve it? And when will philosophy triumphant on the altars of superstition enjoy in full the worship of humanity and owed only to its beneficent torch?" All that is required for insertion into Sade's later writings is a rejection of the standard assumption that when the corrupting powers of priestcraft and credulity are removed, humanity will be revealed as beneficent and philosophy's triumph benign. Similarly, the insertion of relatively subtle if surprisingly frank apologias in the Italian manuscript for - to take the most obvious case sodomy presage the robust defences of all manner of perversities in Sade's later writings. These will include activities that most people would find morally or viscerally repugnant: torture, murder, and the consumption of all manner of bodily ejecta. Such so-called errors are but idiosyncratic tastes. They are no less natural or permissible for being off-putting to most and certainly not wicked. Evil is neither a reasonable nor a natural category.

It was not just philosophical critique that entered Sade's later works through his Italian journey. The personae of the policymaker or so-called projector and the virtuoso are firmly woven into his licentious writings. The former is most obvious in the case of the pamphlet inserted into La Philosophie dans le boudoir, which includes a mock project for the reform of laws and governance in France. This pamphlet pours derision on sincere politico-economic concerns about the size and health of the population. Among other items, it recommends the legalization and complete deregulation of prostitution and this regardless of gender or age. Sade's earlier presentation of the horrors of the Neapolitan sex trade were now given his approbation, although perhaps only in indelicate jest. ${ }^{166}$ Sade would also maintain a strong interest in anatomy and experiment. The anatomical models that were being built with the oversight of the surgeon Giuseppe Galletti by the waxwork artists and sculptors Giuseppe Ferrini and Clemente Susini, with their lifelike representation of the stages of pregnancy, intrigued Sade at the time of his visit to Florence. In both Justine and at greater length in La Nouvelle Justine, he would put anatomists and surgeons into action with two characters, named Rodin and Rombeau, who for a time hold the antiheroine captive. Among other atrocities, these two contrive to undertake the vivisection of Rombeau's daughter in order to better understand the organs and nature of generation. Rombeau exhorts his companion to consider how such an operation "will be useful for anatomy," which will never "reach its final degree of perfection, until the examination of the vessels [of reproduction] is undertaken on a child fourteen or fifteen years old, having died a cruel death." 167 Rodin agrees, and notes that historically the tribe of Hippocrates has never hesitated to undertake such experiments. He adds, alluding to paintings that Sade had seen during his Italian tour, "All artists have thought the same: when Michelangelo wanted to depict Christ naturally, did he worry his conscience about crucifying a young man and copying him in anguish? Guido's sublime 'Magdalene in tears' was taken from a lovely girl whom the students of this great man had whipped atrociously; everyone knows that she died from this." 168

Sade first invoked these justifications in his Italian manuscript. Contemplating a painting attributed to Michelangelo of the crucified Christ in the Charterhouse at Naples, "which 
we are told was veritably drawn from life," he remarks that such an act would be "a quite simple matter in the eyes of an artist philosopher." Sade goes on to argue that a careful inspection of the painting reveals that the model must have been "bound and tied," but as to whether the artist "truly crucified him in order to grasp, from nature itself, those precious moments of truth that one can only find therein," our author has his doubts. The expression captured in the painting does not lend credence to those who would claim that the crucifixion had been actually carried out. ${ }^{169}$ Sade opines that maybe Michelangelo would have done better to have gone to such an extreme. Sadly, the artist "had his prejudices, and prejudice was and always will be the reef of true talent." In a longer note on this painting in the working notes for his book project, Sade clarifies that he would not condone "such a violent and intolerable excess for an art as frivolous as painting," but that what could make a crime of the sort acceptable "would be the art of surgery":

an art necessary to human preservation and for the perfection of which an experiment done in a living state would perhaps shed light on a huge number of doubts and conjectures, which never will be on account of the foolish and ridiculous timidity that prevents sacrificing a villain whose life is good for nothing, to learn perhaps how to preserve those of a hundred thousand subjects useful to the State.

We have not reached the point where "philosophy" is sufficiently developed that we would see this moral calculus whereby the worthless and "obscure" are justifiably annihilated for the sake of the many. But if, in his Italian manuscript, Sade apparently recants concerning the ultimate sacrifice to art, he nevertheless would allow artists considerable moral leeway. He remarks of Titian's Venus in Florence that the model "served him in more than one way": "These are the sorts of physical furniture that an artist and a man of letters cannot easily do without." Paraphrasing Lucretius, he remarks that with these sorts of outlets at one's disposal, "Nature is satisfied and one's head is not unsettled." 170 We have already seen that Sade cleaved to the same Epicurean-cum-utilitarian exceptionalism with regard to Jerôme Duquesnoy's pederastic curiosity.

The topos of philosophically justifiable murder remained a favourite of Sade's throughout his career. In Juliette, he would even demonstrate that he was not ungrateful to his erstwhile companion and correspondent Giuseppe Iberti by casting him briefly as a character "the prettiest, wittiest, most lovable doctor in Rome" - who maintains that there is nothing criminal about using the inmates of almshouses for experiments and that, on the contrary, it is a boon to society. ${ }^{171}$ Sade added a footnote, using the informal $t u$ form of address:

Allow me to render you this homage, charming friend, whom I will never forget; you are the only one whose name I have decided not to disguise in these memoirs. The role of philosopher that I have you play here, suits you too well for you not to pardon me for pointing you out to the entire universe. ${ }^{172}$

It is hard to imagine that Iberti appreciated the compliment.

Perhaps most intriguing of all, however, is that in the fictional episode of the curious surgeons and anatomists Rodin and Rombeau, Sade not only cast his characters as virtuosi, but he also incorporated his own self-presentation as an amateur scientist. This was a role that Sade performed in the pages of the Italian manuscript, now combined with his own depiction in the scurrilous press as a human vivisector - or vivo-disséqueur in Rétif de la Bretonne's characterization of Sade - in the aftermath of the affaire d'Arcueil and based 
on the purported details of his treatment of Rose Keller. ${ }^{173}$ As for that hint of sympathy for suffering animals that Sade expressed in his account of the Grotta del Cane, where he attempted to balance his persona as scientifically detached virtuoso with that of sentimental observer, this he would in his licentious writings both elaborate and undermine. To a large extent, notions of nervous sensibility arose out of animal experimentation before they were joined to sentimental discourse and turned around to critique scientists, especially amateur experimenters. Sade gave this yet another twist, where the sensible response of a spectator to another's pain is stripped of the moral quality of pity and converted into erotic charge. In a grand, overarching way, one could say that what Sade's licentious works represent are experiments in nervous sensitivity and what they do is test such response in his readers. They are a satirical extension - both mischievous and malicious - of Samuel Richardson's literary techniques and a flagitious twisting of philosophical libertinism's elicitation of sexual excitement as proof of its materialist thesis. ${ }^{174}$

\section{Violence}

This takes us to the heart of Sade's peculiar literary libertinism or the historical particularity of sadism. In terms of sexual explicitness, Sade's mature works are more or less equivalent to novels of the radical phase of libertine expression in France. This period stretches from roughly the 1780 s through the French Revolution. It includes works, published anonymously, by André-Robert Andréa de Nerciat (1739-1800) and Honoré-Gabriel Riqueti de Mirabeau (1749-1791), along with a host of other writers whose identities remain unknown. Mirabeau was in many respects Sade's doppelganger. He was an aristocrat from Provence, the son of Victor Riqueti de Mirabeau, famed for his work on population. Mirabeau fils would pursue a libertine lifestyle, to the chagrin of his family and others affected by his wayward comportment. Like Sade, he was also prone to occasional violence. In 1775, he had an affair with a young married aristocrat named Sophie de Monnier, and the two fled to the Netherlands. They were tried in absentia, and Mirabeau was sentenced to death for seduction and kidnapping. Eventually captured, Sophie was condemned to a convent and Mirabeau imprisoned in the Château de Vincennes by lettre de cachet in 1777, at the same time as Sade was there. The two men despised one another. Before becoming one of the key figures and rhetors of the Revolution - he died in 1791 at the age of forty-two, in the midst of the epochal uprising - Mirabeau pursued a lurid libertine publication career. Like Sade's, his licentious writings include descriptions and robust defences of sodomy. Unlike Sade's, they are not violent nor do they obsessively incorporate excreta into the carousals. In Juliette, Sade would even have his eponymous heroine complain of one key radical libertine work, Le Rideau levé, ou L'Éducation de Laure (The raised curtain, or the education of Laura) (1786) - traditionally attributed to Mirabeau, although Sade gives no indication that he thought the anonymously published work was penned by his nemesis that, while the novel hinted at "uxoricide" and incest and was "full of imagination," it was an opportunity manqué. In particular, it failed to "put into action the cruel tastes of which it gave but a notion in the preface." 175 Juliette adds that "tremblers" exasperate her, and that she would prefer that they would write nothing at all than provide us with "half-notions."176 Sade was clearly no such trembler. Although his writings are doubtless part of the radical phase of libertinism, their particularity stems from Sade's linkage of sexual graphicness and exaggeration to the bodily grotesque and horrific cruelty. This begins with the grisly and wilfully repulsive Les 120 journées de Sodome and does not abate. If flagellation had 
long held a place in libertine writing and practice, violent encounters could be part of libertine plotlines, and scatology never entirely absent, Sade was venturing into new territory for libertinism and forging that amalgam that I have described as sadism proper. The biography of the Marquis de Sade suggests that an irascible and at times violent temperament pre-existed his libertine writing output. Young Sade does not, however, particularly stand out on the roll call of tempestuous, imperious, and cruel aristocrats. Further, while his mature writings may have been unique in the combination, Sade is no sudden "block of abyss" - as some of his philosophical apologists would have it - nor are his writings so unique that we must approach them as diabolical marvels, existentialist gambits, or surrealist paradigms. ${ }^{177}$ It is here that the passage through Italy is crucial, for this journey provided Sade the writer with numerous cases of violence and often sexualized violence that could and did inform his libertine literary oeuvre.

Classical mythology and literature overflows with grotesque brutalities such as the flaying of Marsyas. As for sexual violence, Ovid's Metamorphoses, which Sade uses as a guide for ancient iconography and modern reinterpretations, has erotic encounter, pursuit, and rape as a running thread. Ancient art drew unstintingly from these wells, and Sade encountered numerous examples on his travels. He admires as "singularly expressive," for example, an ancient, albeit restored, statue in the Villa Ludovisi in Rome of Pan attempting to rape a nymph. Modern artists took inspiration from the same sources, and Sade similarly praises the expressiveness of Bernini's Rape of Proserpina, the statue of Pluto carrying off Proserpina, in that same collection. Not that Christian history and iconography were lacking in this regard. Evocative biblical instances of violence that are mentioned in the Italian manuscript include Jael driving a nail into Sisera's head and the decapitations of Holofernes and John the Baptist (Caravaggio's "lovely horror"). He critically judges the visceral cruelties of the Passion and the Crucifixion, and he notes plenty of other examples of gory persecution. Like Marsyas, Saint Bartholomew was flayed, his horrific demise represented in painting and sculpture. Indeed, depictions of martyrdom were everywhere to be found on Sade's route through Italy, including the alarming instances in the Santo Stefano Rotondo in Rome, "one of the most frightful collections of horrors that could possibly be gathered." Sade singles out from this collection "a young female saint whose executioners are tearing off her breast." Such are the sorts of scenes that our author will recall and reinvent with glee in his later works. In La Nouvelle Justine, for example, Nero is said to have "voluptuously shredded [...] the pretty nipples of Saint Cecilia" and "the lovely buttocks of sister Agatha, who had, both of them, the idiocy of believing in Christ."178 Sade's own characters will commit acts much the same.

Italian history over the long run is replete with not only examples of mythical and artistically represented violence, but real examples, too. Abbé Richard lets us know that the traveller to Italy will find in its ruins unequivocal proof that here knowledge and know-how flourished. At the same time, he declares, "how many monuments of ambition, of jealousy, of intrigue and perfidy, how many bloody scenes, truly dishonouring humanity, do not these fragments of antiquity recall [...]?" "179 Sade in his manuscript guide to Italy likewise contemplates ancient magnificence alongside the ancient cruelties of warfare, criminal justice, and, of course, corruption and decadence. The ambiguous heritage of Rome would become an unambiguous source for him in his later writings. Most obvious was the ancient appreciation for the gladiatorial arena. Sade finds a reflection of this taste in modern Italy in the public execution of criminals, noting with philosophically progressive disdain that this is "still one of the most popular spectacles in Rome, even among women." Sade does 
not openly embrace what had taken place in the Colosseum, but he does point out to us the vast "difference between our spectacles" and those of Rome: the "bloody scenes" may have been barbarous, "but at least such games did not enervate courage as ours do, where the mere pantomime of an actor killing himself makes us cry." Roman mores allowed them "to witness death calmly," and while Sade grants his implied reader's insistence that they were "ferocious," "they were great, and we, we are, I agree, very human - but very small." This contrast between the tender humanity of early modern Europeans, on the one hand, and the greatness of the ancients, on the other, was a refrain in much otherwise sentimentally inclined moral philosophy. Such greatness included not only the stomach to witness suffering without compassion, but often a penchant for outright cruelty. Diderot in his art criticism, where he otherwise lionized the lachrymose Greuze, would write that he hates "all those little base acts that only reveal an abject soul," but that he does not despise "great crimes," for they make for "beautiful paintings and beautiful tragedies." He adds, "Great and sublime actions and great crimes carry the same imprint of energy." 180 Diderot mentions Marcus Aurelius (121-180 CE) as an example of virtuous heroism and Cesare Borgia (1475-1507) as an epigone of the villainous variety. Sade likewise will find plenty of examples of violence not only in ancient Rome, but also in more recent Italian history.

Regarding violence, two instances in Journey to Italy that might be overlooked are of some note. First, in a fascinating case for euhemerism, Sade likens the myth of the Minotaur to the story of a modern and real monster: Gilles de Rais, or Retz (1404-1440), a wealthy nobleman, war hero comrade of Joan of Arc, marshal of France, and a serial killer who sodomized his child victims (purportedly a hundred or so of them) before committing ritual murder. Sade reflects that all myths must have some origin, and he surmises that the combination of man and bull in the Minotaur, symbolizing moral monstrosity through physical hybridity, ultimately points to an earlier "Marshal de Rais." It was the "frenzied passions" of Rais that brought him "to that barbarous derangement that finds charm in the destruction of the object that satisfies our senses or rather that tastes none except in excesses of the most considered cruelty." Sade's later writings will develop at length this notion of "considered cruelty": cruelty committed not out of anger or immediate instinct but indulged reflexively and for pleasure. In Justine, the eponymous heroine exclaims credulously when an inmate in the convent where she has landed explains the penchants of the four odious monks that oversee the establishment: "Good heavens! Murder, the most execrable of crimes would thus be for them as for the famous Marshal de Retz a sort of voluptuous pleasure [jouissance], the cruelty of which, exalting their perfidious imagination, might plunge their senses into a livelier drunkenness?"181 In his Italian manuscript, Sade deems such monsters to be sports of Nature that happily only appear once in a thousand years. Many of his libertine protagonists are explained precisely as such freaks, monstrous in the sense of rare, but no less natural for that. In Juliette, Gilles de Retz ends up on a list of historical villains that include emperors Nero, Tiberius, and Heliogabalus, all of whom derived sexual enjoyment from the spectacle of pain. If "fools" object that these are "monsters," the designation is merely conventional: "Yes, according to our mores and our way of thinking, but relative to the grand designs that Nature has for us, they were naught but instruments of her intents." 182

Second, there is the case of the small bow that Sade observes among other weapons in the Castel Sant'Angelo in Rome. This device belonged to "a Spaniard whose sole pleasure consisted in shooting, by means of this bow - without any other intention than that of gratuitous destruction - several poisoned pins into the streets and into crowds where he found 
himself, or in public places, or as people were exiting church." Sade finds that "this bizarre mania to do evil for the sole pleasure of doing it is one of the least understood of human passions and consequently the least analysed, and yet I would dare to think it possible that it should be classed with the common deliria of our imagination." Common perhaps, but at the time of composing his companion to Italy, Sade also - paradoxically - considers this delirium sufficiently rare that he need not analyse its mechanisms. The topic evidently appealed to him sufficiently, however, that he would subsequently return to it ad nauseum.

These interesting examples aside, the greatest single source of what might be called sublime violence comes from the Roman emperors. In general, there was a sort of cruel utilitarianism to Imperial projects, with sacrifices of the labourers calculatedly built into engineering projects, for example. Ancient wonders and horrors go together. Sade's observations in this regard echo his notion that science and art require a certain tolerance - an allowance for necessary cruelty and licence - if progress is to be made or worthy and magnificent objects created. The specific emperors who fascinated Sade most, nonetheless, were those whose decadence and perfidy stood in stark contrast to the Stoic virtues of, say, a Marcus Aurelius. For their exploits, Sade culled from the Imperial biographies of Tacitus, Cassius Dio, and Suetonius, from whom he took copious notes. On Nero, for example, Sade draws from Tacitus and considers what the emperor "out of a barbaric principle much more than a religious one" did on Marius Hill in Rome, where he "entertained himself by lighting his gardens with the bodies of Christians, positioned at intervals to be used as torches." He will return to Tacitus's description in an explanatory note - a note that also recounts Lucian's characterization of early Christians in Rome as a ragtag assortment of feral and fanatic vagabonds - when his heroine Juliette visits Marius Hill and sees where Nero "amused himself by illuminating his gardens with the bodies of the first Christians." 183 Juliette wishes she could witness such a spectacle, for she, too, despises the "infamous sect." ${ }^{184}$ In Journey to Italy, Sade's philosophical critique on this matter stops just shy of such a pronouncement: he wonders whether "the present-day despots will perhaps revive on the same spot, over which they now rule" such an inhuman spectacle and fate "for those who might undertake to attack the religious structure that serves as the foundation of their throne."

Sade almost invariably positions popes as latter-day emperors, and they provide their own examples of horrific violence. An outstanding case is Urban VI (c. 1318-1389), a central figure in the Great, or Western Schism, and in Sade's cutting characterization "villainous in the manner of Nero." On seeing the remnants of Urban VI's sarcophagus in Saint Peter's Basilica in Rome, Sade points out that one cannot help "but recall his horrific cruelty towards the six cardinals who were not of his party and whom he had arrested and condemned to such horrific torture that he could not find anyone to carry out his barbarous plans." Sade expands on the cruelty of this pontiff in a note, where he adds that Urban VI ordered the executioner of Luigi Donato, cardinal of Venice, to "torture him until I hear his cries" (original emphasis). This supreme pontiff then strolled calmly in the gardens nearby the dungeon where the act was taking place, breviary in hand, listening in apparent satisfaction. Like their ancient Roman precursors, the exploits of many popes who fascinate Sade are a juxtaposition and often combination of violence and sex. Of Alexander VI (1431-1503), pope from 1492 until his death, Sade concludes that he can only be compared to "the likes of Tiberius and Caligula." Our author informs his reader that this pope was a Spaniard, native of Valencia, and bore the name Borja from his mother's side. Italianized, this name became Borgia. Hardly celibate, he fathered numerous children, including the infamous Cesare Borgia. Sade tells 
us that Pope Alexander VI had four sons, among them Cesare, and also a daughter with "a Roman woman named Vanozza." He elaborates that "in their infancy" all five children were made to serve their father's "incestuous and sodomitical passions." This pope also raped and murdered his male and female political rivals alike. More picturesquely, he once hosted an "infamous supper" that involved fifty courtesans. They first danced naked, and then after this dancing candelabras were positioned on the floor and chestnuts were scattered about, which the nude courtesans on their hands and knees proceeded to gather up, weaving through the burning tapers. Sade explains that there is an account of this dinner that "can still be seen in the Vatican archives," "the description of which has been handed down to us by Burchard." The reference here is to Johann Burchard (c. 1450-1506), papal master of ceremonies in the Vatican, who had chronicled in Latin the covert history of the papacy. Sade's actual source, however, was the translation and recapitulation of these records in Mémoires secrets (Secret memoirs) by Boyer d'Argens. ${ }^{185}$ Such was clearly the sort of material that Sade hoped his friend Iberti would unearth for him, although the Inquisition curtailed that poor doctor's mission. These sorts of antics and episodes, moreover, were evidently what Sade had in mind when he subsequently cast the reigning pontiff in his own day, Pope Pius VI (1717-1799), as an inhuman libertine extraordinaire in the pages of Juliette. This pontiff's given name, which Sade uses in his novel, was Giovanni Angelo Braschi; he was elected on 15 February 1775, donned the tiara a week later, and took possession of the cathedra on 30 November, with our marquis in attendance at the ceremony. In Juliette, Pius VI sodomizes the heroine, dines on a fulsome mélange of dainties and her excrement, and declares of his sanguinary and voluptuary tastes, "Blood must flow for orgies to be good. Seated on Tiberius's throne, I imitate him in my sensual pleasures, and, following his example, I know not a more delicious discharge than one in which sighs are mingled with the plaintive tones of death." ${ }^{186}$

\section{Extraterritorialities}

Sade's philosophical concern about monastic and conventual perversion and the deleterious effects on population of religious claustration also provided content for his later writings. To Sade's thinking Italian monasticism and its "odious cupidity" was implicated in seduction, "murders," "abductions, rapes, acts of sodomy, poisoning, adultery, swindling, incest," and overall "injustice." These crimes are "always unpunished because of the unpardonable toleration of the laws against these wretches." They are also precisely the crimes that Sade would later depict in meticulous detail - and as often enough carried out by monks. In fact, for Sade there is a hazy line between libertine and monk, or rather, no distinction whatsoever except that the latter is hypocritical and his criminal behaviour is overlooked, whereas the former is more open, honest, and liable to be persecuted and prosecuted - as Sade felt himself unfairly to have been persecuted and prosecuted. Sade hardly invented this parallelism, and plenty of licentious libertine tales were set behind monastery doors or convent gates, from Vénus dans le cloitre in the late seventeenth century through numerous eighteenth-century examples. The most philosophical version is probably from Histoire de Dom Bougre, Portier de Chartreux (Story of Dom Bugger, the Carthusian's porter) (1741) - possibly authored by Gervaise de la Touche (1715-1782), a lawyer at the parlement in Paris - where a hidden harem of nuns deep within a monastery and known as la piscine or "the pool" serves the lubricious desires of monks. According to that author, the nuns themselves tasted a freedom in this enclosure that a life of marriage on the outside would have never have afforded them. ${ }^{187}$ 
In his licentious writings, Sade would simply fold together the various aspects of monastic criminality - viciousness and sexual depravity - with the claustrophobic atmospherics of the monastery as setting. Italy was where he began to work out the poetics of isolated and carceral spaces that would become an essential feature of his oeuvre. He evinces a fascination with zones outside of policing powers - lawless or extraterritorial zones, such as the catacombs under the Church of San Lorenzo in Rome, which are narrow, twisting, and rumoured to stretch all the way to the sea (albeit few people, opines our author, would be curious enough to test this hypothesis). Of these "impenetrable subterranean passages," Sade opines that they "would surely be perfect safe havens for crime if the monks of the building above had some inclination to commit it." He supposes them "upright fellows," but says that his confidence in this view would falter should he have something on him "that might excite their cupidity." These extraterritorial spaces need not be monastic or conventual, however. Sade describes, for instance, the vaults of a ruined ancient estate on the outskirts of Rome that "today constitute an asylum for debauchery and crime." Or consider this passage about Florence, which foreshadows Sade's libertine novels with precision: "The thick and remote walls of the vast palaces of the nobility hide, it is said, plenty of horrors. And how many unfortunate young women, brought furtively and under cover of night into these criminal enclosures have left therein their honour and health? Shortly before my arrival, an eight-year-old child had lost her life a fortnight after suffering forced indecencies in one of those palaces." Sade claims that this sort of trade was facilitated by two women who had been recently arrested and that an "enormous number of girls had been victims of their seductions." One girl, but ten years old, had been submitted to "the brutal and anti-natural caprices of a Florentine lord who had left her completely maimed." Anti-natural in this context simply means sodomitical.

At the same time, there was plenty in the archaeological remains of Roman and Hellenistic antiquity to inspire a touring hedonist. There were ruins throughout Campania, in particular, that recalled an earlier era of luxury, excess, and licence, such as "that famous city of Baiae, centre of delights and of sensual pleasure, where the Romans came to surrender themselves to debauchery of the most audacious and varied sorts." Examining the remnants of rooms that he assumes belonged to "one of those voluptuary houses located in this charming city," Sade spells it right out: "It was here that, in the loveliest of locations, sheltered from all the inclemency of the air and enjoying a wonderful coolness, our heroes of Antiquity were no longer but libertines." The libertine spot par excellence, however, is the island of Capri, where the emperor Tiberius, "master of the universe," withdrew during the last days of his reign to indulge in all manner of vice and "voluptuous deviations of his senses." Following an account by Tacitus, Sade reports that the emperor "was not content with the willing victims that his emissaries placed all over Italy brought for his lust, but even had children abducted from the bosom of their families by his slaves when they refused to hand them over politely." These are the tactics that Sade's four repellent protagonists will use in Les 120 journées de Sodome to build their harem, and the similarities between Tiberius's libertine idyll and Sade's first licentious - and in many ways most shocking - work hardly end here. In particular, there is the sheer grotesquerie of Tiberius's pleasures, which find an echo in Sade's mature writing. Suetonius detailed preposterous extravagances such as a pool stocked with young boys who were instructed to lick and nibble at the emperor's genitals as he swam past. The tyrant also reputedly had himself fellated by unweaned infants. ${ }^{188}$ The emperor held debauched court in a grotto with seats fashioned into the rock. There he could watch troops of boys and girls engage in all manner 
of venery. This grotto was linked to hidden chambers where Tiberius could enact his fantasies, once his imagination had been fired. In Les 120 journées de Sodome, the protagonists listen to tales of lubricity, watch their victims perform the same, and then retreat to recesses where they mimic these stimulating spectacles - that is, they mimic them if they are able, for Sade's protagonists include not only indefatigable, superhuman libertines, but also those who like Tiberius, are etiolated by their excesses and on the brink of utter impotence. In short, the Isle of Capri contributed crucial characteristics to Sade's imaginary Chateau Silling, the setting for sadism's seminal document. Hidden in the Black Forest, far from publicity and the law, Silling is a phantasmagoric amalgam of Sade's own Chateau La Coste, where we know him to have been up to various misdeeds, the prison cell in which he spent years as the self-perceived victim of his mother-in-law and of a monarchical power that he could hardly deem enlightened, and the emperor Tiberius's sun-soaked, carnal, and vicious retreat. ${ }^{189}$

\section{Paragons}

Tiberius's sojourn on Capri also provided Sade with a model of suffering femininity that will be familiar to anyone who has read his novel Justine or its relations. In Suetonius's biography of the emperor, Mallonia was a married woman who captured Tiberius's attention on the island. ${ }^{190}$ When she rejected his embraces, he forced himself on her in his preferred manner as a superannuated debauchee: cunnilingus. As Martial elsewhere makes clear, this action was considered degradingly passive, and Tiberius was reputedly mocked for his ways in an Atellan Farce. In any case, when Mallonia's resistance continued, her tormenter mocked up a trial, and she ended up taking her own life, stabbing herself. Similar to Lucretia, but the details of her plight more sordid, Mallonia is a paragon of sexual virtue that Sade will explore in terms of characterization and psychology in his later writings. As usual, Sade discovers Christian counterparts as well, and these he more openly derides in the pages of Journey to Italy. The best example is Agnes, who as a Christian, is "sent by the prefect of Rome to be raped" in the brothel district, which Sade notes, is the site of contemporary Piazza Navona. Of Agnes and her ilk, Sade explains that these "young virgins made such a fuss about modesty" and the "moral dissoluteness" of the Romans was "at such a high degree" that their "reckless sensuality increased with the barbaric pleasure of wresting from these young victims that which they deemed most precious." In legend, Agnes is rescued by an angel just as a young man is about to ravish her. The young man is struck dead, but miraculously resuscitated thanks to Agnes's prayers. This is the sort of myth of supernatural rescue and redemption that Sade will emphatically reject in his libertine writings as mere fiction. Nobody ever comes to save the persecuted Justine - except to torture her the more. Murderers and rapists are unrepentant and generally go unpunished.

In novels, poetic justice or the lack thereof is an authorial decision. The former is rarely a feature of reality; the latter is almost a given. Further, Justine sticks to her virtue to the point that the reader cannot help but surmise that she is complicit and takes pleasure both in the acts to which she is submitted and in her own pain and humiliation - the narrative occasionally hints openly in this direction. Of Agnes and her alleged rapist, Sade similarly and cynically implies that all that happened was that the two had copulated and that the young man simply succumbed to a post-coital syncope: he was "exhausted from the pleasures that he had just tasted with the young saint," who had "barely [...] left childhood" and had, after all, "the most interesting face." Mallonia, Agnes, and others like them that 
Sade encountered while researching his guide to Italy are key precursors and models for what we might call the Justine-type. In them all, Sade found an opportunity to satirize selfrighteous, hypocritical, and repressed sufferers and, more intriguingly, the social expectations and contradictions that create them. If in terms of more chronologically proximate literary genealogies, Justine appears close kin to Richardson's sentimental heroines - Pamela and even more so the kidnapped and raped Clarissa, a sort of modernized Lucretia who dies of chagrin - there is also in Justine an element of Henry Fielding's send-up of Richardson in the character of the gold-digging, faux sentimental, and seductive mock prude Shamela (rhymes, of course, with Pamela). For his part, Sade never denies the force of sexual drive in women, and he tends to ridicule attempts to control it. Coming across chastity belts on display in Florence, he labels the devices an invention of "Italian jealousy." He adds that they lead to outcomes opposite the intended one: suppression only exacerbates female impetuousness; sexual control so asserted is the more inevitably thwarted.

In the Italian manuscript, some women stand out as heroic in this regard. Matilde di Canossa purportedly separated from her second husband, Welf V of Bavaria (1072-1120), when he proved unable to perform his conjugal duties. The Margravine of Tuscany displayed herself naked before him on a table, wagging her rump, and when he still did not react in a manner she thought appropriate, she gave him a slap and exited in a fury. Sade sifts through various historical accounts of Matilde and decides that Welf's impotence, as described, was the most likely or vraisemblable reason that she dismissed her husband. But Sade's best model for heroic female sexuality was, once again, classical: Messalina, the lascivious third wife of Emperor Claudius (10 BCE-54 CE). In Rome, Sade comes across the ruins of chambers that recall to him the lupanars where the empress in Juvenal's telling would surreptitiously prostitute herself under the name Lycisca or She-Wolf. She would always be the last to depart, in the words of the Roman satirist, "exhausted by the men but not yet satisfied." 191 Sade expands that it was here that Messalina "challenged the entire city of Rome to venereal combat." He stops short of open admiration, telling his reader that he must limit "reflections too risqué for your delicacy, yet not expansive enough, I will admit, for the ardour of my imagination."

The satirical persona in Juvenal's work was criticizing Messalina as the nadir of female perversity and decadence. Juvenal's sixth satire is an over-the-top rant against the sexual mores of contemporary Roman women, advising suicide or homosexuality as better options than marriage. In his licentious writings, however, Sade will hold Messalina out as a positive role model. She is mentioned on numerous occasions across Sade's libertine oeuvre. For example, in La Philosophie dans le boudoir, the empress is invoked when the debauched instructor Madame de Saint-Ange explains to her young charge, Eugénie, that if she wants to approach immortality that "it is by fucking, my dear, that you will remain in men's memory." Lucretia and her sort are soon forgotten, whereas the likes of Messalina and Theodora - the sixth-century Byzantine empress also reputed to have worked in a brothel - enjoyed themselves when alive and are still recalled with pleasure. ${ }^{192}$ In Juliette, both Messalina and Theodora return as "the most celebrated whores of Antiquity," and the heroine exhorted to pattern herself on them. At the moment that Juliette sets off on her Italian travels - following in Sade's own footsteps, but with considerably more action on the road - Messalina, along with Emperor Caligula (12-41 CE), is mentioned as an inspiration once more. Later in Juliette, Pope Pius VI in the chamber reserved for his carnal pleasures in the Vatican hangs a painting of the empress that "flatters his penchants": "Close to Teresa in Ecstasy was seen Messalina being sodomized." 193 


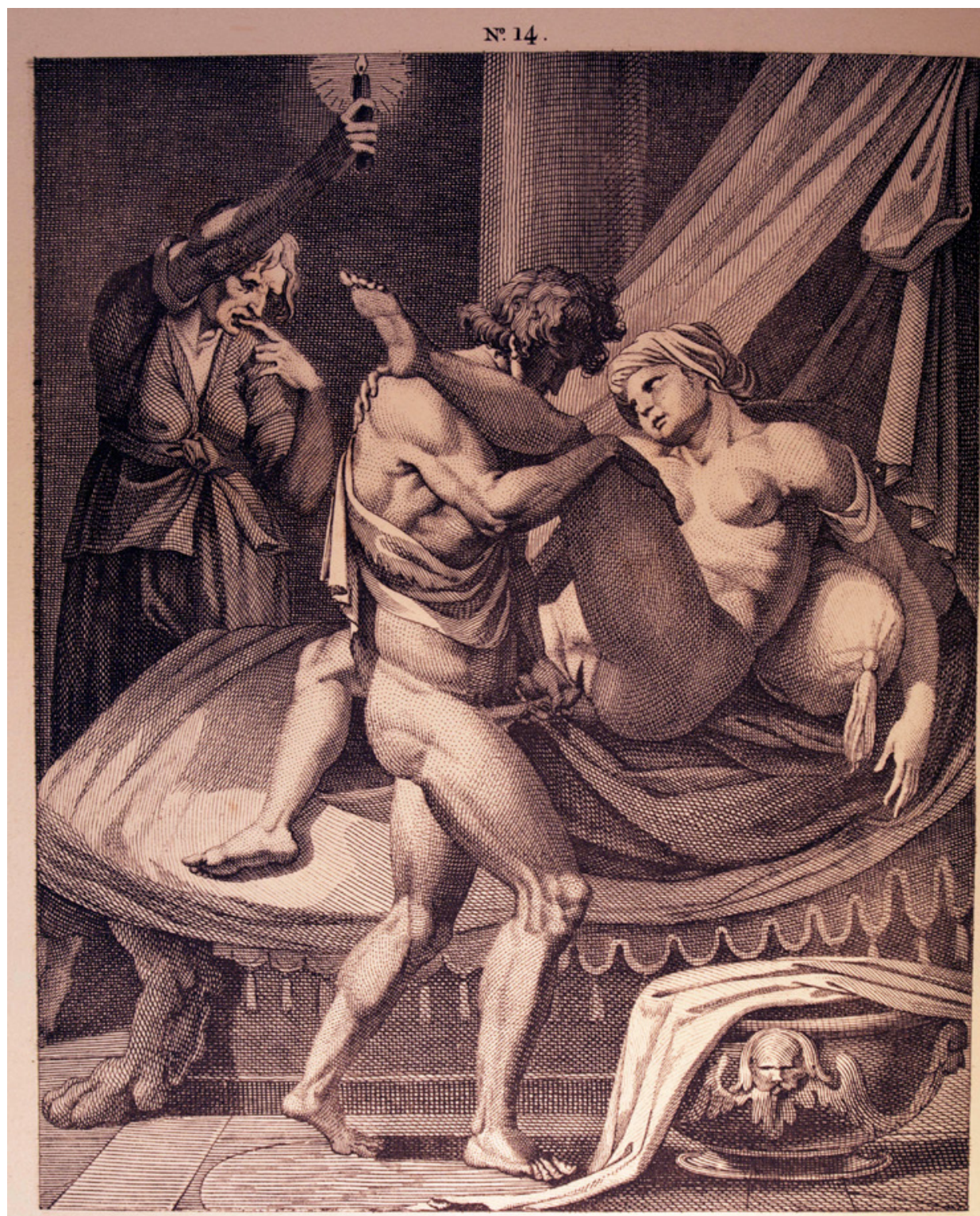

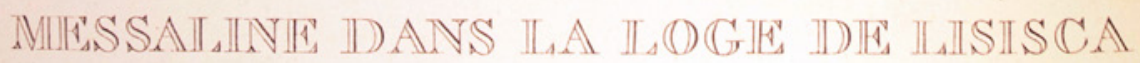

Figure 0.7. Empress Messalina working in a brothel, from Anon. [Jacques Joseph Coiny?], L'Arétin d'Augustin Carrache (1799). 
Ultimately, models for Sade's libertine heroines needed not only voracious sexual appetites, but also to demonstrate a cruel demeanour and a strong affinity for violence. Sade came across various avatars of the latter in his research for Journey to Italy. Alongside shimmying naked in front of her hapless second husband, Matilde di Canossa did not shy from violence: suspect in the assassination of her first husband Godfrey the Hunchback, she was also famously militaristic. Similarly, Queen Joanna I of Angevin Naples (1328-1382) was four-times married, oversaw numerous military conflicts, and was known for her violent streak. Pietro Giannone (1676-1748), a philosopher, historian jurist, and Sade's source on Joanna, claimed that she was behind the strangulation of her first husband, Andrew of Calabria (1327-1345), son of King Charles I of Hungary (1288-1342). ${ }^{194}$ Perhaps the best precursor of female perfidy was Tullia, daughter of Rome's sixth king, Servius Tullius (assassinated 535 BCE). In Livy's account, Tullia and her husband Lucius Tarquinius Superbus (died 495 BCE), the seventh and last king of Rome, first slayed their own siblings, who would otherwise vie with them for power. Next Tullia encouraged her husband to murder her father so that he, Lucius, could ascend to the throne. Sade notes in his visit to Rome that "you pass by the very spot where the barbarous Tullia, returning from the Senate where she had decided to appear in order to encourage Lucius, her husband, to get rid of Tullius, her father, and to rule in his stead, forced the driver of her carriage to roll over the corpse" - of her own father. Sade claims that "it is fortunate for humanity that Nature no longer produces such monsters." Nevertheless, in his licentious writings, he would happily produce such monsters himself. ${ }^{195}$ The amoral and consciously ruthless contrast to the Justine-type, we might here posit the Juliette-type as a latterday, grotesque version of the Venus of Cnidus (or Knidos), a statue supposedly modelled on various beautiful women, whose best features were artfully and effectively combined. ${ }^{196}$ Sade's composite of sexuality and cruelty is, moreover, not so much a negation as an inversion of the sentimental model of femininity that was at the heart of the sadistic investment in the "interesting." Where the "interesting" woman modelled an eroticized suffering that piqued both the pity and the libido of the observer - compounding sensible stimulation - the pitiless one combined virtuosic detachment with a joy in inflicting pain.

Notwithstanding the existence of certain historical exemplars, female cruelty for Sade was not limited to heroic freaks; for Sade, it was generalizable. Having noted in passing in his Italian manuscript that women seemed particularly fond of attending public executions in contemporary Rome, Sade would return precisely to this point in La Nouvelle Justine, once again linking the gladiatorial spectacles of the ancients and modern penal entertainment. Today's women flock to witness what are deemed juridical assassinations: "They therefore have more of a penchant for cruelty than we do, and this because they have a more sensible physiology [l'organisation plus sensible]. This is what fools fail to grasp." ${ }^{197}$ Here we glimpse one of the most intriguing and ambiguous heritages of Sade's Journey to Italy, namely, his discovery and depiction of divergent models of femininity. Sade encounters and often lingers over women who defy prevalent cultural and literary notions of sexual virtue and whose actions belie the thesis of female humanity as the tremulous embodiment of sensibility. For Sade, women are far from passive vessels or inherently pitiful; they are highly attuned and active seekers of sexual pleasure and of cruel delight.

\section{Fictions}

The Marquis de Sade's reputation has long been that of extreme misogyny. Considering the rapes, mutilations, and murders of women that are the hallmark of his writings from 
Les 120 journées de Sodome forward, this reputation is entirely understandable. For good reasons many feminists have excoriated him. Moralists have argued for Sade's works to be banned or, at the very least, handled with care and their content not wished away as philosophical allegory or reduced to formal play. ${ }^{198}$ The reality of the Marquis de Sade's oeuvre, permit me to say, is more complicated. In the reception of Sade in the 1960s and 1970s, there was a biographical, psychologizing strand that found in the marquis misogyny, but also a profound identification with his long-suffering and endlessly displaced anti-heroine Justine. ${ }^{199}$ Far-fetched as it may seem on the face of it, this identification has some verisimilitude. However deserving of opprobrium we may think him or his writings, did Sade not see himself as persecuted by his mother-in-law and malign authorities, forced on the run, and unjustly incarcerated? In certain respects, Sade's actual journey to Italy and its aftermath does mirror his multifariously martyred character's experiences, albeit in extravagantly hyperbolic terms. At the same time, Sade evidently projected onto Juliette, ruthless and liberated, an idealized self: like her sister ever in transit, but roaming without a care and enjoying at will her various preferences and the radical libertine freedom denied her author. In short, the road as a narrative device is crucial to the centrepieces of Sade's mature career as a licentious writer: Justine, La Nouvelle Justine, and Juliette.

With their meandering structure and repetitive episodes, these works follow a logic of amplification rather than one of psychological development or revelation. In this regard, they owe much to the picaresque, the other great modern tradition of the novel, alongside and predating the sentimental with its archetypically epistolary format. ${ }^{200}$ Initially associated with Spain and the seminal, anonymously published La vida de Lazarillo de Tormes $y$ de sus fortunas $y$ adversidades (The life of Lazarillo de Tormes and of his fortunes and adversities) (1554), with its roguish anti-hero and sadeian extended title, the picaresque continued to thrive and adapt in the eighteenth century. Standout examples in Sade's day include The Expedition of Humphry Clinker (1771) by Thomas Smollett (1721-1771), much of which takes place in Italy, and Diderot's Jacques le fataliste et son maître (1796) (Jacques the Fatalist and His Master). Composed starting in the 1760s, published partially in serial installments in the late 1770s and as a whole only posthumously, playful and philosophically risky, Diderot's novel puts forward an argument for determinism that is jocular kin to the sordid fatalism of Sade's tales - not without their dark and absurdist comedy. Violence, often painfully slapstick, was essential to the picaresque as a form of brutal, satirical critique of inexorable social oppression. The genre was also replete with bodily humour, frequently grotesque and scatological, which Sade easily adapted to his idiosyncratic anal interests.

In the eighteenth century, travel writing and the picaresque existed in uneasy symbiosis. For Humphry Clinker, Smollett draws on his voyages on the Continent, chronicled in his Travels in France and Italy (1766). He, like Sade transitioning from his Italian guidebook to his later fiction, changed much in moving from one genre to another. Precisely what most travel writers suppressed were the picaresque moments of their voyages: encounters with banditti, road mishaps, dubious sexual encounters, getting ripped off, disgusting meals, and lice-infested lodgings. Or rather, these picaresque moments occasionally bubbled to the surface, providing comic relief and a dose of realism. Moreover, who truly believed that the grand tour was nothing but art, natural beauty, the satisfaction of scientific curiosity, and cosmopolitan cultivation? If such moments do briefly pierce the façade of smooth travel, the picaresque is nothing but the bumps. In this regard, Sade's lewd, bloody, and excremental adventures might be seen as a transmogrification of travel writing: they developed 
the genre's picaresque possibilities via the discourse of philosophical libertinism and a thorough steeping in the cruelties and aberrancies encountered in his research.

There were other literary precedents and paradigms that Sade began to explore in his Italian project that would add to the symbiosis that is sadism. Although there was no genre or subgenre of the sentimental novel that went by the name "Gothic" - a later coinage there was a vogue for the strange and at times terrifying in poetry, drama, and prose fiction that in France was known as "English" taste. One of the most influential works in this trend was the lugubrious lengthy poem The Complaint: or, Night-Thoughts on Life, Death, and Immortality (1742-1745), often referred to as Night-Thoughts, by Edward Young (1683-1765), and translated into French as simply Les Nuits d'Young (Young's Nights). There were also prose imitators of the supposedly dark English tales as well as dramatic conjurers of the English stage, which was known in France to be bloody and horrific. The prolific François-Thomas-Marie de Baculard d'Arnaud (1718-1805) wrote in both genres, generally eschewing outright violence for lugubrious atmospherics. His tragedy Euphémie, ou Le Triomphe de la religion (Euphémie, or the triumph of religion) (1768), for example, is set in a gloomy convent. D'Arnaud's prose works included novellas such as Anne Bell, histoire angloise (Anne Bell, an English tale) (1770), where the abused heroine at one point traverses a "vast cemetery," is overcome with exhaustion, and takes a seat "under the vault of an ancient monument that you might have thought the asylum of death itself." 201 There she breathes in the "sombre horror" and glimpses at the "back of this tunnel of sorts, a long line of tombs and sepulchres that came to an end in a deep pit in which were heaped and confounded piles of bones and fragments of coffins." ${ }^{202}$ Sade registers a similar appreciation for darkness and morbidity in the posed skeletons that he sees in Santa Maria della Concezione dei Cappuccini in Rome, an installation that may have been the handiwork of a German monk but that Sade judges to be "worthy of an English brain." Years later Sade would go on to praise the Gothic genre or what he described as these "new novels, the entire merit of which just about consists of witchcraft and phantasmagoria," in his critical essay "Idée sur les romans" (Thoughts on the novel) of $1800 .{ }^{203} \mathrm{He}$ considered The Monk (1796) by Matthew Lewis (1775-1818), to be the peak of the genre, better than the "bizarre flights of brilliant imagination" of Ann Radcliffe (1764-1823), although Sade was not without apparent admiration for these dark whimsies as well. ${ }^{204}$

Our marquis was thus certainly not alone in his regard for dark atmospherics. Other writers, exposed to Italy either through their travels or simply adapting what they had read in travelogues and guidebooks, pursued similar routes. The pulsing backdrop of Radcliffe's The Italian, or the Confessional of the Black Penitents (1797) is the vicinity of Naples, where the volcano on a still night on the bay sets the scene, visually and aurally, through invocation. Vesuvius breathes like a sleeping beast, with "hollow murmurs" and an occasional "groan," and releases "at intervals its sudden flame on the horizon," then reverts to darkness. The solemn scene induces a "particular awe" and pensiveness. ${ }^{205}$ Like Sade, Radcliffe was drawn in her fiction to the dark spaces of Catholicism, to the criminal aspects of fanaticism, and put in play evocative ruins, sublime Nature, and a victimized and maligned heroine whose will is tested at every turn: kidnapped, kept against her will in a cruel convent, and generally abused. In his libertine works, Sade merely took to extremes these devices that others had used, but the seed had long since been planted. In Justine, Juliette and other of his licentious writings, the examples that Sade encountered and described in his Journey to Italy would be mingled with and reflect his own carceral reality. They presumably served as a protest against and escape from this reality as well. 
Given the satirical thrust of Sade's libertine quill, we might consider his take on the Gothic novel as less an extension than as a subversion, just as he undermined the discourse of sensibility by stretching and twisting its fibres. His licentious works would not only take Radcliffeian devices to gruesome and graphic extremes - flaying the genre to reveal the underlying nervous anatomy in excruciating detail - they would also reveal themselves to be the savage kin of Jane Austen's ironization of Gothic topoi and tropes, as in Northanger Abbey (1803, published in 1817). The acme of such ironization is the damage that Sade inflicts on the enlightened notion of Nature as beneficent force and guide. Those who would affirm this notion, as it turns out, merely suffer from a peculiar form of human credulity: believing one's own fabulations as if they were empirically tested and philosophically true. Certainly, others had had their doubts. Voltaire's Candide was famously a response to the fatuousness of the theodicy of Gottfried Leibniz (1646-1716) when, for example, it came to facing the devastation wreaked on Lisbon by the earthquake that struck that city in 1755 . Volcanic Italy provided Sade with ample evidence and numerous examples of Nature as a mephitic force. The Grotta del Cane was toxic to life and the sulphurous exhalations of the Campi Flegrei confirmed that what the credulous call Hell was a natural phenomenon. Why would the happy abundance of Campanian fields be a better model for humanity than the former? In La Nouvelle Justine, an Italian chemist named Almani, in observing Mount Etna's destructive powers, explains that he will not have anything to do with being Nature's lover in the philosophical vein but rather aspires to serving as her executioner: "Study her, follow her, this atrocious Nature, you will never see her create but to destroy, never arrive at her ends but by murders, and, like the Minotaur, never fatten herself but on the unhappiness and destruction of men." ${ }^{206}$ Sade's heroes and heroines in general identify with and mimic Nature's malign powers.

Such identification marks the culmination of Juliette's grand tour of Italy: visiting Vesuvius. Like her creator, she sets out "early in the morning" to climb the volcano. The night before she had but little rest, engaging instead in various wanton and degenerate activities. In any case, Juliette avers, "One doesn't sleep when planning a crime." ${ }^{207}$ Her accomplice is a fellow female reprobate and Englishwoman named Clairwil, based perhaps on the lovely Sarah Goudar. ${ }^{208}$ Their victim is Olympe, herself their former partner in libertinism. It would seem that the author allows Juliette to fill in details of the climb that are missing in his Italian manuscript. She remarks that the trip up the mountain is "an awful chore": "always in ash up to your neck, four steps forward and six steps back, and constantly fearful of being swallowed up alive by some lava flow." ${ }^{209}$ At the edge of the caldera, Juliette and Clairwil strip their sacrifice. They "molest her lovely chest," "cudgel her charming ass," "prick her buttocks," and Juliette "bites her clitoris until it bleeds." After two hours of torture, the treacherous women grab Olympe by the ropes that bind her and toss her into the volcano. Like the vicious Pope Urban VI enjoying the screams of his tortured enemy, they listen to "the sound of her body strike and tumble jerkingly on the sharp angles that bounced it from one to the other, ripping her to shreds." 210 This aural feast sends the women ecstatically into each other's arms, uttering "lubricious words" spiced with "a few blasphemies," as they enjoy themselves utterly. ${ }^{211}$

Sade's journey to Italy was not made under the best of personal circumstances, and there was plenty that dismayed or disappointed the Count of Mazan. Vesuvius, for example, did not put on its most sublime and destructive spectacle for him. Yet there was much that he enjoyed and appreciated on his grand tour, and as it turned out, this was the last time for many years that he was to truly taste freedom. When Sade returned to climb the volcano 


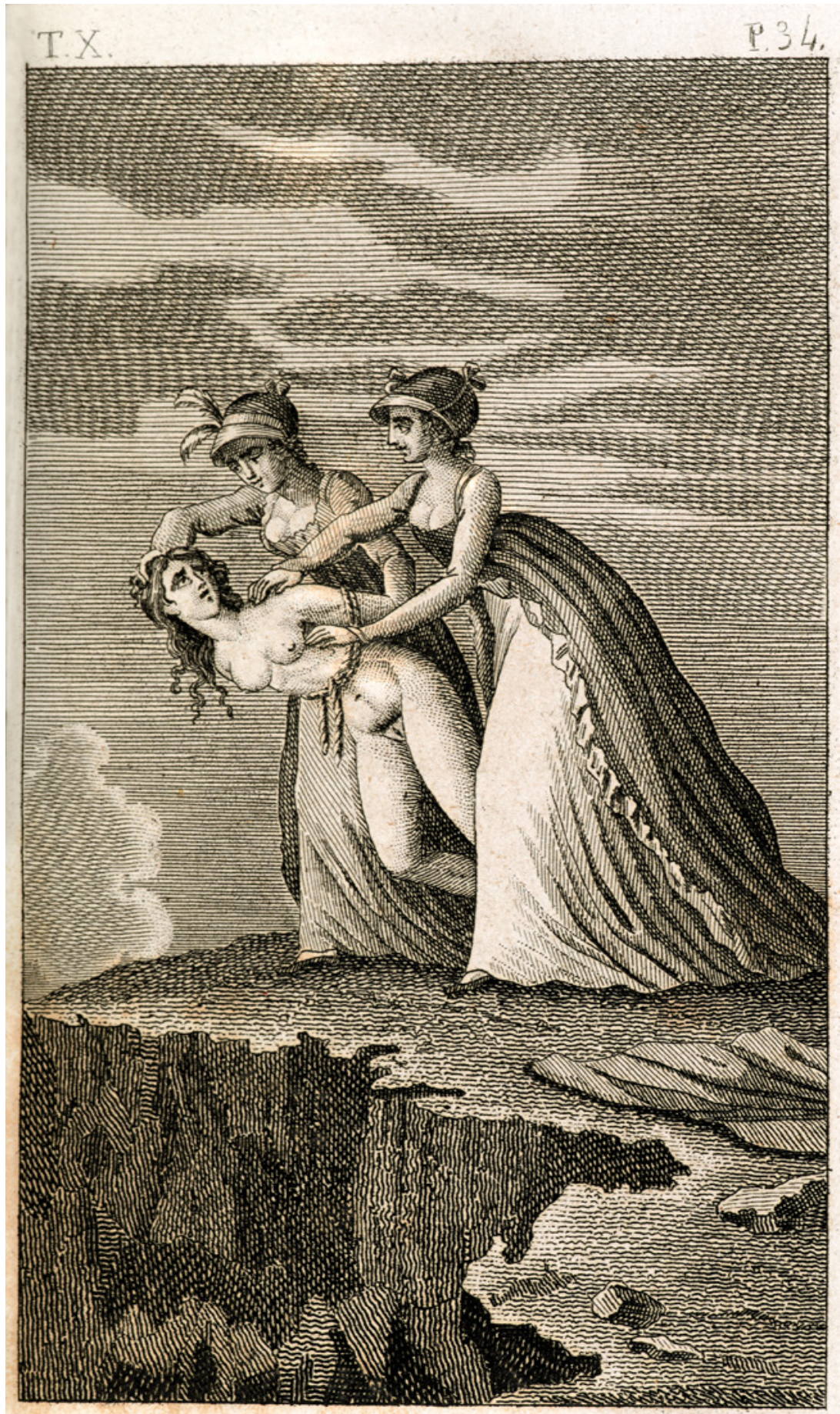

Figure 0.8. Juliette and Clairwil sacrificing Olympe to the volcano, from Marquis de Sade, L'Histoire de Juliette (1797). By permission of the British Library Board/Shelfmark P.C.27a.37. 
in print, some twenty years later, he seized an opportunity to rewrite this episode from his life in fictional terms. That he projected himself onto Juliette, whose bacchanals make the affaire de Marseilles look like innocent play, appears clear. Her journey, including the trek up Vesuvius, was to an extent a fanciful correction of Sade's reality. More ambiguously, that there was also a glimmer of him in Olympe - betrayed, tortured, and tattered - seems less a correction of reality than an admission of fiction's utter impotence to put the world right.

In any case, before his full realization that malign powers, at least in his estimation, were working to ensure a lengthy incarceration, Sade had already gathered significant material on ancient lubricity and cruelty - not to mention on later ecclesiastical and secular malfeasance and decadence - to amply inform his subsequent licentious writings. These began to take concrete shape in 1785, and it is worth emphasizing that Les 120 journées de Sodome - the outrageous first burst of his truly sadistic writing activity was, like the Journey to Italy, also planned, partially composed, and never completed. Relinquishing the hope that he would return to his philosophical travelogue once he was released and become a proper man of letters, Sade began, instead, to forge the clandestine literary career that would eventually secure his name for posterity. These two projects are not only proximate: they are temporally, thematically, generically, biographically, and, in the end, psychologically utterly entangled, and in this grey space of dawning despair, sadism was born.

\section{NOTES}

1 The play is included in vol. 15 of Sade, Euvres complètes, ed. Annie Le Brun and Jean-Jacques Pauvert (Paris: Pauvert, 1986-1991), 7-114. A contemporary review found "interest and energy in this play," while judging the depiction of Count Oxtiern, the title character, to be "revoltingly atrocious." Besides, on the second night of the performance, some joker had yelled out "Lower the curtain!" at the beginning of act II - an exclamation that was mistakenly taken as an order by the "theatre boy" and led to unhappy tumult. In the end, however, the applause of the majority drowned out the tepid protests of the minority. As reported under the rubric "Théâtre de Molière," in La Gazette nationale, ou Le Moniteur Universel, no. 310 (6 Nov. 1791): 1293-4.

2 Sade, Voyage d'Italie: précédé des Premières œuvres; suivi de Opuscules sur le théâtre, eds. Gilbert Lely and Georges Daumas. (Paris: Tchou, 1967); Sade, Voyage d'Italie, 2 vols., ed. Maurice Lever (Paris: Fayard, 1995). A new French edition of the Voyage d'Italie, edited by Michel Delon, is not as comprehensive as the Lever edition but has a more thorough critical apparatus; it was published while the translation presented here was in production (Paris: Flammarion, 2019).

3 Les 120 journées de Sodome, ou L'École du libertinage, written in 1785, in vol. 1 of D.A.F. Marquis de Sade, Euvres, ed. Michel Delon (Paris: Gallimard, 1990). Unless otherwise specified, all translations from Sade's Euvres, and other French works, are my own. The only available English translation for decades was Austryn Wainhouse and Richard Seaver's somewhat quirky rendering in The 120 Days of Sodom and Other Writings (New York: Grove Press, 1966). Will McMorran and Thomas Wynn's recent translation finally provides the English reader with a punctilious critical edition; see their The 120 Days of Sodom (London: Penguin, 2016). Throughout this introduction, I have drawn on the following biographies of Sade: Francine du Plessix Gray, At Home with the Marquis de Sade: A Life (New York: Penguin, 1998); Ronald Hayman, Marquis de Sade: The Genius of Passion [1978] (London: Tauris Park, 2003); Maurice Lever, Sade: A Biography, trans. Arthur Goldhammer (San Diego: Harvest, 1994); and 
Neil Schaeffer, The Marquis de Sade: A Life (New York: Alfred A. Knopf, 1999). Where I have relied more heavily on any one of these, this will be indicated in the notes.

4 By officially classing the manuscript as a trésor national, the French Ministry of Culture blocked the auction of the manuscript, barred its exportation, and made Sade's infamous work part of the French patrimony. See the Ministry's press release of 19 December 2017, "Classement en tant que Trésors nationaux, d'un manuscript du Marquis de Sade et d'un ensemble d'écrits d'André Breton." The press release describes the manuscript and its value in these terms: "the handwritten manuscript of Donation-Alphonse-François de SADE, Les 120 Journées de Sodome, ou L'école du libertinage, paper scroll $11.3 \mathrm{~cm}$ wide and 1.12 long [sic for 12.10 metres long], 1785. This manuscript, notable for its peculiar format, a function of the conditions of its creation in a cell at the time of the incarceration of the Marquis de Sade in the Bastille, its considerably turbulent journey, its inflammatory reputation, and its influence on a number of twentieth-century French writers, is of major importance in Sade's oeuvre, insofar as it is his first veritable work, simultaneously the most radical and the most monumental, in spite of being unfinished" (my translation).

5 Available in English as The Misfortunes of Virtue and Other Tales, trans. David Coward (Oxford: Oxford University Press, 1992).

6 Justine, or the Misfortunes of Virtue, trans. John Phillips (Oxford: Oxford University Press, 2012). Like Les 120 journées de Sodome, this work was previously only available in English in a 1965 translation by Seaver and Wainhouse; see Justine, Philosophy in the Bedroom, and Other Writings (New York: Grove Press, 1965). The English titles of the first version of the Justine tale and the considerably longer published version of 1791 both include the word "misfortunes"; the French titles, however, are slightly different, with the earlier using infortunes [misfortunes] and the later malheurs [misfortunes, adversities, woes]. All three versions in French are collected in vol. 2 of Sade, Euvres, ed. Michel Delon (Paris: Gallimard, 1995). La Nouvelle Justine has never been translated into English.

7 L'Histoire de Juliette will be found in vol. 3 of Sade, Euvres, ed. Michel Delon (Paris: Gallimard, 1998). An English version exists as Juliette, trans. Austryn Wainhouse (New York: Grove Press, 1968).

8 Alice M. Laborde provides a useful account, with accompanying documentation, of Sade's lineage in her Généalogie et patrimoine du marquis de Sade, vol. 1 of Correspondances $d u$ marquis de Sade et des ses proches enrichies de documents, notes et commentaires (Geneva: Slatkine, 1991).

9 See Pierre Chessex, "Grand Tour," in Michel Delon, ed., Encyclopedia of the Enlightenment, trans. Gwen Wells (New York: Routledge, 2013), 622-5.

10 According to the travel recommendations of Jérôme Richard, one of Sade's principal guides (see infra), in his Description historique et critique de l'Italie (Dijon and Paris, 1766), 1:cxix.

11 See the introduction to Francesco Petrarch, Petrarch's Lyric Poems: The "Rime sparse" and Other Lyrics, trans. and ed. by Robert M. Durling (Cambridge, MA: Harvard University Press, 1976), 4-7.

12 For an extended account of the affaire d'Arcueil, Sade's depiction in the press as a human vivisector, and his subsequent literary responses to these characterizations, see James A. Steintrager, Cruel Delight: Enlightenment Culture and the Inhuman (Bloomington: Indiana University Press, 2004), 87-145.

13 For the blow-by-blow of the affaire de Marseilles, I have mainly relied on Maurice Lever's account in Sade: A Biography (195-216), albeit with the understanding that details come from perspectival testimony and that the author's access and omniscience are informed constructs. 
14 Cited in Lever, Sade: A Biography, 195.

15 Ibid.

16 See Alice M. Laborde, ed., Le procès en cassation d'Aix-en-Provence, vol. 12 of Correspondances du marquis de Sade et de ses proches enrichies de documents, notes et commentaires (Geneva: Slatkine, 1998), 19.

17 Sade had evidently seduced his sister-in-law, who had taken up residence in La Coste, prior to the journey. That Anne-Prospère de Launay travelled with Sade to Italy has long been asserted by his biographers, including the first important one, Gilbert Lely. See Lely's The Marquis de Sade: A Biography, trans. Alec Brown (New York: Grove Press, 1962), 131; originally published in French in two volumes, 1952 and 1957. Lely's evidence came from assertions in correspondence that were considerably less conclusive than his account would suggest, as Alice Laborde points out in Le procès en cassation d'Aix-en-Provence (40). The current biographical consensus is that, although Anne-Prospère was not in Sade's company when he was arrested in Chambéry, and while Sade had picked up another female companion on his travels whose identity remains unknown, his sister-in-law did accompany him initially, and she returned to France without him by early October of 1772. See Lever, Sade, 213-16; Schaeffer, Marquis de Sade, 141.

18 As reported in Laborde, Le procès en cassation d'Aix-en-Provence, 69.

19 Chorier's spurious attribution in his title was to Luisa Sigea de Velasco (1522-1560), born in the province of Toledo, a Spanish humanist and woman of letters. Sotades was a third-century BCE Greek poet of obscene verse, thus the adjective "sotadical." As for Vénus dans le cloitre, ou La Religieuse en chemise, to give the full title, it is sometimes attributed to abbé Jean Barrin (1640-1718), cantor at Nantes Cathedral.

On these first-wave books of obscene libertinism, see Lynn Hunt, "Introduction: Obscenity and the Origins of Modernity, 1500-1800," in Lynn Hunt, ed., The Invention of Pornography: Obscenity and the Origins of Modernity, 1500-1800 (New York: Zone, 1996), 27-31. On L'École de filles in particular, see Joan DeJean, The Reinvention of Obscenity: Sex, Lies, and Tabloids in Early Modern France (Chicago: University of Chicago Press, 2002), 56-83.

20 In Bradford K. Mudge, ed., When Flesh Becomes Word: An Anthology of Early EighteenthCentury Libertine Literature (Oxford: Oxford University Press, 2004), 199. Mudge's anthology includes translations of both Venus dans le cloitre as Venus in the Cloister: or, The Nun in her Smock (1725, 145-232), and Chorier's so-called satire, severely abridged, as A Dialogue Between a Married Lady and a Maid (1740, 235-56).

21 See Schaeffer, Marquis de Sade, 61. For an in-depth account of the erotics of flagellation in early modern Europe, including libertine literature, see Niklaus Largier, In Praise of the Whip: The Cultural History of Arousal, trans. Graham Harman (New York: Zone, 2007), 221-332.

22 Sade, Euvres, ed. Michel Delon (Paris: Gallimard, 1998), 3:685.

23 Sade's correspondence with Dr Mesny continued well after his return from Italy and into his imprisonment. He complains in a letter to his wife, dated 1 June 1777, that she has "ridiculously" taken a month to get a letter from Mesny to him; in a letter dated 9 June, he then thanks her for "the letters from Italy that you have had passed along to me." See Sade, Lettres et mélanges littéraires écrits à Vincennes et à la Bastille, ed. Georges Daumas and Gilbert Lely (Paris: Borderie, 1980), 1:56. The Italian project was obviously still very much on Sade's mind at this point.

24 On this character, see Jean-Claude Hauc, Ange Goudar: Un aventurier des Lumières (Paris: Honoré Champion, 2004), including discussion of the author's relationship with Sade in Florence (143-5). 
25 Casanova provided an account of the exploit in his Histoire de ma fuite des prisons de la République de Venise qu'on appelle les Plombs [Story of my escape from the prison of the Republic of Venice known as the Leads] (Leipzig, 1787).

26 See Hauc, Ange Goudar, 138-40.

27 Goudar's literary output was truly immense. For an effort to track it, see Francis L. Mars, "Ange Goudar, cet inconnu (1708-1791): Essai bio-bibliographique sur un aventurier polygraphe du XVIII ${ }^{\mathrm{e}}$ siècle," in Casanova Gleanings 9 (1966): 1-65. On the question of the authorship of Sarah Goudar's purported works, see Hauc, Ange Goudar, 136-7.

28 Maurice Lever, basing his view on mentions of Sarah in Sade's correspondence with Dr Mesny, states that the affair took place (Sade, 263-4). More circumspect, Neil Schaeffer asserts a distinct possibility rather than a fact (Marquis de Sade, 201 and 528n12).

29 On the shift in tourism in the 1770s from Florence and Venice to Rome, Naples, and further south, see Chessex, "Grand Tour," 625. On the importance of excavations in the vicinity of Naples in establishing the kingdom as a new centre for the appreciation of antique art, see Francis Haskell and Nicholas Penny, Taste and the Antique: The Lure of Classical Sculpture 1500-1900 (New Haven: Yale University Press, 1981), 74-8.

30 See Hayman, Marquis de Sade, 98.

31 Sade also owned a copy of Richard Lassels, Voyage of Italy, or a Compleat Journey through Italy (1670) in French translation as Voyage d'Italie, contenant les mœurs du peuple, la description des villes, \& tout ce qu'il y a de beau \& de curieux, 2 vols. (Paris, 1682). This was a seminal work of the grand tour, although Sade never mentions the author or the work in the manuscript. See Alice M. Laborde, La bibliothèque du marquis de Sade au château de La Coste (en 1776) (Geneva: Slatkine, 1991), 77.

32 The original English title was A Tour through Several Parts of Europe and the East; Especially the Following Places: Bologne, Paris and Its Environs, Nemours and Lyons, Avignon, Aix in Provence, Marseilles, Toulon, Genoa, Vicenza, Venice, Rome, Naples, Leghorn and Pisa, Florence, Bologna, Crete, Candia, and Other Places; In a Series of Letters by a Distinguished Gentleman Containing the Writer's Observations on the Productions of Nature, the Monuments of Art and the Manners of the Inhabitants, 2 vols. (London, 1760). The first edition was apparently published in 1750. The attribution to Dr Maihows seems to first appear in the bibliographer Jacques-Charles Brunet's Manuel de libraire et de l'amateur de livres (Paris: Brunet/ Leblanc, 1810), 3:232; and specifically with reference to Puisieux's translation. A laconic entry and cross reference in Antoine-Alexandre Barbier's Dictionnaire des ouvrages anonymes et pseudonymes, 2nd ed. (Paris: Barrois l'Aîné, 1822-1827), implies that this is a corruption of Matthews, although who the latter might be remains equally uncertain (4:382 and 4:393).

33 The print appeared in Giovanni Battista Piranesi's Diverse maniere d'adornare i cammini ed ogni altra parte degli edifizi desunte dell'architettura Egizia, Etrusca, e Greca con un Ragionamento Apologetico in defesa dell'Architettura Egizia, e Toscana [Various ways of adorning chimneys and all other parts of buildings taken from Egyptian, Etruscan, and Greek architecture, with an apologia in defence of Egyptian and Tuscan architecture] (Rome, 1769). On Piranesi and his reception of Chaupy's work, see Bernard D. Frischer, "Ramsay's 'Enquiry': Text and Context," in Bernhard D. Frischer and Iain Gordon Brown, eds., Allan Ramsay and the Search for Horace's Villa (Abingdon: Routledge, 2018), 85-7.

34 Sade, Correspondance. 1759-1814, vol. 12 of Euvres complètes du Marquis de Sade, ed. Gilbert Lely (Paris: Au Cercle du livre précieux, 1967), 79; hereafter Sade, Euvres complètes.

35 Ibid. For his part, Richard reasonably claimed that to make the most of your tour, you ought to learn Italian: you can ask for explanations, enjoy the pleasures of conversation, will have access 
to the latest news, and you will not feel like an "automaton" at social gatherings (Description historique et critique, 1:cx). He does remark that French is widely spoken in Europe, including Italy, but that most people you encounter will not speak it unless forced to do so. Dialects can be a problem on occasion, but usually not much of one, as "the Italian people everywhere generally understand pure and correct Italian" (1:cxiii).

36 Richard, Description historique et critique, unpaginated foreword.

37 Ibid., 1:xi.

38 Ibid.

39 On the recognition that philosophe had taken on a partisan signification by the 1750 s, which is confirmed by Charles Palissot de Montenoy's satirical and highly successful comedy Les Philosophes in 1760, and that philosophie was now a contested term, see Derek Beales, Enlightenment and Reform in Eighteenth-Century Europe (London: I.B. Tauris, 2005), 60-3. The most useful account of the development of partisan philosophie and its relation to the historical abstraction "Enlightenment" is, in my view, Hans Ulrich Gumbrecht, "Who Were the Philosophes?" in his Making Sense in Life and Literature, trans. Glen Burns (Minneapolis: University of Minnesota Press, 1992), 133-77.

40 See Richard H. Popkin, The History of Scepticism: From Savonarola to Bayle (New York: Oxford University Press, 2003), 283-302.

41 Lucian's account of Christians in The Passing of Peregrinus says nothing about their prognostications about the empire but rather emphasizes their ridiculous beliefs and gullibility. The following is from Lucian, trans. A.M. Harmon (Cambridge, MA: Harvard University Press, 1936):

The poor wretches have convinced themselves, first and foremost, that they are going to be immortal and live for all time, in consequence of which they despise death and even willingly give themselves into custody, most of them. Furthermore, their first lawgiver persuaded them that they are all brothers of one another after they have transgressed once for all by denying the Greek gods and by worshipping that crucified sophist himself and living under his laws. Therefore they despise all things indiscriminately and consider them common property. So if any charlatan and trickster, able to profit by occasions, comes among them, he quickly acquires sudden wealth by imposing upon simple folk. (5:15)

42 René Aubert de Vertot, Histoire des révolutions arrivées dans le gouvernement de la république romaine, 3rd ed. (Paris, 1727), 1:28-9. Sade's argument, which is Nietzschean avant la lettre, is that only when Christianity and its priestly hypocrisies become insinuated in Rome and eventually Europe as a whole do matters become almost irreversibly untenable and require something like a superman to overcome them - or, in Sade's case, a superwoman in the form of his Juliette. Again, these were views Sade largely shared with other spokesmen of radical philosophie, although he made quite different literary inferences from them.

43 See "An Answer to the Question: 'What Is Enlightenment?" in Immanuel Kant, Political Writings, ed. Hans Reiss and trans. H.B. Nisbet (Cambridge: Cambridge University Press, 1991), 54-60.

44 See Robert Darnton, The Forbidden Best-Sellers of Pre-Revolutionary France (New York: W.W. Norton, 1995), 86-114; and Margaret C. Jacob, "The Materialist World of Pornography," in Hunt, ed., Invention of Pornography, 157-202.

45 See Jean-Baptiste de Boyer, Marquis d'Argens, Lettres juives, ou Corréspondence philosophique, historique, et critique (Amsterdam, 1736), 1:79.

46 As Derek Beales remarks, in his Enlightenment and Reform, the "philosophes had claimed Joseph for themselves since the 1760s" (74). Sade's view of Joseph is entirely in tune with his 
attempt to cast himself as a member of the philosophical party, even if the relationship between the Holy Roman Emperor and philosophie as a partisan movement is complex (see Beales, 74-9).

47 Laborde, Bibliothèque du marquis de Sade, 97.

48 Alice M. Laborde, noting Sade's praise for the enlightened ruler of Florence, maintains that the fugitive met the grand duke; the manuscript of Sade's Italian journey provides no evidence of direct contact with Leopold, nor have I seen correspondence that would confirm this (ibid., 75).

49 Pierre Bourdieu, The Logic of Practice, trans. Richard Nice (Stanford: Stanford University Press, 1990), 53.

50 Richard, Description historique et critique, 1:xxxv.

51 On climate in relation to racial difference in eighteenth-century Europe, see the following: Roxann Wheeler, The Complexion of Race: Categories of Difference in Eighteenth-Century British Culture (Philadelphia: University of Pennsylvania Press, 2000), 1-48; David Bindman, Ape to Apollo: Aesthetics and the Idea of Race in the 18th Century (Ithaca: Cornell University Press, 2002), 58-70; and Andrew S. Curran, The Anatomy of Blackness: Science and Slavery in an Age of Enlightenment (Baltimore: Johns Hopkins University Press, 2011), 83-5 and passim.

52 Richard, Description historique et critique, 1:cviii.

53 Ibid., 1:xxxv.

54 Ibid., 1:xxxvi.

55 Ibid., 1:xli.

56 For a general history of policing in France, see Robert Muchembled, La Société police. Politique et politesse en France du $X V^{e}$ au $X X^{e}$ siècle (Paris: Seuil, 1998). On eighteenth-century Paris in particular, see Alan Williams, The Police of Paris, 1718-1789 (Baton Rouge: Louisiana State University Press, 1979). Michel Foucault also deals with the rise of policing extensively in Security, Territory, Population: Lectures at the Collège de France, 1977-1978, trans. Graham Burchell (New York: Picador, 2007), esp. 311-61. Foucault's overarching arguments about bio-power and particularly the roles of surveillance and disciplining agencies in modern societies that he made in the 1970s resonate with the development of this apparatus in seventeenthand eighteenth-century France.

57 On Montesquieu and the representation of harems as political and cultural critique, see Elizabeth Heckendorn Cook, Epistolary Bodies: Gender and Genre in the Eighteenth-Century Republic of Letters (Stanford: Stanford University Press, 1996), 30-70; Ruth Bernard Yeazell, Harems of the Mind: Passages of Western Art and Literature (New Haven: Yale University Press, 2000), 66-73; and James A. Steintrager, The Autonomy of Pleasure: Libertines, License, and Sexual Revolution (New York: Columbia University Press, 2016), 85-92.

58 Nicolas de La Mare, Traité de la Police, 2nd ed. (Amsterdam, 1729), 1:447.

59 Alice M. Laborde, ed., Le marquis de Sade et son père, vol. 3 of Correspondances du marquis de Sade et de ses proches enrichies de documents, notes et commentaires (Geneva: Slatkine, 1991), 267-8. For Sade's passionate and importunate love letters to the actress, who seems to have initially rebuffed his advances, see ibid., 268-75. For biographical accounts of his affair with Colet, whose name Marais spells Colette, see Gray, At Home with the Marquis de Sade, 71-4; Lever, Sade, 126-30; Schaeffer, Marquis de Sade, 71-5.

60 Laborde, Le marquis de Sade et son père, 268.

61 For a lively early twentieth-century account of La Brissault, her husband, and their business, see Gaston Capon, Les maisons closes au XVIII ${ }^{e}$ siècle (Paris: H. Daragon, 1903), 162-71. The author notes that La Brissault kept two brothels: one on the outskirts of town near the Barrière Blanche; another in Paris proper, initially on the rue Tire-Boudin and later on the rue Française, 
conveniently located just across from the Comédie-Italienne or Italian Comic Opera (162). The rue Tire-Boudin (literally "Sausage-Yank Street") was long associated with prostitution. This was also a slightly more decorous appellation than the original rue Tire-Vit ("Prick-Yank Street"). It is now called rue Marie-Stuart, and urban legend had it that the initial euphemistic change came about when Mary Stuart, briefly wife of François II and queen consort of France, innocently asked the name of the street and, out of decency, a substitution was made. See Germain-François Poullain de Saint-Foix, Essais historiques sur Paris (London, 1767), 1:248.

62 Laborde, Le marquis de Sade et son père, 268.

63 A modern edition of Nicolas Edme Rétif de la Bretonne's Le Pornographe is included in Cuvres érotiques de Restif de la Bretonne, vol. 2 of L'Enfer de la Bibliothèque Nationale (Paris: Fayard, 1985).

64 On Rétif's project in relation to other such works of the organization and control of prostitution written in eighteenth-century France, see Pamela Cheek, Sexual Antipodes: Enlightenment Globalization and the Placing of Sex (Stanford: Stanford University Press, 2003), 104-20; Steintrager, Autonomy of Pleasure, 100-27; and Amy S. Wyngaard, Bad Books: Rétif de la Bretonne, Sexuality, and Pornography (Newark: University of Delaware Press, 2013), 47-76.

65 Translated as Carlo Antonio Pilati, Projet d'une Réforme à faire en Italie, ou Moyens de corriger les abus les plus dangereux, \& de réformer les Loix les plus pernicieuses, établies en Italie (Amsterdam, 1769).

66 My slightly modified rendering of what Bette Talvacchia has as "I want it in my rear," in her excellent analysis of Aretino and more broadly the postures tradition in art history and literature, in Taking Positions: On the Erotic in Renaissance Culture (Princeton: Princeton University Press, 1999), 213. Talvacchia's book provides all of the extant sonnets in the original Italian, translations, and the woodcut illustrations.

67 Ibid.

68 Antonio Vignali, La Cazzaria: The Book of the Prick, ed. and trans. by Ian Frederick Moulton (London: Routledge, 2003), 88. For a modern translation of I Ragionamenti, see Pietro Aretino, Aretino's Dialogues, trans. Raymond Rosenthal (Toronto: University of Toronto Press, 2005).

69 See Guido Ruggiero, Machiavelli in Love: Self, Sex, and Society in the Italian Renaissance (Baltimore: Johns Hopkins University Press, 2010), 24-8.

70 Sade's source and reference is Benedetto Varchi, Histoire des Révolutions de Florence, sous les Médicis, trans. Jean-Baptiste Requier (Paris, 1764), 1:213. For a recent account of Florentine sodomy laws and their inconsistent enforcement by the Office of the Night, see Michael Rocke, Forbidden Friendship: Homosexuality and Male Culture in Renaissance Florence (New York: Oxford University Press, 1996), esp. 228-35.

71 On Gian Gastone and the grand tour, see G.S. Rousseau, "The Pursuit of Homosexuality in the Eighteenth Century: 'Utterly Confused Category' and/or Rich Repository,' in Robert P. Maccubbin, ed., 'Tis Nature's Fault: Unauthorized Sexuality during the Enlightenment (Cambridge: Cambridge University Press, 1987), 159.

72 Baptista Spagnuoli Mantuanus, Prima pars operum in qua sunt Alphonsus, etc. (n.p., 1507), n.p.

73 Jean-Jacques Rousseau, The Basic Political Writings, trans. Donald A. Cress, introduction and annotation by David Wootton (Indianapolis: Hackett, 2011), 64.

74 Composed over many years and completed around 1780, the work was published posthumously in 1796. For a recent translation of this work, see Denis Diderot, The Nun, trans. Russell Goulbourne (Oxford: Oxford University Press, 2005).

75 Sade, Euvres, 3:686. 
76 Hans Blumenberg, The Legitimacy of the Modern Age, trans. Robert M. Wallace (Cambridge, MA: MIT Press, 1983). See also Barbara M. Benedict, Curiosity: A Cultural History of Early Modern Inquiry (Chicago: University of Chicago Press, 2001). For an analysis of how the rehabilitation of curiosity had a complex relation to empiricism and animal experimentation, as well as to Sade's biography and writings, see Steintrager, Cruel Delight, 37-83 and 115-24.

77 The term cabinet de curiosités was widely in use at the time of Sade's journey, as was the rubric "natural history." See, e.g., the title of Johann Vollrath Bacmeister's account of an important Russian collection: Essai sur la Bibliothèque et le Cabinet de curiosités et d'histoire naturelle de l'Académie des Sciences à Saint Petersbourg [Essay on the library and the cabinet of curiosities and of natural history of the Academy of Sciences in St Petersburg] (n.p. [St Petersburg], 1776). An example of Enlightenment cosmopolitanism, Bacmeister was a German, resident in St Petersburg and employed at the Russian imperial Academy of Arts and Sciences (founded in 1724), and here publishing in French (as was the official bulletin of the Academy).

78 On the development of these collections, see Paula Findlen, "Inventing Nature: Commerce, Art, and Science in the Early Modern Cabinets of Curiosity," in Pamela H. Smith and Paula Findlen, eds., Merchants and Marvels: Commerce, Science, and Art in Early Modern Europe (Abingdon: Routledge, 2002), 297-323.

79 Sade recommends Mesny's cabinet of curiosities to travellers in the chapter on Florence, and he is not alone in mentioning this collection. Antoine Joseph Dézallier d'Argenville in his listing of various cabinets that include interesting specimens of shells, notes in Florence the collection of "M. Mesny, a French national," in his La Conchyliologie, ou Histoire naturelle des coquilles (Paris, 1780), 1:839. Johann Jakob Ferber, more interested in minerals than shells, remarks his regret at missing the cabinet of Bartholomée Mesny when he passed through Florence, as the Frenchman was visiting his homeland; see Lettres sur la minéralogie et sur divers autres objects de l'histoire naturelle de l'Italie, trans. Mr le B. de Dietrich (Strasbourg, 1776), 395. Joseph Jérôme Le François de Lalande also notes, in vol. 2 of his Voyage d'un François en Italie, fait dans les années $1765 \& 1766$ (Yverdon, 1769), that "one of the lovely collections of natural history to be found in Florence is that of Mr Mesny, skilled physician, Director of the Hospitals of Tuscany, as well as of the Pitti Palace's pharmacy, [known as the] Speziaria." $\mathrm{He}$ adds that this "cabinet is put together intelligently and carefully" and that it contains "quite interesting specimens of natural history." He concludes that "the professor is a lovable man, with whom the curious will find all manner of satisfaction" (2:371).

80 We know from an undated letter, likely written between 1775 and 1777, to his solicitor Gaspard-François-Xavier Gaufridy that Sade planned such a cabinet. In the letter, he also mentions petrifactions that he had purchased on the cheap in Marseilles. See Sade, Lettres inédites et documents, ed. Jean-Louis Debauve (Paris: Pauvert, 1990), 188.

81 Pliny the Elder, in his Natural History, Volume 1, books 1-2, trans. H. Rackham (Cambridge, MA: Cambridge University Press, 1938), mentions "the lethal breaths either emitted from chasms or due to the mere formation of the ground, in some places fatal only to birds, as in the region of Soracte near Rome, in others to all living creatures except man, and sometimes to man also, as in the territory of Sinuessa and of Pozzuoli - the places called breathing holes, or by other people jaws of hell - ditches that exhale a deadly breath [ut in Sinuessano agro et Puteolano, quae spiracula vocant, alii Charonea, scrobes mortiferum spiritum exhalantes]" (338-9). There are notes on the grotto, including a description of the usual experiment, in a translation of this work that came out shortly before Sade's trip. See Pliny the Elder, Histoire naturelle de Pline (Paris, 1771), 1:418. 
82 See Alexandre de Rogissart et al., Les Délices de l'Italie, Qui contiennent une Description exacte du Pays, des principales Villes, de toutes les Antiquitez, \& de toutes les raretez, qui s'y trouvent (Leiden, 1709), 5:94-5.

83 The killing of the slaves and of the ass are mentioned in Rogissart (ibid., 5:95). Both incidents are also reported in an overview of the grotto and its powers in Alleon Dulac, Mélanges d'histoire naturelle (Lyon, 1765), 3:372-5.

84 See Anon., Histoire de l'Académie Royale des Sciences. Année MDCCXLV. Avec les Mémoires de Mathémathique \& de Physique, pour la même année (Paris, 1749), 16-17. On Taitbout de Marigny's identity and service, see Anne Mézin, Les consuls de France au siècle des lumières (1715-1792) (Paris: Ministère des affaires étrangères, 1980), 556-7.

85 An experimental apparatus compellingly studied in relation to seventeenth-century intellectual history in Steven Shapin and Simon Schaffer, Leviathan and the Air-Pump: Hobbes, Boyle, and the Experimental Life (Princeton: Princeton University Press, 2011). In the eighteenth century, the air pump remained an important part of the empiricist arsenal and was also used for pedagogical purposes. Joseph Wright of Derby's celebrated painting Experiment on a Bird in the Air Pump (1768) shows the apparatus being demonstrated before a group of amateurs.

86 Anon., Histoire de l'Académie Royale des Sciences. Année MDCCL. Avec les Mémoires de Mathémathique \& de Physique, pour la même année (Paris, 1754), 77. The citation above is from a first-hand account by Jean-Antoine Nollet, priest and pioneering researcher in the field of electricity, given in his "Suite des expériences et observations faits en differens endroits de l'Italie," in the Mémoires de Mathémathique \& de Physique part of the volume (54-106), which has separate pagination from the Histoire. The first set of abbé Nollet's observations on Italy had been published the previous year.

87 See Anon., Histoire de l'Académie Royale des Sciences. Année MDCCLXX. Avec les Mémoires de Mathémathique \& de Physique, pour la même année (Paris, 1773), 67.

88 The "Royal Academy of Projectors" in Lagado, the capital of the imaginary island of Balnibari, is full of deluded experimentalists who misguidedly impose rational solutions on social problems and attempt ridiculous scientific procedures such as "extracting Sun-Beams out of Cucumbers." See Jonathan Swift, The Essential Writings of Jonathan Swift, ed. Claude Rawson and Ian Higgins (New York: W.W. Norton, 2010), 426. Along with the Royal Philosophical Society, Swift is taking aim at what he deemed provincial imitations such as the Dublin Philosophical Society.

89 Pliny the Younger, The Letters of Pliny, Volume I: Books 1-7, trans. Betty Radice (Cambridge, MA: Harvard University Press, 1969), 428-9.

90 The additional material in the expanded edition had initially been published in separate pamphlets as Supplemento alla storia del Vesuvio [Supplement to the history of Vesuvius] (Naples, 1761), which covered the 1760 eruption, and as Incendio del Vesuvio accaduto li 19 d'ottobre del 1767 [Eruption of Vesuvius that occurred on 19 October 1767] (Naples, 1767). For a recent account of seventeenth- and eighteenth-century Vesuvius watchers, including Della Torre, see Sean Cocco, Watching Vesuvius: A History of Science and Culture in Early Modern Italy (Chicago: University of Chicago Press, 2013).

91 William Hamilton, Observations on Mount Vesuvius, Mount Etna, and Other Volcanoes (London, 1772), 7-8.

92 Ibid., 8.

93 Ibid., 27.

94 Ibid., 11.

95 See Laborde, Bibliothèque du marquis de Sade, where the work is notable in its absence. 
96 Francis Hutcheson, An Inquiry into the Original of Our Ideas of Beauty and Virtue, ed. Wolfgang Leidhold (Indianapolis: Liberty Fund, 2004), 28.

97 A much-discussed notion in aesthetic, literary, and intellectual history, the widespread and increasingly intense early modern interest in the sublime can be traced to Nicolas BoileauDespréaux's translation and publication of (pseudo-) Longinus's rhetorical treatise on the topic as the Traité du sublime ou du merveilleux dans le discours (Paris, 1674).

98 It was Kant who above all insisted on and theorized the sublime as the blockage of the powers of imagination. See Critique of the Power of Judgment, trans. Paul Guyer and Eric Matthews (Cambridge: Cambridge University Press, 2000), 128-48.

99 Anon. [Claude Boutet?], Traité de la peinture en mignature, pour apprendre aisément à peindre sans maître (The Hague, 1708), 241. This is a new and augmented edition, and covers painting more generally, in addition to the focus on miniature. The dedication is signed "C.B.," although the attribution to Claude Boutet, about whom little is known, is debatable.

100 Ibid.

101 This arrival date is confirmed in a letter from Vien himself. See Anatole de Montaiglon and Jules Guiffrey, eds., Correspondance des directeurs de l'Académie de France à Rome (Paris: Jean Schemit, 1904), 13:156. Between Natoire and Vien, Noël Hallé (1711-1781) briefly served as director, reporting to his superiors in France that he had left France on 8 June, had belatedly arrived at seven in the morning on $3 \mathrm{July}$, and that the accommodations he had inherited from the departing director were in shambolic condition (13:93).

102 Anon., Traité de la peinture en mignature, 11.

103 As Wendy Olmsted, in her Rhetoric: An Historical Introduction (Malden, MA: Blackwell, 2006), defines the classical notion of decorum: "the appropriateness of style to the matter and purpose at hand. This decorum was not fixed; rather it worked dynamically through the art of the speaker" (26).

104 Anon., Traité de la peinture en mignature, 12.

105 Charles Le Brun initially gave his account of how to draw the passions in a lecture in 1668. The work was first published as Conférence de M. Le Brun, premier peintre du roi, chancelier et directeur de l'Académie de Peinture et de Sculpture, sur l'expression générale et particulière, enrichie de figures gravées par B. Picart (Amsterdam and Paris, 1698). It is better known under the title Méthode pour apprendre à dessiner les passions, which first appeared as the work's title in an Amsterdam imprint from 1702.

106 René Dubos, Réflexions critiques sur la poésie et sur la peinture (Paris, 1719), 1:12.

107 See Herbert Dieckmann, "Die Abscheuliche und Schreckliche in der Kunsttheorie des 18. Jahrhunderts," in Hans Robert Jauß, ed., Die nicht mehr schönen Künste: Grenzphänomene des Ästhetischen (Munich: Wilhelm Fink Verlag, 1968), 271-317; Carsten Zelle, “Angenehmes Grauen": Literaturhistorische Beiträge zur Ästhetik des Schrecklichen im achtzehnten Jahrhundert (Hamburg: Felix Meiner Verlag, 1987).

108 Aristotle, Aristotle's Theory of Poetry and Fine Art, trans. and ed. by S.H. Butcher (New York: Dover, 1951), 95. The importance of verisimilitude was elaborated in Aristotle's early modern reception by, among others: Julius Caesar Scaliger in his Poetices libri septem (1561) and François Hédelin, abbé d'Aubignac, who in his Pratique du théatre dedicates a chapter to the topic (1657). Julius Caesar Scaliger or Scaligerus was the Latinized form of Giulio Cesare della Scala, who was Italian by birth but spent the bulk of his career in Agen in southwest France.

109 Marc-Antoine Laugier, Essai sur l'architecture. Nouvelle edition, revue, corrigée, \& augmentée; avec un dictionnaire des termes (Paris, 1755), 16-17. 
110 Françoise Fichet discusses and provides excerpts from this debate in her La théorie architecturale à l'âge Classique: Essai d'anthologie critique (Liège: Pierre Mardaga, 1995), 281-92 and 333-46. Prior to the exchange in the Mémoires de Trévoux, Jean-Louis de Cordemoy had presented some gentle criticisms of Saint Peter's in his recently published Nouveau traité de toute l'architecture, utile aux entrepreneurs, aux ouvriers, et à ceux qui font bâtir [New treatise on the whole of architecture, useful for contractors, workers, and those responsible for building] (Paris, 1706), see 170-87.

111 From the French translation of Francesco Milizia's work, L'art de voir dans les beaux-arts [The art of seeing the fine arts] (Paris, 1798), 224. The title of the original Italian work is Dell'arte di vedere nelle belle arti del disegno secondo i principii di Sulzer e di Mengs [On the art of seeing in fine arts of drawing based on the principles of Sulzer and Mengs] (Venice, 1781). Kant, in his Critique of the Power of Judgment, was still referring to this debate in critical aesthetics, where he considers "the bewilderment or sort of embarrassment that is said to seize the spectator on first entering St Peter's in Rome": "For here there is a feeling of the inadequacy of his imagination for presenting the ideas of a whole, in which the imagination reaches its maximum and, in the effort to extend it, sinks back into itself, but is thereby transported into an emotionally moving satisfaction" (136).

112 See Giorgio Vasari, Lives of the Artists, trans. George Bull (New York: Penguin, 1987), $1: 25-56$.

113 Rousseau, Basic Political Writings, 6.

114 Richard, Description historique et critique, 1:1xxi.

115 Ibid.

116 Ibid., $1: \mathrm{lxx}$.

117 Ibid., 1:lxix.

118 Ibid., 1:xcii and 1:xcvi.

119 David Hume, e.g., tries to account for historical, national, and other variations in attributions of beauty in his essay "Of the Standard of Taste," in Essays: Moral, Political, and Literary, ed. Eugene F. Miller (Indianapolis: Liberty Fund, 1987), 171-86. The temporalizing position was most carefully elaborated in Johann Gottfried Herder's writings and aesthetic re-evaluations of the 1770s, most importantly in the initial sections of Von Deutscher Art und Kunst [On German Style and Art]. See also the following: German Literary and Aesthetic Criticism: The Romantic Ironists and Goethe, ed. Kathleen Wheeler (Cambridge: Cambridge University Press, 1984), 5; Stephen Gaukroger, "The Role of Aesthetics in Herder's Anthropology," in Anik Waldow and Nigel DeSouza, eds., Herder: Philosophy and Anthropology (Oxford: Oxford University Press, 2017), 100-3.

120 On the libertine adoption and use of caprice as a (non-)principle that justifies any manner of sexual pleasure, see Steintrager, Autonomy of Pleasure, 246-59.

121 Solid general works on sensibility, with a bias to Britain, include the following: Janet Todd, Sensibility: An Introduction (London: Methuen, 1986); G.J. Barker-Benfield, The Culture of Sensibility (Chicago: University of Chicago Press, 1992); and Ann Jessie van Sant, EighteenthCentury Sensibility and the Novel (Cambridge: Cambridge University Press, 2004). For the French context more specifically, see Anne Vila, Enlightenment and Pathology: Sensibility in the Literature and Medicine of Eighteenth-Century France (Baltimore: Johns Hopkins University Press, 1997). Both van Sant and Vila situate Sade in relation to the discourse of sensibility, as does Steintrager, Cruel Delight (see esp. 95-114).

122 The relation between Sade's novels and sentimental literature has long been remarked; for a notable early example, see R.F. Brissenden, Virtue in Distress: Studies in the Novel of Sentiment from Richardson to Sade (London: Macmillan, 1974). 
123 Denis Diderot, Euvres esthétiques, ed. Paul Vernière (Paris: Bordas, 1988), 739.

124 Ibid., 696.

125 The notion of aesthetic interest is perhaps most easily grasped through its negation in Kant's aesthetic theory, where proper judgments of beauty are deemed interesselos (disinterested or, more literally, interest-less). Kant thereby sought to remove from aesthetic judgment in the case of beauty any pathological - i.e., passionate and subjective - taint. If the satisfaction felt in a representation is linked to its possible existence, what we have is desire; we ought only to speak of beauty when an object triggers a sort of formal, empty, and harmonious play of the faculties of imagination and judgment, in which we may be said to have a disinterested interest insofar as such play is experienced as pleasing (see Kant's Critique of the Power of Judgment, 90-6). Kant obviously rejects eroticism with such assertions, and provides examples of what beauty-triggering objects tend to be either natural or utterly uncompelling and trivial, such as arabesques and the like - "designs à la grecque, foliage for borders or on wallpaper, etc." (114). Sade, for his part, intriguingly crosses the wires in the case of Duquesnoy: the boys who pose for him are reduced to arabesques, but the beauty of these forms turns out to be sexually attractive. As I have argued elsewhere, the fundamental contrast between Kant and at least later Sade - although we catch a glimpse already - is that one upholds disinterested interest and the other interested disinterest or what we might call the paradox of detached sensibility. See Steintrager, Cruel Delight, 143.

126 Diderot, Euvres esthétiques, 536. There is likely a glimpse here of Catullus's poem that begins: "Mourn, ye Graces and Loves, and all you whom the Graces love. My lady's sparrow is dead [passer mortuus est meae puellae, / passer deliciae meae puellae], whom she loved more than her very eyes." See Catullus and Tibullus, Catullus. Tibullus. Pervigilium Veneris, trans. F.W. Cornish, J.P. Postgate, and J.W. Mackail, revised by G.P. Goold (Cambridge, MA: Harvard University Press, 1988), 4-5.

127 Denis Diderot, Salon de 1765, ed. Else Marie Bukdahl and Annette Lorenceau (Paris: Hermann, 1984), 92. Little known or appreciated today, Lagrenée would succeed Vien as the director of the French Academy in Rome, serving from 1781 to 1787.

128 See Ludwig Wittgenstein, Philosophical Investigations, trans. G.E.M. Anscombe (Malden, MA: Blackwell, 2001), 4. On the longer history of the picturesque in France, especially with regard to verse, see Wil Munsters, La poétique du pittoresque en France de 1700 à 1830 (Geneva: Droz, 1991).

129 Uvedale Price, in An Essay on the Picturesque, as Compared with the Sublime and the Beautiful (London, 1794), writes: "A temple or palace of Grecian architecture in its perfect entire state, and its surface and colour smooth and even, either in painting or reality, is beautiful; in ruin it is picturesque. Observe the process by which time (the great author of such changes) converts a beautiful object into a picturesque one. First, by means of weather stains, partial incrustations, mosses, \&c. it at the same time takes off from the uniformity of its surface and of its colour; that is, gives it a degree of roughness, and variety of tint. Next, the various accidents of weather loosen the stones themselves; they tumble in irregular masses upon what was perhaps smooth turf or pavement, or nicely trimmed walks and shrubberies, now mixed and overgrown with wild plants and creepers, that crawl over and shoot among the fallen ruins" (46-9).

130 Diderot, Euvres esthétiques, 641.

131 Inferring from ruins to a politics of equality had been hinted at since at least Rousseau and would receive its fullest treatment in abolitionist and cosmopolitan meditations of Constantin François de Chassebœuf, comte de Volney's Les Ruines, ou Méditations sur les révolutions des empires (Paris, 1791). 
132 See Melissa Calaresu, "Looking for Virgil's Tomb: The End of the Grand Tour and the Cosmopolitan Ideal in Europe," in Jas Elsner and Joan Pau Rubiés, eds., Voyages and Visions: Towards a Cultural History of Travel (London: Reaktion Books, 1999), 138-61.

133 On Paestum, these works, and the Doric revival, see James Stevens Curl, Georgian Architecture (Newton Abbot: David and Charles, 2002), 74-6. For a recent scholarly account, see Giovanna Ceserani's Italy's Lost Greece: Magna Graecia and the Making of Modern Archaeology (Oxford: Oxford University Press, 2012).

134 In Grosley's account, the Neapolitan art student is vacationing in his hometown of Capaccio when he comes across the ruins of Paestum, at the time part of a plot being used by a tenant farmer for pasturing his animals. Inquiring locally about the ruins, he discovers that as long as anyone can remember, the land was uncultivated and abandoned until the tenant farmer set up there some twelve years ago. He had scavenged the site and unearthed enough valuable finds that he had been able to buy the land. After the student's report, interest grew and the site now attracts "crowds." See Pierre-Jean Grosley, Nouveaux Mémoires, ou Observations sur l'Italie (London, 1764), 3:87-9. Joseph Jérôme Le François de Lalande, citing Grosley, repeats the story almost verbatim in his Voyage d'un françois en Italie (Yverdon, 1770), 7:106-7.

135 See Giuseppe Antonini, La Lucania (Naples, 1745), 213-79.

136 Ibid., 218.

137 Having initially followed Grosley on the rediscovery of Paestum, Lalande would later modify his account, taking note of Antonini's discussion of the site and mentioning Soufflot and Marigny's visit in 1750, although still crediting the student for finding the site proper and its current celebrity. See Joseph Jérôme Le François de Lalande, Voyage en Italie, conténant l'Histoire \& les Anecdotes les plus singulières de l'Italie (Paris, 1786), 7:594-5. He would subsequently revise his account once more to place Soufflot and Marigny's visit in 1760, which, although incorrect, does make sense of the supposed sequence of rediscovery. See Joseph Jérôme Le François de Lalande, Voyage en Italie, conténant l'histoire \& les anecdotes les plus singulières de l'Italie \& sa description (Yverdon, 1788), 6:197.

138 See Vitruvius, Ten Books on Architecture, trans. Ingrid D. Rowland, commentary and illustrations by Thomas Noble Howe (Cambridge: Cambridge University Press, 1999), 55 (in book 4, chapter 1).

139 Laugier, Essai sur l'architecture, 87.

140 Charles de Brosses, Lettres sur l'état actuel de la ville souterraine d'Herculée, et sur les causes de son ensevelissement sous les ruines du Vésuve (Dijon, 1750), 60.

141 On these discoveries and the protectiveness and attitudes of Charles of Naples and his son Ferdinand, see Haskell and Penny, Taste and the Antique, 74-6.

142 Jérôme Charles Bellicard and Charles-Nicolas Cochin, Observations upon the antiquities of the town of Herculaneum, discovered at the foot of Mount Vesuvius: with some reflections on the painting and sculpture of the ancients: and a short description of the antiquities in the neighbourhood of Naples (London, 1754), iv. It appears that the English edition of this work was published the year before the French one.

143 Ibid., 58.

144 A detailed account of the cataloging of the excavations, including the earlier and unsatisfying work of Ottavio Antonio Bayardi in the 1750s and the publication history of Le Antichità di Ercolano Esposte, will be found in Carol C. Mattusch with Henry Lie, The Villa dei Papiri at Herculaneum: Life and Afterlife of a Sculpture Collection (Los Angeles: Getty Publications, 2005), 65-75. See also Claire R. Lyons and Marcia Reed, "The Visible and the Visual: Pompeii and Herculaneum in the Getty Research Collection," in Victoria C. Gardner Coates 
and Jon L. Seydl, eds., Antiquity Rediscovered: The Legacy of Pompeii and Herculaneum (Los Angeles: Getty Publications, 2007), 137-42; and Haskell and Penny, Taste and the Antique, $75-6$.

145 Johann Joachim Winckelmann, Sendschreiben von den Herculanischen Entdeckungen. An den Hochgebohrnen Herrn, Herrn Heinrich Reichsgrafen von Brühl (Dresden, 1762), 34. This work was soon after translated into French as Lettre de M. l'abbé Winckelmann, antiquaire de sa Sainteté, à Monsieru le comte de Brühl, chambellan du roi de Pologne, Électeur de Saxe, sur les découvertes d'Herculanum (Dresden, 1764).

146 Ibid.

147 Richard Payne Knight, An Account of the Remains of the Worship of Priapus, Lately Existing at Isernia, in the Kingdom of Naples: in Two Letters ... to which is added, A Discourse on the Worship of Priapus, and its Connexion with the mystic Theology of the Ancients (London, 1786), 27.

148 Ibid., 24-5.

149 Rousseau, Basic Political Writings, 9.

150 Martial, Toutes les Épigrammes de Martial en Latin et en François, avec de petites nottes, trans. Michel de Marolles (Paris, 1655), 1:n.p.

151 Ibid.

152 Martial, Epigrams. Book Two, ed., trans., and commentary by Craig A. Williams (Oxford: Oxford University Press, 2004), 108-9; original emphasis. I have drawn from Williams's illuminating commentary on this epigram (see 108-11).

153 Toutes les Épigrammes de Martial, 1:156.

154 Ibid., 157.

155 Martial, Epigrams. Book Two, 110.

156 Sade, Euvres, 3:623. Sade's citation renders lines from book 11, epigrams of Martial. The full epigram in D.R. Shacklton Baily's translation of Martial, Epigrams (Cambridge, MA: Harvard University, 1993) reads:

Catching me with a boy, wife, you upbraid me harshly and point out that you too have an arse. How often did Juno say the same to her wanton Thunderer! Nonetheless, he lies with a strapping Ganymede. The Tirynthian [i.e., Hercules] used to lay aside his bow and bend Hylas [his young male companion] over: do you think Megara [Theban princess and Hercules's wife] had no buttocks? Fugitive Daphne tormented Phoebus: the Oebalian [i.e., Spartan] boy bade those flames vanish. Though Briseis often lay with her back to Aeacus's son [i.e., Achilles, the grandson of Aeacus], his smooth friend was closer to him. So kindly don't give masculine names to your belongings, wife, and think of yourself as having two cunts. (3:39)

This epigram is not provided in its entirety in Latin in Toutes les Épigrammes de Martial, although its coarse concluding lines are; no French version is provided at all, with the comment that it is one of those epigrams that is "untranslatable" (morally, one supposes) (2:307). Sade's apparent source is, moreover, a translation of Chorier's Aloisiae Sigaeae, Toletanae, Satyra sotadica de arcanis Amoris et Veneris that was published either during or shortly after his voyage. Here, in a lesson on the classical tradition, we find the exact lines that our author provides in Juliette as part of a loose translation of the epigram that explains that Juno cannot always please Jupiter because, in spite of the options she can provide him, he is sometimes simply "tired of Womankind [las du Féminin]," from anon. [Nicolas Chorier], Nouvelle Traduction du Mursius, connu sous le nom d'Aloïsia, ou De l'Académie des Dames [Cythera [!], 1776], 2:23. 
157 On the authorship of L'École des filles, sometimes attributed to a certain Michel Millot, see DeJean, The Reinvention of Obscenity $(63-5,151-2 \mathrm{n} 9$, and 153-4n22).

158 A critical edition in French of this work is included in Sade, Euvres, vol. 3 (Paris: Gallimard, 1998). To my mind, the best English translation of this work remains Richard Seaver and Austryn Wainhouse in Sade, Justine, Philosophy in the Bedroom, and Other Writings (New York: Grove, 1965), although there is a more recent version: see Sade, Philosophy in the Boudoir, trans. Joachim Neugroschel (New York: Penguin, 2006).

159 See Laborde, Bibliothèque du marquis de Sade, 55.

160 See Lucian, Chattering Courtesans and Other Sardonic Sketches, trans. Keith Sidwell (London: Penguin, 2004), 157-89.

161 Aretino's Dialogues, 4.

162 See Romano Giulio, Marcantonio Raimondi, Pietro Aretino, and Count Jean-FrédéricMaximilien de Waldeck, I Modi: The Sixteen Pleasures. An Erotic Album of the Renaissance, trans., ed., and commentary by Lynne Lawner (Evanston: Northwestern University Press, 1988), 3 and 10-15; Talvacchia, Taking Positions, 71-84.

163 Ovid, The Art of Love and Other Poems, trans. J.H. Mozley and revised by G.P. Goold (Cambridge, MA: Harvard University Press, 1979), 172-3.

164 Aretino is also not so obliquely referring in this instance to the illustrations for which he had provided commentary in his Sonetti lussuriosi [Aretino's dialogues, 44].

165 On the relation of La Mettrie and licentious libertinism, see Darnton, Forbidden Best-Sellers, 95. Again, the general connection between materialist philosophy and libertinism is laid out in Margaret C. Jacobs, "The Materialist World of Pornography," in Hunt, Invention of Pornography, 157-202.

166 On the parodical elements of Sade's licentious works, including La Philosophie dans le boudoir and the faux pamphlet mentioned above, see Lucienne Frappier-Mazur, Writing the Orgy: Power and Parody in Sade, trans. Gillian C. Gill (Philadelphia: University of Pennsylvania Press, 1996).

167 Sade, Euvres, 2:555.

168 Ibid. On Guido Reni (1575-1542), Michelangelo, and the justification of human vivisection in Sade, see Steintrager, Cruel Delight, 92-5 and 131-45. On these topics in relation to the Italian project, see also Maurice Lever's introduction to Sade, Voyage d'Italie, 1:31-3.

169 Sade here echoes the opinion of abbé Jérôme Richard, likely his source on the story: "Among the paintings is a Christ nailed to the cross that one is assured is a Michelangelo original, made based on a man crucified and expiring - a fable that the view alone of this canvas proves to be false." See Richard's Description historique et critique de l'Italie, 4:175-6. François Maximilien Misson, earlier reporting the same, in his Voyage d'Italie (Paris, 1743), likewise states that the claim "reeks of fable, but they very much insist here on passing this off as a truth" (2:94). Young Michelangelo did dissect corpses awaiting burial - a practice approved by Niccolò Bichiellini, the prior of Santo Spirito in Florence - for training purposes. See George Bull, Michelangelo: A Biography (New York: St Martin's Press, 1995), 25-6; and Martin Gayford, Michelangelo: His Epic Life (London: Penguin, 2013), 152-4 and 261-2. Michelangelo would retain his interest in anatomy and dissection, and he was far from the only Renaissance artist to hone his skills in accurate representation in this manner.

170 Lucretius warns of the love's disturbance and recommends draining off desire by visiting prostitutes in the following terms: "it is fitting to flee from images, to scare away what feeds love, to turn the mind in other directions, to cast the collected liquid into any body, and not to retain it, being wrapped once for all in the love of one, nor to cherish care and certain pain for 
yourself. For the sore quickens and becomes inveterate by feeding, daily the madness takes on and the tribulation grows heavier, if you do not confuse the first wounds by new blows, and cure them in time while fresh by wandering with Venus light-o'-love [volgivagaque vagus Venere], or turn your thoughts in some other direction." See Lucretius, De Rerum Natura, trans. W.H.D. Rouse, revised by Martin Ferguson Smith (Cambridge, MA: Harvard University Press, 1992), 358-9 [bk4, 11.1063-72].

171 Sade, Euvres, 3:834.

172 Ibid.

173 On the affaire d'Arcueil and Sade's depiction as a human vivisector, see Steintrager, Cruel Delight, 87-95. On the depiction of vivisection in Sade's licentious writings, see also van Sant, Eighteenth-Century Sensibility and the Novel, 72-8. On the medical and anatomical gaze in Sade, see David B. Morris, The Culture of Pain (Berkeley: University of California Press, 1991), esp. 225-8 and 233-4.

174 This is, in nuce, van Sant's argument, in her Eighteenth-Century Sensibility and the Novel, about Sade's rhetorical strategies and his elicitation of reader response (74-80).

175 Sade, Euvres, 3:591. Sade was aware of Mirabeau's output, and in this same digression in Juliette on libertine writings, the heroine, evidently the author's mouthpiece here, states that she does not consider even Mirabeau's licentious writings to be adequate: "he wanted to be a libertine, in order to be something, and he is and will nevertheless be nothing at all his entire life" (ibid.). A note with a cutting reference to Mirabeau's actions during the Revolution adds: "Not even a legislator assuredly; one of the best proofs of the delirium and madness that characterized, in France, the year 1789, is the ridiculous enthusiasm that this vile spy of the monarchy inspired. What idea remains today of this man, immoral and sorely lacking in wit? That of a scoundrel, a traitor, and an ignoramus" (ibid.).

Honoré-Gabriel Riqueti, Comte de Mirabeau, Le Rideau levé, ou L'Éducation de Laure (Cythera [spurious], 1786) was definitely published anonymously, although Mirabeau has been the attribution for ages - since the Revolution, at least - and this is pretty sure, although sometimes questioned. An easier to locate, modern edition will be found in Euvres érotiques de Mirabeau. L'Enfer de la Bibliothèque Nationale, vol. 1, ed. Charles Hirsch (Paris: Fayard, 1984).

176 Sade, Euvres, 3:591.

177 I have borrowed the expression from the title of Annie Le Brun's book-length introduction to Sade's complete works in the Jean-Jacques Pauvert edition: Soudain, un bloc d'abîme, Sade: Introduction aux æeuvres complètes (Paris: Pauvert, 1986).

178 Sade, Euvres, 3:862.

179 Richard, Description historique et critique, 1:ix.

180 Diderot, Euvres esthétiques, 532. Michael Fried discusses this passage in Absorption and Theatricality: Painting and the Beholder in the Age of Diderot (Berkeley: University of California Press, 1980), 80-1. See also Michel Delon, "La beauté du crime," Europe 661 (1984): 73-83.

181 Sade, Euvres, 2:251. Sade's source on Gilles de Rais in the Italian manuscript is Claude Villaret, Histoire de France, Depuis l'établissement de la Monarchie, jusqu'au regne de Louis XIV (Paris, 1767), 15:294. His reading on the topic clearly continued, and in Justine, Sade refers the curious reader to "l'histoire de Bretagne de Dom Lobineau," a reference to GuyAlexis Lobineau's Histoire de Bretagne (Paris, 1707), which discusses Gilles de Rais's life and crimes (1:614-17). In La Nouvelle Justine, Sade adds a longer note on this figure and slightly - tellingly - expands Justine's outraged exclamation so that murder acts on the monks 
as an irritation of "both their nerves and their perfidious imagination," just as it was for Gilles de Rais a sort of jouissance (Sade, Euvres, 2:654-5).

182 Sade, Euvres, 3:428.

183 Ibid., 3:863.

184 Ibid.

185 Johann Burchard's account will be found in his Specimen Historice Arcance sive Anecdotce de Vita Alexandri VI Papae (Hanover, 1696), 77-82; Jean-Baptiste de Boyer, Marquis d'Argens's retelling is in his Histoire de l'esprit humain ou mémoires secrets et universels de la république des lettres (Berlin, 1767), 7:277-8.

186 Sade, Euvres, 3:868. Sade attempted to procure a private audience with Pius VI via a new friend in Rome, Cardinal de Bernis (whom Sade would also put into action in Juliette, not without some justification), but he apparently failed in this endeavour. See Gray, At Home with the Marquis de Sade, 170-1.

187 See Anon. [Gervaise de la Touche?], Histoire de Dom Bougre, Portier de Chartreux, in Euvres anonymes du XVIII e siècle (I) (Paris: Fayard, 1985), $172 \mathrm{ff}$.

188 For the original Latin and a modern English translation of Tiberius's debaucheries on Capri, see Suetonius, Lives of the Caesars, trans. J.C. Rolfe, revised by Donna W. Hurley (Cambridge, MA: Harvard University Press, 1997), 1:370-5.

189 As McMorran and Wynn note, in their translation and edition of the Les 120 journées de Sodome, the Chateau Silling is mysteriously moved from Switzerland, its initial location as indicated in the text, to Germany and the Black Forest (403).

190 See Suetonius, Lives of the Caesars, trans. J.C. Rolfe and revised by Donna W. Hurley (Cambridge, MA: Harvard University Press, 1997), 1:372-5.

191 Juvenal and Persius, Juvenal and Persius, trans. Susanna Morton Braund (Cambridge, MA: Harvard University Press, 2004), 245.

192 Sade, Euvres, 3:38.

193 Ibid., 3:853.

194 Sade visits the tomb of Andrew in Naples and reads of Joanna in Pietro Giannone, Histoire civile du royaume de Naples (The Hague, 1742), 3:296-301.

$195 \mathrm{He}$ will add to his arsenal other nations and races - e.g., Zinga a cruel Angolan queen and Zoë a wicked Chinese empress - but the Italian models, both ancient and modern, will retain crucial spots in Sade's pantheon.

196 According to Lucian's account of Praxiteles's celebrated sculpture. See Lucian, trans. A.M. Harmon (Cambridge, MA: Harvard University Press, 1925), 4:264-7.

197 Sade, Euvres, 2:1070.

198 Andrea Dworkin, in her Pornography: Men Possessing Women (New York: Perigree, 1981), makes the strongest case against the author and the man, dismissing - not unreasonably - the claims of "Sade's literary friends," who would find a positive model of freedom in Juliette (94). For Dworkin, Sade merely reveals what she characterizes as the violent core of pornography: "In Sade, the authentic equation is revealed: the power of the pornographer is the power of the rapist/batterer is the power of the man" (100). Many feminists, from Simone de Beauvoir to Jane Gallop, however, have argued for the value of reading Sade, which is not to say that they endorse his views (although they often do reveal an ambivalent appreciation of his writings). See, e.g., Simone de Beauvoir, “Must We Burn Sade?" in Sade, The 120 Days of Sodom and Other Writings, 3-64; and Jane Gallop, Feminism and Psychoanalysis: The Daughter's Seduction (London: Macmillan, 1982), 82-91. For the moralist's position on banning Sade, see Roger Shattuck, Forbidden Knowledge: From Prometheus to Pornography (New York: St Martin's Press, 1996), 283-99. 
199 In Wainhouse and Seaver's foreword to The 120 Days of Sodom and Other Writings, e.g., we find implied, clearly enough, an identification between the author and his character Justine: "The life of the Marquis de Sade was an incredible series of misfortunes, and what is perhaps most incredible of all was his capacity to withstand them" (x). They subsequently spell out this identification when they characterize Justine as Sade's "spiritual autobiography" (xi).

200 Roland Barthes, in his Sade/Fourier/Loyola, trans. Richard Miller (Baltimore: Johns Hopkins University Press, 1997), somewhat offhandedly remarks that "no one ever calls Sade a picaresque novelist (one of the rare ones in French literature)" (149). Barthes adds by way of explanation: "The apparent reason for this 'oversight' is that the Sadian adventurer (Juliette, Justine) is always traversing one sole adventure, and this adventure is vulgar" (ibid.). I consider Barthes's assessment overstated, yet it is probably true that the picaresque aspects of Sade's novels have been underappreciated.

201 François-Thomas-Marie de Baculard d'Arnaud, Anne Bell, Histoire angloise (Yverdon, 1770), 52. Baculard borrowed the name of his lamentable heroine - a noble, she falls for a commoner, becomes pregnant, contracts a secret marriage, has a child, is widowed, and so forth but hardly the plot from a real English incident and court case that had scandalized in 1760. Ann Bell or Sharpe was a London prostitute who most likely died of complications from stab wounds and lacerations about the anus received in a bagnio. The accused, an aristocrat, was acquitted. See Dan Cruickshank, The Secret History of Georgian London (London: Windmill Books, 2010), 413-35.

202 Ibid.

203 Sade, Euvres complètes du marquis de Sade (Paris: Pauvert, 1988), 10:73.

204 Ibid.

205 Ann Radcliffe, The Italian [1797], ed. Frederick Garber, revised with an introduction and notes by Nick Groom (Oxford: Oxford University Press, 2017), 12.

206 Sade, Euvres, 2:778.

207 Ibid., 3:1100.

208 See Hauc, Ange Goudar, 143; Maurice Lever's introduction to Sade, Voyage d'Italie, 1:14.

209 Sade, Euvres, 3:1101.

210 Ibid., 3:1102.

211 Ibid. 
This page intentionally left blank 